UNIVERSIDADE DE SÃO PAULO

INSTITUTO DE PSICOLOGIA

LIANA GAMA DO VALE

\title{
DESENVOLVIMENTO MORAL:
}

\section{A GENEROSIDADE RELACIONADA À JUSTIÇA E À GRATIDÃO SOB A ÓTICA DAS CRIANÇAS}




\section{DESENVOLVIMENTO MORAL:}

\section{A GENEROSIDADE RELACIONADA À JUSTIÇA E À GRATIDÃO SOB A ÓTICA DAS CRIANÇAS}

(Versão original)

Tese apresentada ao Instituto de Psicologia da Universidade de São Paulo como parte dos requisitos para obtenção do grau de Doutor em Psicologia.

Área de concentração: Psicologia Escolar e do Desenvolvimento Humano

Orientador: Prof. Dr. Yves Joel Jean Marie Rodolphe de La Taille 
Nome: Vale, Liana Gama do

Título: Desenvolvimento moral: a generosidade relacionada à justiça e à gratidão sob a ótica das crianças

Tese apresentada ao Instituto de Psicologia da Universidade de São Paulo como parte dos requisitos para obtenção do grau de Doutor em Psicologia.

Aprovado em:

Banca Examinadora

Prof. Dr.

Instituição:

Assinatura:

Prof. Dr.

Instituição:

Assinatura:

Prof. Dr

Instituição:

Assinatura:

Prof. Dr.

Instituição:

Assinatura:

Prof. Dr.

Instituição:

Assinatura: 


\section{AGRADECIMENTOS}

A Daniel Augusto Siquara, marido e companheiro de todas as horas, pela aposta e incentivo constantes ao longo da minha trajetória profissional. Obrigada pelas tiradas espirituosas nos momentos intricados deste doutorado e por sempre me fazer acreditar que "no final, tudo vai dar certo". É sempre uma delícia confirmar a sua "tese" e poder comemorá-la com você!

Aos meus pais, Amélia e Gustavo, pelo amor incondicional e pela preciosa dedicação à minha formação pessoal e profissional. Às minhas irmãs, Joana e Júlia, pelo carinho e pela torcida de sempre. A saudade que sinto de vocês, embora feliz, não basta. Estou sempre contando os dias para revê-los.

Ao professor Sávio Silveira de Queiroz, por ter me apresentado a teoria de Piaget de forma tão competente no início do curso de Psicologia e, concedendo-me a oportunidade de trabalhar ao seu lado, ter me permitido aprimorar meus conhecimentos a respeito. Sua aposta na minha capacidade profissional, desde quando eu ensaiava meus primeiros passos, foi fundamental para que eu seguisse adiante e chegasse até aqui.

À professora Heloisa Moulin de Alencar, por ter me apresentado de forma brilhante a obra de Piaget $O$ juízo moral na criança e tantos outros textos afins no final do curso de Psicologia, despertando o meu interesse pelo estudo da moralidade. Foi esse interesse que me conduziu ao mestrado, onde tive o privilégio de tê-la como orientadora. Obrigada pela cuidadosa dedicação no início da minha caminhada como pesquisadora e por todas as colaborações que me concedeu durante este doutorado.

Ao professor Yves de La Taille, pelas inestimáveis contribuições ao meu percurso acadêmico. Em primeiro lugar, obrigada pela sua obra, que se destaca no campo de pesquisas dedicadas à moralidade não só pela originalidade de suas reflexões, mas pela seriedade e clareza com que apresenta suas ideias. Seus textos sempre foram para mim exemplos de como escrever bem. Em segundo lugar, obrigada pelas suas aulas, onde tanto pude aprender com a elegância de seu discurso e seu afável senso de humor. E, por fim, obrigada pelas suas orientações, onde me aperfeiçoei como pesquisadora com a objetividade e a precisão de suas explanações relativas a este trabalho. Saiba que, em todas as páginas desta tese, há colaborações advindas do seu valioso trabalho, seja dos textos que escreveu, das aulas que ministrou ou das orientações que me concedeu. E que honra a minha ter podido lhe conhecer como autor, professor e orientador! 
Às professoras Luciene Regina Paulino Tognetta e Maria Thereza Costa Coelho de Souza, pelas sugestões referentes a esta pesquisa apresentadas no Exame de Qualificação.

À professora Lia Beatriz de Lucca Freitas, por ter me facilitado o acesso às suas produções científicas, muitas delas de grande valia para este trabalho.

A Cláudia Patrocinio Pedroza Canal, que sempre foi, fazendo uso de suas próprias palavras, "afetiva e cognitivamente", uma grande colaboradora na minha trajetória acadêmica.

Às colegas do mestrado que se tornaram grandes amigas: Mirian Beccheri Cortez, Luciana Souza Borges e Alline Nunes Andrade.

Às "Anas Paulas", pelo companheirismo nessa jornada e pelas deliciosas conversas, que tornavam a "volta pra casa" menos cansativa. Ana Paula Sthel Caiado, amiga desde os tempos da graduação, cujo doutorado na USP nos aproximou ainda mais. E Ana Paula Martins Cazeiro, que, com tantas felizes coincidências, não nos restava outra relação senão a de amizade.

Às colegas da USP, especialmente a Dinah Carolina Borges Crespo, pelo carinho e acolhida na grande "Sampa".

À direção, coordenação pedagógica e professores da escola onde realizei a coleta de dados, aos alunos que participaram desta pesquisa e aos seus pais, por terem autorizado essa participação.

À CAPES, pelo apoio financeiro. 


\section{RESUMO}

Vale, L. G. (2012). Desenvolvimento moral: a generosidade relacionada à justiça e à gratidão sob a ótica das crianças. Tese de Doutorado, Instituto de Psicologia, Universidade de São Paulo, São Paulo.

Neste trabalho, nos dedicamos ao estudo da generosidade, investigando, em um contexto psicogenético, os juízos morais das crianças relativos aos seguintes temas: a generosidade em contraposição à justiça (para consigo mesmo) e generosidade e gratidão. Participaram desta pesquisa 60 alunos de uma escola particular da cidade do Rio de Janeiro - RJ, com 6, 9 e 12 anos, igualmente divididos quanto ao sexo e à idade. Realizamos entrevistas individuais baseadas em histórias sobre os temas em questão. Dos resultados encontrados, destacamos que, diante de um conflito entre a generosidade e a justiça (para consigo mesmo), os juízos das crianças de 6 anos nos remetem mais à generosidade, e os critérios utilizados pelos mais velhos, para hierarquizar as duas dimensões morais, estão atrelados a uma noção geral de justiça. No que diz respeito ao tema da generosidade e gratidão, verificamos que a maioria das crianças de todas as idades pesquisadas não atribui obrigatoriedade ao agradecimento e/ ou à retribuição a uma manifestação de generosidade. Embora desprovida de obrigatoriedade, a retribuição é indicada e admirada, nas suas variadas formas, pelos participantes. Essa indicação e admiração, todavia, não fazem da retribuição um critério que os leve a agir generosamente, nos mostrando, assim, sinais de autonomia nos juízos relacionados à generosidade desde a mais tenra infância. Ao indicarem um agradecimento ou uma retribuição à ação generosa, as crianças mais novas ora ressaltam o aspecto concreto da recompensa, ora se referem à materialidade das regras da polidez, ainda exteriores à consciência. Dessa forma, ora visualizamos a incipiência de suas ferramentas intelectuais, ora nos deparamos com características da heteronomia infantil em seus juízos sobre o tema. A recompensa com uma ação concreta predomina nas sugestões espontâneas de agradecimento e/ ou retribuição das crianças de 9 e 12 anos, e a demonstração verbal de reconhecimento prevalece entre os mais velhos quando comparada exclusivamente à recompensa material. Tal reconhecimento pressupõe uma avaliação das intenções daquele que agiu generosamente, imprescindível na manifestação da gratidão. Como as crianças mais novas ainda conferem maior importância aos efeitos de um ato do que à intenção de seu autor, parece-nos válido afirmar que não é a gratidão propriamente dita que comparece em seus discursos, mas uma concepção mais elementar da virtude, o que nos leva a admitir um desenvolvimento da mesma ao longo da infância. Nossos resultados também confirmam a íntima relação do sentimento de simpatia com a generosidade, já apontada por outras pesquisas da área. Uma comoção com o sofrimento alheio comparece nas argumentações das crianças que decidiram pela ação generosa para com o outro. Com porcentagens altas em todas as faixas etárias pesquisadas, esse argumento predomina na menor idade e decresce nas idades seguintes. Tal resultado nos mostra que é mesmo a simpatia que inspira as crianças pequenas a decidirem pela manifestação da virtude. Essa sensibilidade para com outrem também interfere nos juízos dos participantes mais velhos, mas, no transcurso do desenvolvimento, princípios de reciprocidade e justiça também passam a regular decisões que culminam na generosidade.

Palavras-chave: desenvolvimento moral; virtudes; generosidade; justiça; gratidão. 


\begin{abstract}
Vale, L. G. (2012). Moral development: generosity related to justice and gratitude from the viewpoint of children. Tese de Doutorado, Instituto de Psicologia, Universidade de São Paulo, São Paulo.
\end{abstract}

In this work, we dedicate ourselves to the study of generosity, investigating, in a psychogenetic context, children's moral judgment relating to the following themes: generosity as opposed to justice (for oneself) and generosity and gratitude. Participated in this survey, 60 pupils from a private school in the city of Rio de Janeiro - RJ, with 6, 9 and 12 years of age, equally divided as to sex and age. We conducted one-on-one interviews based on stories about the themes in question. Of the results found, we highlighted that, faced with a conflict between generosity and justice (to oneself), the judgment of 6 year old children refer to generosity, and the criteria used by the older ones, to organize into a hierarchy the two moral dimensions, are tied to a general notion of justice. On the subject of generosity and gratitude, we find that the majority of children of all ages surveyed do not assign an obligation as to what concerns gratitude and/or consideration as a reciprocation to an expression of generosity. Although devoid of obligation, reciprocation is indicated and admired, in its various forms, by the participants. This indication and admiration, however, does not make reciprocation a criterion that makes them act generously, thus showing us signs of autonomy in judgments related to generosity from an early childhood. When indicating an appreciation or a reciprocation to the generous action, younger children either point out the specific aspects of reward, or refer to the materiality of the rules of politeness, still exterior from their consciousness. In this way, we see how incipient are their intellectual tools, or we are faced with characteristics of infant heteronomy on their judgment of the theme. Rewards with a concrete action predominates in spontaneous suggestions of gratitude and/or reciprocation in children of 9 and 12 years old, and a verbal demonstration of gratitude prevails among the elderly when compared exclusively to material reward. Such recognition requires an evaluation of the intentions of that who acted generously, essential in the expressions of gratitude. As younger children still attach great importance to the effects of an act than to the intention of its author, it is valid to say that it is not gratitude itself that appears on their speech, but a more elementary conception of virtue, which leads us to admit its development throughout childhood. Our results also confirm the close relationship of the feeling of sympathy with generosity, already pointed out by other researches in this area. A commotion with the suffering of others appears in the arguments of children who decided for the generous action with each other. With high percentages in all age groups surveyed, this argument predominates in the lowest age and decreases in the following ages. This result shows that it is sympathy that inspires the young children to decide for the manifestation of virtue. This sensitivity to others also interferes in the judgment of the older participants, but, in the course of the development, principles of reciprocity and justice also regulate decisions that culminate in generosity.

Key-words: moral development; virtues; generosity; justice; gratitude 


\section{LISTA DE TABELAS}

Tabela 1 Generosidade em contraposição à justiça (para consigo mesmo) história 1: distribuição conforme a idade das justificativas dos participantes que decidiram não ajudar o outro.

Tabela 2 Generosidade em contraposição à justiça (para consigo mesmo) história 1: distribuição conforme a idade das justificativas dos participantes que decidiram ajudar o outro.

Tabela 3 Generosidade em contraposição à justiça (para consigo mesmo) história 2: distribuição conforme a idade das justificativas dos participantes que decidiram ajudar o outro.

Tabela 4 Tipos de reação à generosidade: distribuição das respostas dos participantes conforme a idade.

Tabela 5 Tipos de recompensa: distribuição conforme a idade das respostas dos participantes que indicaram a recompensa como reação à generosidade.

Tabela 6 Agradecimento e/ ou retribuição à generosidade: distribuição das justificativas dos participantes conforme a idade.

Tabela 7 Obrigatoriedade da retribuição a uma ação generosa: distribuição conforme a idade das justificativas dos participantes que responderam não..

Tabela 8 Por que as personagens que retribuíram a uma ação generosa agiram bem? - distribuição das justificativas dos participantes conforme a idade

Tabela 9 Por que um tipo de retribuição não é mais valorizado do que o outro? - distribuição conforme a idade das justificativas dos participantes que responderam não...

Tabela 10 Distribuição conforme a idade das justificativas dos participantes que decidiram pela demonstração verbal de reconhecimento. 
Tabela 11 Influência da possibilidade de retribuição na manifestação de generosidade: distribuição conforme a idade das justificativas dos participantes que decidiram pela generosidade para com ambas as personagens.

Tabela 12 Influência da possibilidade de retribuição na intensidade da ação generosa: distribuição conforme a idade das justificativas dos participantes que decidiram pela divisão igual...................................

Tabela A1 Distribuição dos participantes da pesquisa de acordo com idade e sexo. 


\section{LISTA DE FIGURAS}

Figura 1 Generosidade em contraposição à justiça (para consigo mesmo) história 1: comparação das respostas dos participantes conforme a idade.

Figura 2 Generosidade em contraposição à justiça (para consigo mesmo) história 2: comparação das respostas dos participantes conforme a idade.

Figura 3 Obrigatoriedade do agradecimento e/ ou retribuição à generosidade: comparação das respostas dos participantes conforme a idade

Figura 4 Um tipo de retribuição é mais valorizado do que o outro? comparação das respostas dos participantes conforme a idade

Figura 5 Tipo de retribuição mais valorizado pelos participantes que responderam sim: comparação das respostas conforme a idade...........

Figura 6 Influência da possibilidade de retribuição na manifestação de generosidade: comparação das respostas dos participantes conforme a idade

Figura 7 Influência da possibilidade de retribuição na intensidade da ação generosa: distribuição conforme a idade das respostas dos participantes que decidiram pela generosidade para com ambas as personagens.

Figura 8 Pesquisas que abordam a generosidade em um contexto psicogenético. 


\section{LISTA DE SIGLAS}

USP - Universidade de São Paulo

CAPES - Coordenação de Aperfeiçoamento de Pessoal de Nível Superior

PCNs - Parâmetros Curriculares Nacionais

CEPH - Comitê de Ética em Pesquisa com Seres Humanos

IPUSP - Instituto de Psicologia da Universidade de São Paulo

BVS-PSI - Biblioteca Virtual de Saúde em Psicologia 


\section{SUMÁRIO}

1. INTRODUÇÃO.

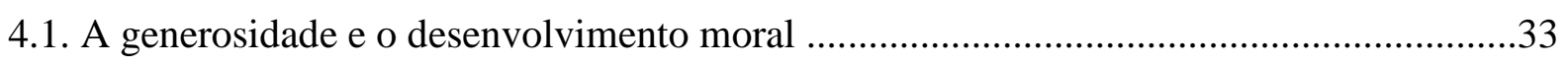

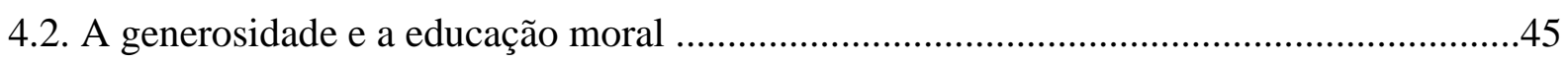

5. ESTUDO 1: A GENEROSIDADE EM CONTRAPOSIÇÃO À JUSTIÇA (PARA

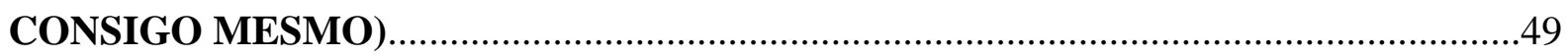

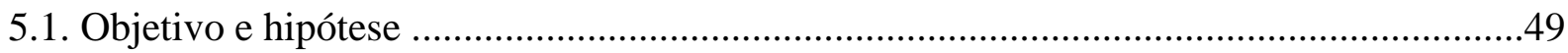

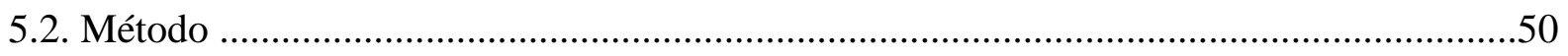

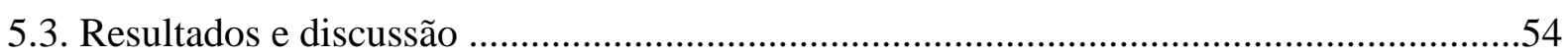

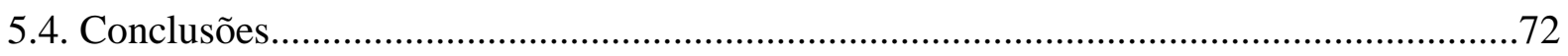

6. ESTUDO 2: GENEROSIDADE E GRATIDÃO ...................................................... 75

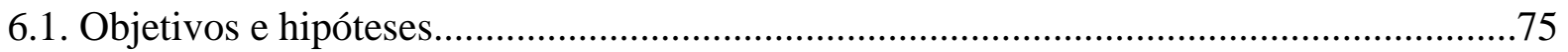

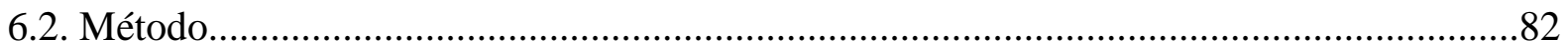

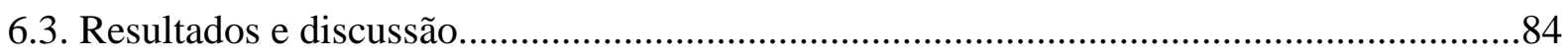

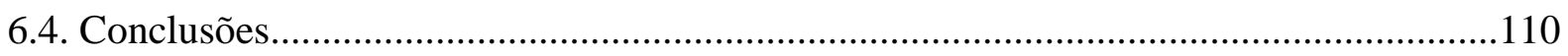

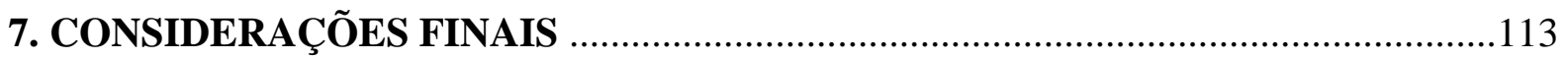

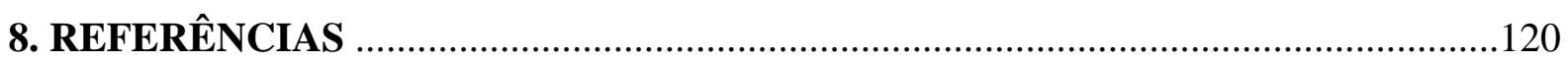

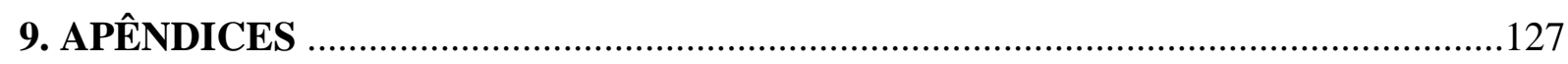

Apêndice A - Parecer do Comitê de Ética em Pesquisa com Seres Humanos........................127

Apêndice B - Modelo do pedido de autorização para a escola.............................................129

Apêndice C - Modelo do termo de consentimento dos pais ou responsáveis legais .............133

Apêndice D - Protocolos das entrevistas (em CD digitalizado). 


\section{INTRODUÇÃO}

Visando contribuir para a expansão do campo de pesquisas sobre a moral, dedicamos nossa dissertação de mestrado (Vale, 2006) ao estudo da generosidade. Investigamos, em um contexto psicogenético, os juízos de crianças e adolescentes sobre essa virtude, averiguando o seu lugar no universo moral dos participantes. Para tanto, realizamos entrevistas individuais, utilizando histórias que versam sobre os seguintes temas: a generosidade em contraposição à satisfação do próprio interesse; a generosidade em contraposição à obediência à autoridade; generosidade para com amigo, desconhecido e inimigo; ausência de generosidade e punição.

No doutorado, nos propomos a dar continuidade a esse trabalho e investigar outros aspectos atinentes à generosidade, procurando ampliar, assim, o quadro geral de estudos sobre a gênese dessa virtude na criança. Com base em nossas leituras e pesquisas, ainda restam, a nosso ver, dois grandes temas relativos à generosidade que merecem ser pesquisados para compreendermos de forma mais abrangente as relações entre a virtude e o desenvolvimento moral infantil. O primeiro deles diz respeito a uma contraposição entre a generosidade e a justiça (para consigo mesmo), e o segundo se refere à retribuição à ação generosa, que nos remete, em parte, à virtude gratidão. Comentaremos de forma mais detalhada nossa pesquisa nas páginas que se seguem. De imediato, conheçamos do que tratam os capítulos que compõem este trabalho.

No próximo capítulo, apresentamos um panorama geral sobre o estudo da moralidade. Em seguida, nos dedicamos ao tema das virtudes e a sua possível inserção no campo da moral. A partir das definições de moral e ética adotadas aqui, mostramos a importância de estudos psicológicos de virtudes morais. No capítulo seguinte, discorremos sobre a generosidade. Destacamos algumas características dessa virtude, procurando articulá-la com outros valores como justiça, solidariedade e gratidão. Na sequência, procuramos mostrar, a partir de uma perspectiva genética, o que nos leva a eleger a generosidade como objeto de investigação da psicologia do desenvolvimento. Para tanto, recorremos a autores clássicos do campo da moralidade, como Kohlberg (1992), Gilligan (1982) e, principalmente, Piaget (1932/1994). Nessa seção, também apresentamos os principais resultados de nossa dissertação de mestrado e outros dados de pesquisas sobre a generosidade que trazem contribuições para esta investigação. Finalizamos a revisão teórica desta tese mostrando a relevância de um estudo psicológico da generosidade para o campo da educação moral.

Os dois capítulos seguintes são dedicados à pesquisa que aqui realizamos, dividida em dois estudos. O primeiro deles trata da generosidade em contraposição à justiça (para consigo 
mesmo), e o segundo, da generosidade e gratidão. Discorremos sobre cada tema de investigação separadamente, apresentando os objetivos, as hipóteses, o método, os resultados e as discussões correspondentes.

No oitavo e último capítulo, apresentamos uma articulação entre as principais pesquisas encontradas na literatura da área, nossos estudos do mestrado e as contribuições inéditas desta tese, buscando, dessa forma, oferecer ao leitor uma espécie de estado da arte dos estudos sobre a gênese da generosidade na criança. 


\section{O ESTUDO DA MORALIDADE}

A moralidade foi objeto de estudo dos filósofos antigos, em cujos trabalhos podem ser encontradas as origens das concepções sobre a moral. Nesse campo do conhecimento, destacamos os escritos do filósofo alemão Emmanuel Kant (1785/1980), que exerceram forte influência nas reflexões atinentes à moralidade na área da psicologia.

De acordo com Kant (1785/1980), agir moralmente é agir incondicionalmente por dever, legitimando e respeitando as leis morais. A motivação para legitimá-las e respeitá-las, segundo o autor, deve ser puramente racional, logo, inclinações pessoais e traduções da sensibilidade como o medo, o prazer e o desejo não conferem valor moral algum à ação. Nas palavras do filósofo: "não é nem o medo nem a inclinação, mas tão somente o respeito à lei que constitui o móbil que pode dar à ação um valor moral” (p. 144). Para Kant, a moral é composta por imperativos categóricos, absolutamente necessários e não contingentes, cujo valor não depende das consequências dos atos, sejam elas externas ou internas, imediatas ou não. A verdadeira moral, de acordo com o autor, é baseada no dever de agir segundo princípios universais: “Age apenas segundo uma máxima tal que possas querer que ela se torne lei universal" (p. 129), preconiza um de seus imperativos categóricos. Nesse sentido, se um adolescente, por exemplo, opta por não agredir um colega que o provocara no recreio escolar porque lembra que, caso o faça, irá para a coordenação, não há aí, segundo Kant, valor moral algum, já que o aluno age dessa forma movido por um sentimento de medo de um possível castigo. Haveria valor moral, contudo, se o adolescente optasse por não agredir o colega, entendendo que a agressão a outrem jamais poderia ser uma "lei universal" e, portanto, um imperativo categórico.

Na década de 20, o pai da psicanálise, Sigmund Freud (1923/1976), menciona o imperativo categórico de Kant (1785/1980) ao apresentar sua hipótese a respeito da existência de uma instância psíquica responsável pela consciência moral: o superego, definido pelo autor como o herdeiro do complexo de Édipo. Segundo Freud, com o declínio do complexo de Édipo, a criança renuncia à satisfação de seus desejos edipianos marcados de interdição e se identifica com o pai (ou a mãe, no caso da menina), interiorizando, dessa forma, os interditos parentais. Desse processo decorre a formação do superego, que encarna a lei e proíbe a sua transgressão, desempenhando, assim, o papel de um juiz que exerce um controle moral das ações. "O superego reteve características essenciais das pessoas introjetadas - a sua força, sua 
severidade, a sua inclinação a supervisar e punir.... O Imperativo Categórico de Kant é, assim, o herdeiro direto do complexo de Édipo" (Freud, 1924/1976, pp. 208 e 209).

Convém ressaltar que, embora Freud (1923/1976) admita a existência de uma moral humana e compare os ditames do superego ao imperativo categórico kantiano, o pai da psicanálise não atribui a fonte do dever exclusivamente à razão como o fez Kant (1785/1980). Ao abordar a moral, Freud se remete ao segmento nuclear de sua obra: o inconsciente. A partir de suas observações clínicas, o autor defende a tese de que “(...) o psiquismo não é redutível ao consciente e que certos 'conteúdos' só se tornam acessíveis à consciência depois de superadas certas resistências (...)" (Laplanche \& Pontalis, 2001, p. 236). E, nessa instância psíquica responsável pelas obrigações oriundas da moralidade, Freud reconhece uma origem e uma parte inconscientes. O superego, portanto, além de ser o responsável pelo pensar e agir morais, pode operar de forma inconsciente. Destacamos aqui o que La Taille (2007) chamou da radical inovação da teoria moral freudiana: “(...) é justamente fazer comparecer forças inconscientes para explicar o fenômeno do dever" (p. 18).

Embora reconheçamos a enorme contribuição das descobertas de Freud para o estudo da moralidade, vale mencionar que a moral não fora o principal objeto de suas pesquisas e reflexões. Considerando que nosso trabalho se situa no campo da psicologia moral, não nos estenderemos na apresentação de sua teoria. Ocupemo-nos, agora, dos autores que se dedicaram à elucidação dos processos mentais que presidem o desenvolvimento moral, a saber: Jean Piaget (1932/1994) e Lawrence Kohlberg (1992).

Comecemos com os estudos do epistemólogo suíço Jean Piaget (1932/1994), que também fez uso das concepções de Kant (1785/1980) ao elaborar sua teoria sobre o desenvolvimento do juízo moral na criança. Piaget é considerado o pioneiro nas pesquisas sobre a moralidade infantil na área da psicologia. Embora o autor não tenha prosseguido seus estudos sobre o tema, sua obra intitulada $O$ juízo moral na criança, publicada originalmente em 1932, tornouse um clássico da literatura psicológica contemporânea e uma referência indispensável para pesquisadores da área da moralidade.

Partindo da ideia de que a moralidade infantil esclarece, de certa forma, a moralidade humana, Piaget (1932/1994) realizou entrevistas clínicas com crianças de 5 a 12 anos sobre jogos de regras e dilemas morais que refletiam situações do cotidiano infantil como: dano material, roubo, mentira, punição, entre outras. Nessas entrevistas, as crianças desempenhavam o papel de pequenos juízes, cuja tarefa consistia em tomar uma posição sobre as diversas situações apresentadas. Empregando esse método, Piaget tinha acesso ao juízo moral de cada entrevistado, e não à sua ação ou sentimento. Nas primeiras páginas de 
sua obra sobre o tema, o autor adverte o leitor a esse respeito, e a mesma ressalva pode ser encontrada em sua discussão sobre o método empregado: “(...) procuremos estudar não o ato, mas simplesmente o julgamento do valor moral. Em outras palavras, analisemos não as decisões da criança nem mesmo as lembranças de suas ações, mas a maneira pela qual ela avalia esta ou aquela conduta" (p. 95).

Os resultados das pesquisas levaram Piaget (1932/1994) a sustentar a tese de que há um desenvolvimento do juízo moral, e que esse desenvolvimento segue um caminho necessário em direção à autonomia, caracterizada pela reciprocidade universal, na qual todo e qualquer ser humano tem lugar, independentemente da posição social que ocupa. Nas palavras do autor: "A autonomia só aparece com a reciprocidade, quando o respeito mútuo é bastante forte para que o indivíduo experimente interiormente a necessidade de tratar os outros como gostaria de ser tratado" (p. 155). Piaget destaca, ainda, que a moral não é meramente interiorizada pela criança, mas é produto de um processo de construção, que passa por fases sucessivas e hierarquizadas, a partir das interações da criança com o meio social e de processos psíquicos individuais de auto-regulação (ou auto-organização). O autor distingue, assim, três fases do desenvolvimento do juízo moral: a anomia, a heteronomia e a autonomia.

Antes dos 4 anos em média, as regras derivadas da moral estão associadas a regularidades espontâneas ou hábitos de conduta, e não a valores como o bem e o mal, o certo e o errado. A anomia “(...) corresponde ao estágio do desenvolvimento durante o qual a criança ainda não adentrou o universo moral" (La Taille, 2006b, p. 97). O ingresso nesse universo só ocorre na segunda fase do desenvolvimento: a heteronomia.

A moral heterônoma traduz-se pelo realismo moral, que, segundo Piaget (1932/1994), comporta pelo menos três características. A primeira delas consiste em considerar moralmente correto todo ato que revela uma obediência às regras impostas pela figura de autoridade. Aqui, tais regras não são elaboradas nem mesmo compreendidas pela criança, já que esta se limita a segui-las. De tal fato emana a segunda característica: as regras são interpretadas ao pé da letra, e não no seu espírito. E a terceira característica é a importância dada à responsabilidade objetiva do ato, ou seja, a gravidade da ação é considerada moralmente mais relevante que a intenção do autor do delito.

De acordo com Piaget (1932/1994), o realismo moral é produto do pensamento espontâneo infantil e das relações de coação social, cujo protótipo é, geralmente, a relação hierárquica de mandamentos e obediência estabelecida entre a criança e seus pais. Nesse tipo de relação, há um predomínio do respeito unilateral (não recíproco), que é condição necessária, porém não suficiente, para a promoção do desenvolvimento moral na criança. 
Piaget (1932/1994) menciona, ainda, que, na heteronomia, o respeito da criança às regras morais decorre da fusão entre os sentimentos de medo e amor. "Ora, é justamente pelo fato de os pais inspirarem, ao mesmo tempo, medo e amor, que eles inspiram respeito" (La Taille, 2006b, p. 109). A pequena maturidade intelectual da criança dessa fase ainda não lhe permite uma real avaliação do valor das regras, logo, a criança respeita as regras porque respeita as pessoas que lhes impuseram essas regras, e respeita tais pessoas porque elas lhes inspiram, simultaneamente, medo e amor. O medo provém da perspectiva de uma possível perda do amor dos pais e das inevitáveis e desagradáveis punições. O medo deriva também do simples fato de a criança pequena se ver fraca diante dos pais, considerados grandes, fortes e poderosos. $\mathrm{O}$ amor, por sua vez, consiste no apego e na admiração naturais que a criança tem pelos seus pais ou pelas pessoas significativas para ela. O amor e o medo são, portanto, os dois sentimentos responsáveis pela obediência voluntária heterônoma, que consiste na primeira expressão do dever (La Taille, 2002a). Tal dever, segundo La Taille (2002a), não deixa de ser um primeiro passo em direção ao dever moral propriamente dito, que ocorrerá na terceira e última fase do desenvolvimento moral: a autonomia.

Por volta dos 9 anos de idade, se o convívio social permitir relações simétricas de cooperação, a criança começa a apresentar sinais de autonomia. Nas palavras de Piaget (1932/1994):

Se a criança (...) encontra com os irmãos e irmãs ou com seus amigos de brinquedo uma sociedade que desenvolve sua necessidade de cooperação e de simpatia mútua, criará em si uma moral de um novo tipo, moral da reciprocidade e não da obediência. Essa é a verdadeira moral da intenção e da responsabilidade subjetiva (p. 113).

$\mathrm{Na}$ autonomia, o respeito unilateral por uma figura de autoridade dá lugar ao respeito mútuo, fruto de uma igualdade entre os membros no convívio. Nessa fase, as regras não são apenas incorporadas, mas compreendidas e interpretadas a partir de princípios. A criança torna-se capaz de fazer suas próprias avaliações morais, de participar na elaboração das regras e de verificar se estas trazem benefícios para o grupo em que vive. Um ato moralmente correto passa a ser o que está de acordo com os princípios da reciprocidade e do respeito mútuo, e não mais o que revela uma obediência à ordem imposta pela autoridade. A criança começa a experimentar interiormente a necessidade de tratar o outro como gostaria de ser tratada. E essa moral da reciprocidade é, como diz Piaget (1932/1994), “(...) a verdadeira moral da intenção e da responsabilidade subjetiva" (p. 113), que predomina paulatinamente sobre a moral da responsabilidade objetiva. Agora, a intenção do autor de um delito tende a 
ser moralmente mais importante para a criança do que a qualidade ou a quantidade do dano causado.

No que diz respeito ao sentimento presente nessa última fase, Piaget (1932/1994) afirma:

O elemento quase material do medo, que intervém no respeito unilateral, desaparece então progressivamente em favor do medo totalmente moral de decair aos olhos do indivíduo respeitado: a necessidade de ser respeitado equilibra, por conseguinte, a de respeitar; e a reciprocidade que resulta dessa nova relação basta para aniquilar qualquer elemento de coação (p. 284).

É importante mencionar, ainda, que Piaget (1932/1994) dedicou parte de seu ensaio sobre a moralidade infantil ao estudo da justiça, a mais racional de todas as noções morais. Aqui, o autor também encontrou uma fase de heteronomia anterior a uma fase de autonomia. Abordaremos a seguir os dois aspectos investigados dessa noção: a justiça distributiva, caracterizada pela igualdade; e a justiça retributiva, definida pela proporcionalidade entre o ato e a sanção. A partir dos resultados encontrados em seus estudos, Piaget estabeleceu três grandes períodos no desenvolvimento da justiça na criança.

O primeiro período estende-se até por volta dos 7-8 anos de idade e "é caracterizado pela indiferenciação das noções do justo e do injusto com as noções de dever e de desobediência: é justo o que está de acordo com as ordens impostas pela autoridade adulta" (Piaget, 1932/1994, p. 236). Nesse período, quando a criança é colocada diante de um conflito entre a obediência e a igualdade, sua decisão é sempre a favor da obediência, o que deixa claro a primazia da autoridade sobre a justiça. Todavia, nas situações de justiça distributiva entre crianças que não envolvem conflito com uma figura de autoridade, a igualdade já aparece como uma necessidade. Nessa fase, a sanção constitui uma obrigação moral, e o valor da punição é medido pela sua severidade. Assim, no campo da justiça retributiva, a criança tende a optar pela sanção expiatória, cujo conteúdo não possui relação alguma com a natureza do delito.

O segundo período se inicia em torno dos 7-8 anos aproximadamente e é marcado pelo desenvolvimento progressivo da autonomia e pela primazia da igualdade sobre a autoridade. Aqui, o igualitarismo desenvolve-se e prevalece sobre qualquer outra preocupação. No que diz respeito à justiça retributiva, a criança considera justa apenas a sanção por reciprocidade, isto é, quando há relação entre a natureza da falta e o conteúdo da punição e uma proporcionalidade entre a gravidade daquela e o rigor desta.

O terceiro e último período tem início em torno dos 11-12 anos aproximadamente e é caracterizado pelo sentimento de equidade, que, segundo Piaget (1932/1994), “(...) é apenas um desenvolvimento do igualitarismo no sentido da relatividade: em lugar de procurar a 
igualdade na identidade, a criança não concebe mais os direitos iguais dos indivíduos, senão relativamente à situação particular de cada um" (p. 237). No campo da justiça distributiva, a criança não mais compreende a lei como igual para todos, mas considera as circunstâncias de cada pessoa. "Longe de levar ao privilégio, tal atitude conduz a tornar a igualdade mais efetiva do que era antes" (p. 238). Em relação à justiça retributiva, a criança passa a considerar as particularidades atenuantes de cada caso e, assim, não mais sugere a aplicação da mesma sanção para qualquer situação.

No que diz respeito às sanções por reciprocidade, vale acrescentar que Piaget (1932/1994) distingue alguns tipos que variam de acordo com a natureza do ato repreensível. Conheçamos rapidamente cada tipo relatado pelo autor.

O primeiro tipo é caracterizado pela ruptura do elo social, já que a criança que cometeu a falta é excluída, temporária ou permanentemente, de seu grupo. No segundo tipo, trata-se de fazer o autor do delito suportar as consequências de seu ato. Nesse caso, Piaget (1932/1994) afirma que a sanção é uma "consequência natural" da falta e ressalta: "(...) a sanção dita natural implica a reciprocidade, porque sempre existe a vontade do grupo ou do educador de fazer o culpado compreender que o elo de solidariedade está rompido" (p. 163). A terceira forma de punição por reciprocidade se resume na privação do culpado daquilo que foi mal usado. Para ilustrar esse terceiro caso, Piaget cita o exemplo de “(...) não mais emprestar à criança um livro que ela mesma manchou" (p. 163). No quarto tipo, são incluídas as sanções que consistem em fazer com aquele que cometeu a falta algo semelhante àquilo que ele fez. Piaget deixa claro que essa sanção só é legítima quando há uma preocupação em fazer a criança compreender o alcance de sua ação, e não "quando é apenas questão de devolver o mal com o mal” (p. 164). O quinto tipo mencionado pelo autor é a sanção restitutiva, que consiste em fazer com que a criança pague, substitua ou conserte um objeto que danificou. Piaget destaca, ainda, que as crianças mais velhas consideram, muitas vezes, a simples repreensão, não acompanhada de qualquer punição, mais eficaz que o castigo. Nesse caso, há uma tentativa de fazer o culpado compreender que rompeu o elo de solidariedade com seu ato.

Embora tenhamos mencionado as idades médias relacionadas a cada fase, urge ressaltar que não podemos marcar rigidamente a passagem da heteronomia para a autonomia. Piaget (1932/1994) ressalta que esses dois conceitos não nos remetem a estágios propriamente ditos, mas a tendências dominantes por meio das quais a criança pensa a moral. De acordo com o autor, traços de ambas as tendências podem, inclusive, ser encontrados, em determinado momento, na mesma criança. Nesse sentido, não podemos afirmar, por exemplo, que, a partir dos 9 anos de idade, uma criança deixa de ser heterônoma e passa a ser plenamente autônoma. 
Com base nas elaborações piagetianas, podemos dizer apenas que, a partir dessa idade (aproximadamente), se as interações com o meio social forem favoráveis, as concepções infantis a respeito da moral começam a mudar, o que não significa que essa nova forma de pensar a moral substitua inteiramente a anterior.

Assumindo os pressupostos básicos de Piaget (1932/1994), o psicólogo norte-americano Lawrence Kohlberg (1992) elaborou um modelo psicogenético de desenvolvimento moral, contribuindo para a consolidação desse campo de conhecimento.

Kohlberg (1992), como Piaget (1932/1994), estudou o juízo moral e, para tanto, também fez uso de entrevistas clínicas baseadas em histórias-dilema. Nos estudos de Kohlberg, todavia, as histórias sobre situações do cotidiano infantil (utilizadas por Piaget) foram substituídas por dilemas hipotéticos de cunho existencial. E, enquanto Piaget se limitou a estudar o juízo moral de crianças pequenas até o início da adolescência, Kolhberg estendeu suas investigações até a idade adulta. Os resultados de suas pesquisas confirmam as teses centrais de Piaget: há um desenvolvimento do juízo moral, e esse desenvolvimento segue um caminho necessário em direção à autonomia a partir de processos de auto-regulação, desencadeados pelas interações com o meio social. As inovações metodológicas do psicólogo norte-americano, contudo, o levaram a algumas reformulações teóricas (Freitag, 2002).

Embora Kohlberg (1992) admita, com Piaget (1932/1994), que o desenvolvimento do juízo moral caminhe da heteronomia para a autonomia, o autor apresenta uma conceituação mais precisa e discriminada sobre o assunto, postulando uma sequência hierárquica e universal de seis estágios, distribuídos em três níveis: pré-convencional, convencional e pós-convencional. Os primeiros sinais de autonomia, encontrados por Piaget em crianças de aproximadamente 9 anos, só serão consolidados, segundo Kohlberg, na idade adulta e no denominado nível pósconvencional. Suas pesquisas mostram que tal nível é alcançado por poucos, o que não significa que todo e qualquer ser humano não tenha uma tendência a ascender aos estágios mais avançados do desenvolvimento. A autonomia moral, presente no final da sequência de estágios definida pelo autor, é uma conquista cara e rara, mas ainda assim é um potencial ao alcance de todos (La Taille, 2006b; 2007). Conheçamos, agora, os estágios propostos por Kohlberg.

O nível pré-convencional é dividido em dois estágios. No estágio 1, a moral é interpretada como obediência à autoridade e orientada para as consequências físicas da ação. No estágio 2, um ato moralmente correto é definido com base na satisfação das necessidades próprias e na manutenção das relações de trocas concretas. Aqui, a reciprocidade e a igualdade já aparecem, mas são ainda interpretadas de modo pragmático. 
No nível convencional, encontramos os estágios 3 e 4. No estágio 3, o moralmente certo corresponde a uma adequação às expectativas da família e do grupo em que se vive. Trata-se da moralidade do conformismo a imagens estereotipadas que ganham a aprovação de pessoas próximas. No estágio 4, há uma orientação em direção à autoridade, a regras fixas e à manutenção da estabilidade social. A moral aqui é definida como o cumprimento do dever social, em função da ordem e do bem estar da sociedade.

O nível pós-convencional, como os anteriores, é dividido em dois outros estágios. O estágio 5 é marcado por uma orientação para o contrato social democrático. Embora haja um reconhecimento da importância das regras para a preservação da ordem social, existe, nesse estágio, uma consciência clara do relativismo de valores e opiniões pessoais. Valores universais, como a vida e a liberdade, são defendidos independentemente da variedade dos juízos alheios, mas admite-se, aqui, a possibilidade de modificação de determinadas leis em função de considerações racionais de utilidade social. Tal modificação é buscada por meio de mecanismos legais e formais de acordo, contrato e imparcialidade objetiva. O sexto e último estágio transcende limites comunitários e sociais e enfatiza os princípios universais de justiça, que garantem a igualdade dos direitos humanos e o respeito à dignidade de cada indivíduo. Nesse estágio, as leis e os contratos sociais são válidos desde que se apoiem em tais princípios.

Se a evolução do juízo moral proposta por Kohlberg (1992), conforme acabamos de ver, segue em direção à legitimação de princípios universais de justiça, podemos afirmar que o autor nomeia essa virtude como o eixo do universo moral, e o desenvolvimento do juízo moral na sua teoria é, portanto, o desenvolvimento da noção de justiça. "Enquanto Piaget elegeu a justiça como objeto de pesquisa, mas sem afirmar que ela é a virtude maior da moral, Kohlberg fechou a questão: a justiça é a virtude moral por excelência, e não apenas uma entre outras" (La Taille, 2006b, p. 24).

Uma das críticas centrais à teoria de Kohlberg (1992) pode ser encontrada nos trabalhos da psicóloga norte-americana Carol Gilligan (1982), que questiona o princípio de justiça como única fonte da moralidade. A autora defende a existência de duas orientações morais: a ética do cuidado (care), mais presente nos juízos das mulheres; e a ética da justiça, que domina os juízos masculinos. Suas elaborações partem da suspeita de que autores consagrados, como Freud, Piaget e Kohlberg, menosprezam, de diferentes maneiras, as mulheres, julgando-as inferiores aos homens no que diz respeito à moral. Tal interpretação, segundo a psicóloga, está relacionada a uma tendência a eleger o comportamento masculino como padrão universal 
da moralidade, e a experiência feminina como uma espécie de desvio desse padrão. Nas palavras de Gilligan:

Adotando implicitamente a vida masculina como norma, tentaram vestir a mulher com um traje masculino (p. 16).... Assim, quando as mulheres não se ajustam aos padrões da expectativa psicológica, as conclusões têm sido, em geral, que alguma coisa está errada com as mulheres (p. 24).

A sensibilidade às necessidades dos outros e a presunção de responsabilidade por cuidar, de acordo com Gilligan (1982), “(...) infundem a psicologia do desenvolvimento das mulheres e são responsáveis pelo o que é tido em geral por problemático em sua natureza" (p. 27). Ao lado da ética da justiça, que vinha fundamentando a psicologia do desenvolvimento moral, a autora propõe, então, uma ética do cuidado, cujo silêncio das mulheres nas narrativas do desenvolvimento humano não nos permitia perceber.

Para Gilligan (1982), a origem da diferença entre as duas orientações morais está, fundamentalmente, na formação das identidades masculina e feminina durante os três primeiros anos de vida. Considerando que, nessa fase, a pessoa que cuida do bebê é tipicamente do sexo feminino (a mãe), o meio social é vivenciado de forma diferente por meninos e meninas. Enquanto os meninos rompem a identificação com a mãe e vivenciam um processo de separação dessa figura feminina, as meninas se identificam com ela e vivenciam sentimentos de proximidade com o outro materno, “(...) fundindo a experiência de apego com o processo de formação de identidade" (p. 18). Essas vivências femininas da infância estariam relacionadas, segundo a autora, à propensão da mulher a estabelecer vínculos, buscar relações de proximidade e estar atenta às necessidades, sentimentos e sofrimentos de outrem.

Gilligan (1982) não associa explicitamente a ética do cuidado à generosidade em seus textos, mas, com La Taille (2002b), acreditamos na validade de tal associação. Ao definir a inclinação moral feminina e exemplificá-la com trechos das entrevistas realizadas, a autora se aproxima, decisivamente, da generosidade, o que nos leva a considerá-la a "virtude típica da ética do cuidado" (La Taille, 2001a, p. 93).

Dediquemo-nos, agora, ao tema das virtudes e a sua relação com a moral para, em seguida, nos debruçarmos sobre a generosidade. 


\section{A MORAL E AS VIRTUDES}

Para maior clareza da exposição do tema das virtudes e da sua inserção no campo da moralidade, comecemos por fazer uma distinção entre moral e ética. Embora essas duas palavras sejam habitualmente empregadas como sinônimas, adotaremos, por convenção, uma possível diferenciação entre os dois termos, também assumida por autores como Ricoeur (1990), Tugendhat (1996), Comte-Sponville (1995/1997) e La Taille (2002a). Nas palavras de La Taille:

(...) chamamos de moral um conjunto de deveres, logo de obrigações ou imperativos que o sujeito coloca para si. A moral corresponde à pergunta: como devo agir? Chamemos de ética as buscas e preocupações acerca da felicidade, da realização de uma vida plena. A ética corresponde às perguntas: Que vida viver? ou Que vida vale a pena viver? Naturalmente, assim definida, a ética não remete a deveres, mas sim a aspirações (pp. 157 e 158).

É importante acrescentar que, embora tenham significados distintos, moral e ética são complementares e indissociáveis. De acordo com La Taille (2001b), ao respondermos que vida viver?, nos remetemos à pergunta como devo agir?. O autor ressalta, ainda, que a primeira pergunta implica uma outra: quem eu quero ser?, que coloca em pauta o tema da construção do Eu.

Com base nas proposições do autor francês Roger Perron (1991), La Taille (2001b) define o Eu como um conjunto de representações de si: “(...) são imagens, ideias, conceitos que cada pessoa tem de si” (p. 74). O termo é empregado no plural porque, de acordo com o autor, cada indivíduo não faz apenas uma representação de si mesmo, mas várias, que podem, inclusive, ser contraditórias entre si. La Taille (2002b) ressalta, ainda, que as representações de si são construídas como conjunto de valores, que podem ser positivos ou negativos:

Quando uma pessoa pensa em si, quando se representa para si mesma, todas as imagens que constrói estão intimamente associadas ao bem ou ao mal, ao desejável ou ao indesejável, ao certo ou ao errado, ao bonito ou ao feio, e assim por diante. Mesmo as formas aparentemente mais objetivas de se representar, como ser mulher ou homem, criança ou adulto, preto ou branco, casado ou solteiro, etc., estão prenhes de valor (p. 61).

Mas o que é valor do ponto de vista psicológico? É investimento de afetividade, conforme afirma Piaget (1954). Assim, quanto maior a carga afetiva vinculada a determinado valor, 
mais central é o seu posicionamento no conjunto das representações de si do indivíduo. Já aqueles valores que possuem força motivacional menor ocupam a periferia desse conjunto (La Taille, 2001b). Uma pessoa que, por exemplo, costuma roubar objetos alheios porque não quer trabalhar para ganhar seu próprio dinheiro, certamente, confere maior força motivacional a valores contraditórios com leis morais como não roubar. Em decorrência, tais valores são centrais nas representações de si que constituem o Eu dessa pessoa. Quando os valores morais ocupam uma posição central no sistema de representações de si de um indivíduo, podemos afirmar, segundo La Taille (2002b), que esse indivíduo possui uma personalidade ética.

Tognetta (2009; Tognetta \& La Taille, 2008), ao realizar um estudo com adolescentes de 12 a 15 anos de idade sobre a generosidade ligada às representações de si, encontrou uma correspondência entre os juízos morais relacionados a esse valor e as representações que os participantes têm de si mesmos. Segundo a autora, os adolescentes cujas representações de si são caracterizadas por conteúdos éticos apresentam juízos mais evoluídos no que diz respeito à generosidade e à sensibilidade aos sentimentos de outrem. Em uma pesquisa com adolescentes de 15 a 18 anos, Pinheiro (2009) verificou que, diante de um conflito moral envolvendo a generosidade, os jovens participantes mobilizaram esse valor integrado à amizade e aos sentimentos de culpa e vergonha.

La Taille (2001b) destaca três tipos de valores associados às representações de si: valores não morais, como a beleza física, a fama ou a glória; valores imorais, como, por exemplo, ser violento e valores coerentes com as regras morais, como a justiça. Há, ainda, segundo o autor, valores, como a generosidade, que, além de serem coerentes com as regras que normatizam as condutas humanas, conferem sentido às referidas regras, garantem a sua aplicação e ampliam sua significação humana. "Estes valores éticos são as virtudes" (p. 82), que também podem compor as representações de si do ser humano.

Mas o que chamamos de virtude neste trabalho? Em um primeiro momento, ComteSponville (1995/1997) define virtude como função de determinado objeto, como poder, mas poder específico. Assim, a virtude da faca é cortar, que não pode ser a mesma que a da enxada, por exemplo. Já no homem, continuando com o mesmo autor, virtude é uma maneira de ser e agir humanamente, é o esforço para agir bem, visto que o bem não é para ser contemplado, mas para ser feito. $\mathrm{O}$ autor afirma que as virtudes "são nossos valores morais, se quiserem, mas encarnados, tanto quanto quisermos, mas vividos, mas em ato" (p. 10). Nas palavras de Tugendhat (1996):

Embora no grego não haja nada mais natural do que no caso da "virtude" falar de um objeto de uso ou de um ginasta, isso não significa 
que, quando se fala das virtudes dos seres humanos enquanto seres humanos, isso seja compreendido funcionalmente; fala-se das propriedades do caráter dignas de aprovação (p. 245).

A palavra virtude pode, portanto, referir-se a qualidades que definem o caráter de uma pessoa. Esta é a definição que nos interessa no contexto deste trabalho. La Taille (2001b) diferencia qualidades de uma ação como cantar bem, ser bonito ou habilidoso de qualidades que remetem ao caráter de uma pessoa como ser generoso, corajoso ou justo. Enquanto nas primeiras admiramos fundamentalmente as ações, nas segundas, a pessoa que pratica as ações também é admirada: "Fala-se, com admiração, de sua personalidade, através de uma leitura valorativa desta" (La Taille, 2001b, p. 83).

Historicamente, a justiça vem sendo considerada a virtude moral por excelência, já que corresponde ao binômio direito/ dever. La Taille (2000) destaca a importância da justiça no campo da moralidade, mas defende o estudo de outras virtudes que não dizem respeito apenas a condutas determinadas por direitos alheios. Essa nova perspectiva, já iniciada por Gilligan (1982), é também proposta por outros autores como Flanagan (1996), Campbell e Christopher (1996) e Waterman (1995). A concepção de moral defendida aqui abre espaço para o ressurgimento da ética das virtudes, com nítida inspiração na moral aristotélica. Em sua obra intitulada Ética a nicômaco, Aristóteles (384-322 a.c./1992) define a moral como a busca do bem e da felicidade e, para o filósofo grego, "são os atos de virtude os únicos que decidem soberanamente a felicidade" (p. 87).

É importante destacar que o tema dos direitos e deveres e a questão da normatividade ainda são centrais nas pesquisas da área da moralidade. La Taille, Souza e Vizioli (2004), ao realizarem uma revisão da literatura (de 1930 a 2003) que versa sobre a relação entre ética e educação e temas relacionados, constataram que as virtudes e a busca da felicidade, praticamente, não aparecem. É possível que tal fato esteja relacionado à influência dos principais autores desse campo, como Kohlberg (1992) e Piaget (1932/1994), que se dedicaram, predominantemente, à noção de justiça. La Taille (2002b), no entanto, questiona a primazia dada a tal tema: "Vale dizer, longe de limitar-se a conflitos, deveres e regras prescritivas, a moral pode também tratar da "busca da felicidade"” (p. 29). Se a ética refere-se à busca da felicidade, faz sentido incluirmos nela as virtudes. Se para respondermos a questão da ética nos remetemos à questão da moral, podemos afirmar que as virtudes não só são coerentes com as leis morais, como “(...) correspondem a traços de caráter, sem os quais as leis podem permanecer letra morta" (La Taille, 2001b, p. 85). 
La Taille (2000) defende a importância de estudos psicológicos das virtudes com vários argumentos diferentes e, ao mesmo tempo, complementares. Entre estes, está a inserção do tema em uma possível definição do que seja moral ou ética, conforme acabamos de discutir. Um outro argumento apresentado pelo autor é o interesse universal do tema. Podemos encontrar referência às virtudes nas diversas literaturas, filosofias e religiões. Mesmo que receba um tratamento diferente, essas características humanas estão presentes em várias culturas, em vários momentos históricos, nas conversas entre os adultos e entre as crianças. E um último argumento utilizado por La Taille (2000) em favor de um estudo sobre o tema é a sua relevância psicológica na gênese da moralidade. La Taille et al. (1998), a partir da realização de pesquisas sobre as virtudes morais, constataram que noções de generosidade, coragem, fidelidade, gratidão e humildade já fazem parte do universo moral das crianças, que podem, inclusive, estabelecer diferenças sutis entre algumas.

Por fim, vale ressaltar que, nos últimos anos, notamos um aumento no número de produções científicas dedicadas a outras virtudes, além da justiça, no panorama das pesquisas sobre a moral. Destacamos, aqui, a pesquisa de La Taille (2001a) sobre a polidez; o trabalho de Dias (2002) sobre coragem e generosidade; os nossos estudos (Vale, 2006; Vale \& Alencar, 2008a; Vale \& Alencar, 2008b; Vale \& Alencar, 2009; Vale \& Alencar, no prelo) e também as pesquisas de Tognetta (2003, 2009; Tognetta \& Assis, 2006; Tognetta \& La Taille, 2008), La Taille (2006a) e Pinheiro (2009) sobre a generosidade; as produções científicas sobre a gratidão (Pieta, 2009; Freitas, Silveira \& Pieta, 2009a, 2009b; Mileski, 2010; Castro, Rava, Hoefelmann, Pieta \& Freitas, 2011); sem falar de outros trabalhos sobre as virtudes em geral (La Taille, 2000, 2009b; Tognetta, 2007).

Defendida a importância social e científica de estudos psicológicos das virtudes morais, nos dedicaremos, agora, à virtude que elegemos estudar nesta investigação: a generosidade. 


\section{A GENEROSIDADE}

Para discorrermos sobre a generosidade, comecemos apontando algumas diferenças entre essa virtude e a justiça, que, como vimos, foi objeto de pesquisa de autores consagrados no campo da moralidade, como Kohlberg (1992) e Piaget (1932/1994). Nas palavras do filósofo francês Comte-Sponville (1995/1997):

(...) a generosidade é mais subjetiva, mais singular, mais afetiva, mais espontânea, ao passo que a justiça, mesmo quando aplicada, guarda em si algo mais objetivo, mais universal, mais intelectual ou mais refletido. A generosidade parece dever mais ao temperamento; a justiça, ao espírito ou à razão (p. 97).

De acordo com Comte-Sponville (1995/1997), ser generoso é oferecer ao outro algo que não the pertence, mas que lhe falta. A generosidade, segundo La Taille (2006a), não está relacionada a um direito alheio, pois, quando somos generosos, damos ao outro o que corresponde a uma necessidade singular, e não o que lhe compete de direito ${ }^{1}$. E, se o que fazemos pelo outro quando somos generosos não configura um direito seu, não temos o dever de fazê-lo. O exercício dessa virtude não corresponde a uma exigência social e depende de uma decisão livre do sujeito. Conforme afirma La Taille (2006a), “(...) ninguém pode, com legitimidade, exigir ser tratado de forma generosa, somente pode desejá-lo" (p. 10). Nesse contexto, as leis, as sanções, as imposições de figuras de autoridade e as obrigações formais são irrelevantes. A justiça, por sua vez, pode sim ser objeto legítimo de reivindicação pessoal, já que é a única virtude que corresponde ao binômio direito/ dever: “(...) se é reconhecido a alguém um direito, os outros têm o dever de respeitá-lo" (La Taille, 2000, p. 114).

A generosidade é também definida por Comte-Sponville (1995/1997) como a virtude do dom. Godbout (1992) qualifica dom como "toda prestação de bens ou de serviços efetuada, sem garantia de retribuição (...)" (p. 30). Esse desprendimento presente no ato generoso não ocorre na justiça, que tem a reciprocidade como uma de suas características: “(...) faz sentido alguém ao mesmo tempo sentir-se no dever de ser justo e no direito de exigir que o tratem justamente" (La Taille, 2000, p. 116). Na justiça, o auto-interesse, ao lado do interesse pelo outro, está sempre presente: “A lei justa é boa para todos, inclusive para a pessoa que exerce a justiça” (La Taille, 2006b, p. 62). Na generosidade, todavia, apenas o interesse pelo outro está

\footnotetext{
${ }^{1}$ É importante destacar, aqui, a associação da generosidade com a ética do cuidado proposta por Gilligan (1982), que também pressupõe uma atenção às necessidades singulares alheias.
} 
em jogo. Nas palavras de La Taille (2006b): "O ato de generosidade favorece quem é por ele contemplado, não quem age de forma generosa. É por ser a generosidade a inteira dedicação a outrem que digo que ela traduz plenamente o altruísmo" (p. 62).

Apresentadas algumas diferenças entre a generosidade e a justiça, comparemos, agora, a generosidade com a solidariedade. Embora essas duas palavras sejam, muitas vezes, utilizadas como sinônimas, julgamos necessário apontar as diferenças. Basta consultarmos o dicionário (Houaiss \& Villar, 2001) para notar que, enquanto a generosidade se refere à liberalidade, bondade e magnanimidade; a solidariedade diz respeito à interdependência, cooperação, responsabilidade mútua, mutualidade de interesses e deveres ou vínculo recíproco. Nesse caso, ajudamos o outro porque, dessa forma, nos ajudamos. Nas palavras de Comte-Sponville (1995/1997):

\begin{abstract}
A solidariedade é antes de mais nada o fato de uma coesão, de uma interdependência, de uma comunidade de interesses ou de destino. Ser solidário, nesse sentido, é pertencer a um mesmo conjunto e partilhar, consequentemente - quer se queira, quer não, quer se saiba, quer não uma mesma história (p. 98).
\end{abstract}

A presença do auto-interesse é marcante na solidariedade. Colegas de um grupo de trabalho acadêmico, por exemplo, podem ser solidários entre si por interesse próprio. Uma criança pode encobrir uma transgressão do irmão para evitar que este fique de castigo e, assim, ter companhia para brincar. Nessas situações, não há o desprendimento, como já dissemos, pressuposto moralmente pela generosidade. Por isso, Comte-Sponville (1995/1997) afirma que “(...) a solidariedade é demasiado interessada ou demasiado ilusória para ser uma virtude. Nada mais é que egoísmo bem entendido ou generosidade mal entendida” (p. 99). O autor ressalta que esse valor parte do princípio do agir para receber ou mesmo para se livrar de uma ação constituída na sociedade como um dever, no sentido de preocupar-se com o bem coletivo e com as agruras que os grandes desastres naturais provocam sobre determinados indivíduos.

Comte-Sponville (1995/1997) acrescenta que a solidariedade pode motivar, suscitar e reforçar a generosidade. "Mas ela só é verdadeiramente generosa desde que vá além do interesse, ainda que bem compreendido, ainda que partilhado - logo, contanto que vá além da solidariedade!" (p. 101). Mas até que ponto podemos afirmar que, no ato generoso, não há interesse próprio algum? Ao sermos generosos, não recebemos algum tipo retribuição?

La Taille (2000) afirma que uma pessoa não se beneficia materialmente ao ser generosa, mas pode experimentar prazer ou felicidade com seu ato. Godbout (1992), ao discorrer sobre 
o dom, afirma que a retribuição existe, mesmo quando esta não é desejada. Ampliando a definição da palavra e, dessa forma, ultrapassando a circulação material dos objetos ou dos serviços, o autor cita o reconhecimento que o ato suscita como uma importante retribuição para os doadores. Ora, aqui, nossa discussão sobre a generosidade nos remete à gratidão, a mais agradável das virtudes e o mais virtuoso dos prazeres, segundo Comte-Sponville $(1995 / 1997)$.

A gratidão é o reconhecimento espiritual de uma dívida (La Taille, 2000), é saber ver na generosidade do outro a causa de sua alegria e ser capaz de retribuir parte dessa alegria recebida e sentida (Comte-Sponville, 1995/1997). Mas como se dá essa retribuição? Ou, parafraseando Comte-Sponville, “o que a gratidão dá?” (p. 146). A recompensa material (um presente, por exemplo) pode ser uma autêntica expressão de gratidão, o que não nos leva a supor, todavia, que em todo e qualquer retorno de objeto ao outro haja, de fato, um reconhecimento de dívida àquele que lhe foi generoso. Para Comte-Sponville, “(...) a gratidão é levada a agir (...) em favor de quem a suscita, não decerto para trocar um obséquio por outro (não seria mais gratidão, e sim troca) (...)” (p. 148). Na concepção do autor, essa virtude pode, inclusive, prescindir de qualquer tipo de recompensa material: "a gratidão nada tem a dar, além do prazer de ter recebido” (p. 146). Segundo o filósofo, a gratidão dá a si mesma, “(...) é um segundo prazer, que prolonga um primeiro, como um eco de alegria à alegria sentida, como uma felicidade a mais para um mais de felicidade" (p. 145).

Podemos afirmar, portanto, que ao sermos generosos podemos receber e, na maioria das vezes, recebemos algum tipo de retorno, que, como vimos, não se aplica necessariamente a algo material. O que há de característico na generosidade é que a retribuição é inesperada, não é exigida, não é garantida quando se dá. "Dizer que há um direito em receber a gratidão de outrem chegaria a aniquilar o valor dessa virtude: ou ela é espontânea, ou ela não é” (La Taille, 2000, p. 115). E também não pode haver interesse próprio em ser generoso e, se houver, não se trata de generosidade (La Taille, 2000). Como diz Godbout (1992), esse gesto é inteiramente satisfatório em si mesmo. "Por fim, e estranhamente, a retribuição está frequentemente no próprio dom, na inspiração do artista, na transformação pessoal que experimentam os doadores (...)" (Godbout, 1992, p. 136).

$\mathrm{Na}$ época do Natal, algumas crianças acreditam receber presentes do famoso personagem Papai Noel, aquele velhinho generoso que produz brinquedos diversos e os distribui na noite natalina. Nesse caso, nem o reconhecimento que o ato suscita é esperado pelos verdadeiros autores do ato, já que esse retorno é dirigido a um outro irreal. Para os pais, o que parece 
contar é o prazer sentido pelos filhos. Mas podemos considerar que há generosidade na família?

Comte-Sponville (1995/1997) afirma que o amor basta para explicar o que fazemos por nossos familiares e amigos próximos, pois a felicidade destes é a nossa também. A alegria dos pais é perceber a alegria sentida por seus filhos ao receberem os presentes de Natal, por exemplo. $\mathrm{O}$ autor argumenta, no entanto, que, muitas vezes, o desejo dos pais opõe-se ao de seus filhos. $\mathrm{O}$ entusiasmo da criança para brincar pode coincidir com o cansaço de um dia de trabalho do pai, por exemplo. Para Comte-Sponville, são nessas oportunidades que se podem dar provas de generosidade. "É simplificar excessivamente não querer ver nenhuma generosidade possível ou necessária em relação a eles” (p. 102). O mesmo autor destaca, todavia, que "dar, quando se ama, está ao alcance de qualquer um" (p. 107). E quando não se ama?

Segundo Comte-Sponville (1995/1997), “(...) a generosidade nos convida, na falta de amor, a dar exatamente aos que não amamos, por necessitarem mais ou por estarmos mais bem situados para ajudá-los" (p. 110). Para o autor, o amor não está em nosso poder, mas a generosidade depende de nosso comando. "Portanto, não se trata de amar, mas de agir como se amássemos" (p. 108). Se dependêssemos apenas do amor para dar a outrem, o que seria dos estranhos ou desconhecidos que carecessem de nossa ajuda? Godbout (1992) afirma que a possibilidade de dar a estranhos, longe de ser um resíduo das sociedades tradicionais, é um traço moderno. Ressalta que esse dom moderno pode ser encontrado entre pessoas de todos os meios sociais, não apenas sob a forma monetária, mas também sob a forma de tempo, como a escuta, as visitas e o acompanhamento de idosos.

É útil saber, ainda, que a generosidade, não raras vezes, exige sacrifício, esforço contra tendências adversas e reflexão, por isso essa virtude aponta para a excelência (La Taille, 2001a). Para melhor compreendermos essa questão, analisemos o conteúdo de uma históriadilema que utilizamos em uma de nossas pesquisas sobre a generosidade (Vale, 2006; Vale \& Alencar, 2008a) ${ }^{2}$ : depois de uma semana inteira de chuva, uma criança que adora nadar é convidada por seus pais para ir à praia em um domingo de sol. Nesse momento, seu vizinho, que estava com a perna engessada, a convida para brincar. Podemos afirmar que há, nessa história, um conflito entre a possibilidade de a criança manifestar a generosidade para com seu vizinho (fazendo-lhe companhia para brincar) e a oportunidade da mesma satisfazer um interesse próprio (nadar na praia em um domingo de sol).

\footnotetext{
2 Mais adiante, comentaremos os resultados e as contribuições dessa pesquisa para nosso trabalho.
} 
O conflito proposto nos remete ao conceito de vontade (força de vontade) apresentado por Piaget em um curso que ministrou na Universidade de Sorbonne, em 1954. O autor comparou a vontade no plano afetivo às operações mentais no plano cognitivo: assim como as operações regulam e direcionam o pensamento livrando-o das ilusões perceptivas, a vontade liberta o ser humano dos desejos e interesses imediatos. Dessa forma, referindo-se a um conflito entre duas tendências, entre um prazer tentador e um dever, Piaget (1964/2003) afirma:

(...) sempre há uma tendência inferior mais forte por si mesma (o prazer desejado, neste exemplo) e uma tendência superior, mas no momento mais frágil (o dever). $\mathrm{O}$ ato da vontade consiste, portanto, não em seguir a tendência inferior e forte (ao contrário, fala-se, neste caso, de um fracasso da vontade ou de uma "vontade fraca"), mas em reforçar a tendência superior e frágil, fazendo-a triunfar (p. 56).

Voltemos à história-dilema que propomos: parece-nos válido associar a tendência inferior e mais forte, mencionada por Piaget (1964/2003), ao interesse imediato de ir à praia. Mas poderíamos associar o dever (a tendência superior e mais frágil) à manifestação de generosidade para com o outro? Ora, vimos que a generosidade, diferente da justiça, não pode ser objeto legítimo de reivindicação pessoal. Na situação apresentada, a criança supostamente em conflito não tem o dever de brincar com seu vizinho que se encontra com a perna engessada, abdicando de ir à praia com seus pais. Da mesma forma, ter companhia para brincar naquele domingo de sol não configura um direito de seu vizinho. Se a generosidade não corresponde ao binômio direito/ dever, como poderíamos, então, associá-la ao dever, mencionado por Piaget ao abordar o conceito de vontade?

La Taille (2002b) afirma que um direito determina um dever, mas, pelo menos psicologicamente, a recíproca não é verdadeira. Algumas pessoas, segundo o autor, podem ser movidas por um sentimento de dever quando colocam para si a obrigação de agir com generosidade “(...) sem pensar que a pessoa favorecida tenha direito de reivindicar o 'dom', e também sem pensar que qualquer outra pessoa na mesma situação deveria necessariamente agir da mesma forma" (p. 26). Nesse caso, o sentimento de obrigatoriedade não procede do reconhecimento de um direito da pessoa contemplada, como ocorre em um ato de justiça. Mas se esse sentimento de dever não deriva de um direito alheio, como podemos defini-lo então?

La Taille (2006b) define o dever como um tipo particular de querer. Segundo o autor, "querer" e "dever" não devem ser pensados como opostos, mas como "quereres" diferentes:

(...) somente age moralmente quem se sente intimamente obrigado a tal, e não quem é coagido por algum poder exterior. Logo, o sujeito moral é, por definição, livre, porque é ele mesmo quem decide agir por dever. 
Dito de outra forma, somente é moral quem assim o quer (La Taille, 2006b, p. 54).

Esclareçamos fazendo uso da história-dilema em questão. Se considerarmos que a criança em conflito, depois de refletir, decide deixar de fazer um programa desejável (ir à praia) para ser generosa com seu vizinho que se encontrava com a perna engessada, parece-nos válido afirmar que ela mesma se obriga a cumprir um dever. E não podemos atribuir a razão de seu gesto à outra coisa senão ao seu querer e, portanto, à sua vontade, no sentido piagetiano do termo. Mas ela também não queria ir à praia? Sim. Trata-se, nesse caso, de "quereres" conflitantes, e, se a criança opta por deixar de ir à praia para fazer companhia ao seu vizinho, é porque o querer manifestar a generosidade foi mais forte para essa criança do que o querer satisfazer seu próprio interesse. Em outros termos, fazendo uso das palavras de Piaget (1964/2003), a vontade fez triunfar a tendência superior e frágil, a saber: a generosidade.

A generosidade pode, portanto, corresponder a um sentimento de obrigatoriedade, que não deriva de um direito alheio nem coincide com a exigibilidade exterior. Ora, se a generosidade depende de uma decisão livre do sujeito (que pode ou não se sentir pessoalmente obrigado a agir de forma generosa), e o sujeito moral, como vimos acima, é livre porque é ele mesmo quem decide agir por dever, parece-nos pertinente admitir que Gilligan (1982) tinha razão quando propôs, ao lado da ética da justiça, a ética do cuidado, que nos remete à generosidade. Nas palavras de La Taille (2002b): “(...) a generosidade redimensiona a questão do dever, da obrigatoriedade, fato que, ao lado do abandono da definição de moral como exclusivamente relacionada a direitos, também modifica sensivelmente o panorama das pesquisas sobre o que se chama moralidade humana" (p. 26).

Se Gilligan (1982) tinha razão quando propôs uma modificação, e consequente ampliação, na definição do objeto da moralidade, a autora estava também correta ao afirmar a existência de duas orientações morais universais ao invés de apenas uma? Há de fato um desenvolvimento moral feminino (ética do cuidado) que difere do desenvolvimento masculino (ética da justiça)? Ou há um único desenvolvimento moral do qual a generosidade, e não somente a justiça, faz parte? E, se podemos situar a generosidade no campo da moral, pode essa virtude desempenhar um papel na gênese da moralidade? Como responderíamos a essas perguntas se tomássemos como base as teorias de Piaget (1932/1994) e Kohlberg (1992) sobre o desenvolvimento do juízo moral? Há espaço para a generosidade nas perspectivas teóricas desses autores, que privilegiaram a justiça como objeto de pesquisa? Debrucemo-nos sobre 
essas questões. Para tanto, voltemos às elaborações de Piaget e Kohlberg e recorramos às pesquisas sobre a generosidade que, certamente, nos oferecem algumas respostas.

\subsection{A generosidade e o desenvolvimento moral}

Para discutirmos as questões propostas na seção anterior, invertamos a ordem cronológica das elaborações teóricas e iniciemos com Kohlberg (1992).

Vimos anteriormente que Kohlberg (1992) elegeu a justiça como o cerne da moralidade e a única organizadora do desenvolvimento moral. As críticas levantadas por Gilligan (1982), contudo, levaram o autor a rever aspectos da sua teoria e a reconhecer que o campo da moral não se restringe à justiça, diferentemente do que vinha enfatizando em seus estudos. Em um artigo intitulado $O$ retorno do estágio 6: seu princípio e ponto de vista moral, Kohlberg (1990/2002), em co-autoria com Boyd e Levine, ressaltou que o princípio de respeito pelas pessoas inclui atitudes gerais de justiça e, também, de benevolência. Para ilustrarem os pontos destacados nesse artigo, os autores fizeram uso de dados obtidos em entrevistas sobre o juízo moral, realizadas com dois participantes que não faziam parte da amostra original de Kohlberg. De acordo com Kohlberg et al. (1990/2002), um dos entrevistados, em resposta a um dilema moral proposto, “(...) identifica a consciência que os autores têm de que as pessoas sentem necessidade de ajudar as outras, disposição que chamamos de benevolência (...)" (p. 104). Da mesma forma, para o outro entrevistado, segundo os autores, “(...) a ideia de respeito não inclui apenas evitar violar os direitos de outra pessoa em um sentido negativo, mas inclui também um sentido de responsabilidade positiva pelas necessidades e bem estar de outra pessoa" (p. 105). A benevolência ilustrada nesses trechos não nos remete à ética do cuidado proposta por Gilligan e, portanto, à generosidade? Parece-nos lícito responder que sim. Podemos, então, a partir da teoria de Kohlberg, defender a tese de Gilligan sobre a existência de duas orientações morais universais? Ora, Kohlberg parece concordar com Gilligan no que diz respeito à ampliação do campo da moral, mas não admite a existência de duas orientações morais universais. $\mathrm{O}$ autor recusa a tese de que homens e mulheres percorreriam trajetórias distintas de desenvolvimento moral e, embora destaque a benevolência na análise de algumas entrevistas, mantém a ênfase na noção de justiça por considerá-la uma virtude que possibilita a universalização de princípios morais. Para Kohlberg, o princípio de justiça sempre será um pressuposto para o altruísmo, a responsabilidade e o cuidado para com o outro. 
Concordamos com La Taille (2002b) quando afirma que a escolha kohlberguiana da justiça como eixo do desenvolvimento moral não é decorrência necessária da obra de Piaget (1932/1994). É verdade que o epistemólogo suíço dedicou um capítulo inteiro de seu livro sobre o tema ao estudo dessa virtude, mas também é verdade que o autor não restringiu o rumo seguido pelo desenvolvimento moral à legitimação de princípios universais de justiça como o fez Kohlberg (1992). Vimos anteriormente que, para Piaget, esse desenvolvimento segue um caminho necessário em direção à autonomia, quando a criança começa a experimentar interiormente a necessidade de tratar o outro como gostaria de ser tratada. Embora Piaget não restrinja a autonomia ao ideal de justiça, é inegável a inclusão dessa virtude na sua concepção teórica de moral autônoma: respeitamos o direito alheio assim como gostaríamos que nossos direitos fossem respeitados. O próprio autor nos mostrou a importância da justiça na forma mais evoluída da moral, dedicando o seu capítulo sobre a autonomia às suas pesquisas sobre essa virtude. Mas não poderíamos incluir também a generosidade nessa concepção teórica?

Voltemos à história-dilema que apresentamos na seção anterior. Supomos que a criança em conflito decide abdicar de um dia na praia para fazer companhia para seu vizinho, que se encontrava com a perna engessada. Poderíamos admitir a ideia de que essa criança se obriga a ser generosa para com o outro porque, se estivesse na mesma situação, também gostaria de ser contemplada com a mesma generosidade? Nossa resposta é afirmativa. Embora possa haver uma série de razões para a manifestação de uma ação generosa (o que, muitas vezes, implica a descaracterização da mesma), podemos sim tratar generosamente uma pessoa que carece de ajuda porque, nos encontrando na mesma situação, é dessa forma que gostaríamos de ser tratados. Ora, tal afirmativa nos leva à plausível inclusão da generosidade na concepção piagetiana de moral autônoma, já levantada por La Taille (2002b) ao defender o estudo psicológico sobre outras virtudes além da justiça:

Longe de restringir a autonomia, portanto a forma mais evoluída da moral, a uma esfera só, Piaget parece admitir que suas traduções são múltiplas, tanto em termos de consciência, como em termos de condutas. Estamos aqui, cremos, mais perto de um estudo de várias virtudes do que de pesquisas sobre uma só como o fez Kohlberg (p. 19).

Nossos argumentos sobre uma possível inclusão da generosidade na concepção de Piaget (1932/1994) sobre a moral não terminam por aqui. Ocupemo-nos, agora, de algumas citações contidas em sua obra sobre o juízo moral na criança que, se lidas cuidadosamente, parecem revelar intuições do autor relacionadas à generosidade. Eis as primeiras palavras de Piaget que 
merecem nossa atenção: "É quando a criança está habituada a agir de acordo com os pais e quando procura mais agradar-lhes que obedecer-lhes, que consegue julgar em função das intenções" (p. 112). De imediato, podemos destacar que, nessa citação, Piaget nos remete à passagem da heteronomia (que tem como uma de suas características a obediência cega a figuras de autoridade como os pais) para a autonomia, cuja responsabilidade subjetiva (ou seja, a capacidade de julgar em função das intenções) é um traço marcante. Mas, com La Taille (2006a), ressaltamos que essa citação nos traz mais informações. O emprego do verbo agradar nos sugere uma tendência a considerar o outro na sua singularidade e, dessa forma:

(...) fica clara a tese piagetiana segundo a qual um dos fatores que leva uma criança pequena a desenvolver-se moralmente é sua capacidade e motivação em corresponder às expectativas singulares das pessoas de seu entorno. Eis exatamente o que se faz nos atos generosos (La Taille, 2006a, p. 14).

Se Piaget (1932/1994) nos indica, na citação acima, que a gênese da responsabilidade subjetiva, característica da autonomia, emana do desejo da criança de agradar os outros, e se, com La Taille (2006a), podemos relacionar o emprego do verbo agradar à generosidade, podemos ressaltar a importância dessa virtude na gênese da moralidade na criança. Vejamos mais um trecho da obra de Piaget para verificarmos se estamos corretos de fato:

Certamente, as relações da criança com os pais não são apenas relações de coação. Há uma afeição mútua espontânea que impele a criança, desde o princípio, a atos de generosidade e mesmo de sacrifício, a demonstrações comoventes que não estão absolutamente prescritas. Aí está, sem dúvida nenhuma, o ponto de partida daquela moral do bem que veremos desenvolver-se à margem daquela do dever e que triunfará completamente em alguns indivíduos (pp. 154 e 155).

Nessa citação, Piaget (1932/1994) não só fala explicitamente da generosidade como menciona a espontaneidade, característica dessa virtude, e o sacrifício, não raras vezes exigido nos atos generosos, conforme já vimos. $\mathrm{O}$ autor não só inclui a generosidade no universo moral infantil, não o restringindo às relações de coação, como relaciona essa virtude ao ponto de partida para o desenvolvimento da moral autônoma (moral do bem), destacando, portanto, a sua relevância psicológica na construção da moralidade. Vejamos, agora, alguns resultados de pesquisas que nos levam a concordar com Piaget.

Em um dos estudos que realizamos sobre a generosidade (Vale 2006; Vale \& Alencar, 2008a), apresentamos a história-dilema exposta na seção anterior a alunos de 7, 10 e 13 anos de uma escola pública de Vitória - ES. Perguntamos aos participantes o que a personagem supostamente em conflito deveria fazer: ir à praia com os pais em um domingo de sol ou fazer 
companhia para seu vizinho, que estava com a perna engessada. Verificamos que, em todas as faixas de idade pesquisadas, a maioria dos participantes opta pela ação generosa em detrimento da satisfação do próprio interesse. A alta porcentagem de entrevistados de 7 anos (90\%) que decidem pela manifestação de generosidade demonstra que essa virtude é valorizada pela criança pequena e, portanto, faz parte do universo moral infantil.

Em um outro estudo sobre a generosidade, apresentamos aos participantes já citados acima uma outra história que trazia uma situação escolar em que a falta de generosidade de um aluno é observada por sua professora (Vale 2006; Vale \& Alencar, 2008b). Coube a cada entrevistado responder ao que a professora deveria fazer com esse aluno e se a mesma deveria castigá-lo. Verificamos que a maioria dos participantes sugere a conversa, e não a punição, como consequência da ausência de generosidade. Essa resposta predomina nas três faixas etárias, embora a porcentagem correspondente aumente em função da idade. Os entrevistados de 7 anos, em sua maioria, não só compreendem e valorizam a generosidade como são capazes de diferenciar a falta dessa virtude de transgressões claramente morais e, portanto, merecedoras de punição. Os participantes de 10 e 13 anos mencionam, inclusive, que essas transgressões se distinguem da não manifestação de generosidade pelo seu caráter de obrigatoriedade.

Resultado semelhante foi encontrado por La Taille et al. (1998), quando solicitaram a participantes de 6 a 12 anos que comparassem uma personagem que não age de forma generosa com uma outra que comete um ato de injustiça. Segundo os autores, a maioria dos entrevistados, inclusive os mais novos, dispensa a punição para a personagem não generosa e alega que a sanção deveria cair apenas sobre a personagem não justa. Os autores também verificaram que a maioria das crianças de 6 anos já afirma que uma personagem que se priva de uma fruta predileta para dá-la ao irmão (generosidade) é moralmente mais admirável do que outra que segue uma regra justa como dividir um pacote de biscoitos destinado a ela e ao irmão. Os resultados dessa pesquisa contribuíram para que La Taille (2000) destacasse a relevância psicológica da generosidade na gênese da moralidade: "Vale dizer que podemos levantar a hipótese de que, no caminho para a construção do ideal de justiça, a generosidade (e outras virtudes altruístas, que levam em conta o outro na sua especificidade) desempenha um papel" (p. 118).

Vimos anteriormente que Piaget (1932/1994) estabeleceu três grandes períodos no desenvolvimento da justiça na criança. No terceiro e último período, segundo o autor, “(...) o igualitarismo simples cede o passo diante de uma noção mais refinada de justiça, que podemos chamar a 'equidade', a qual consiste em nunca definir a igualdade sem considerar a 
situação particular de cada um" (p. 216). Ora, se a forma mais refinada de justiça pressupõe considerar o outro na sua particularidade, como fazemos nos atos generosos, a hipótese de La Taille (2000) de que a generosidade abre o caminho para a construção do ideal de justiça parece-nos válida. Os resultados de uma outra pesquisa parecem ir ao encontro dessa hipótese.

La Taille (2006b) e sua equipe de pesquisa perguntaram a participantes de 6 e 9 anos o que deveria fazer uma criança que recebeu um pacote de balas do pai enquanto seu irmão nada recebeu. Três opções foram apresentadas aos entrevistados: a criança deveria fazer nada; deveria dar algumas balas ao irmão ou deveria dividir as balas com ele. A primeira opção revela, segundo o autor, uma falta de compromisso para com o irmão; a segunda evidencia uma atitude generosa, e a terceira, um ato de justiça. De acordo com La Taille, a maior parte dos participantes de 6 anos optam pela segunda solução, enquanto os entrevistados de 9 anos decidem pela terceira. Nas palavras do autor:

Esses dados mostram, por um lado, a preocupação das crianças menores para com outrem e, por outro, a prevalência, nelas, de ações inspiradas pela generosidade, mesmo quando se lhes apresenta uma situação de injustiça. Portanto, não parece ser clara e forte a ideia de que outrem, no caso o irmão, possui direitos que elas mesmas poderiam garantir (dividindo o pacote de balas). Para as crianças maiores, tal clareza existe, assim como o sugerem nossos dados (p. 125).

À hipótese que apresentamos acima, La Taille (2006a) acrescenta uma outra: "a generosidade não somente é virtude presente no início da gênese da moralidade, como é melhor assimilada e, portanto, integrada à consciência moral, do que a justiça nesta mesma fase do desenvolvimento" (p. 16). Mas vimos anteriormente que, no início da gênese da moralidade, o respeito da criança às regras morais decorre da fusão entre os sentimentos de medo e amor pelas figuras que representam a autoridade, notadamente os pais. Como a criança pequena poderia, então, melhor assimilar a generosidade, se essa virtude, diferente da justiça, é tão pouco dependente das imposições do adulto?

Piaget (1932/1994) afirma, como já mostramos, que a vida moral infantil vai além das relações de coação e da obediência cega à autoridade. Com base nessa afirmativa, La Taille (2006b) menciona, ao lado do amor e do medo, outros sentimentos que comparecem no despertar do senso moral, entendido pelo autor como a fase do desenvolvimento em que se instalam as bases afetivas do dever, um tipo particular de querer, conforme vimos na seção anterior. Eis os outros sentimentos eleitos por La Taille a partir de suas leituras e pesquisas: confiança, simpatia, indignação e culpa. Dos sentimentos citados, destacamos a simpatia, que, de acordo com o autor, tem íntima relação com a generosidade. 
A simpatia, segundo Piaget (1954), é um sentimento baseado em juízos de valor mútuos entre os indivíduos e ocorre mediante um contato perceptual. Em um pequeno trecho de sua obra sobre o juízo moral na criança (1932/1994), o autor chega a mencionar a presença da simpatia na mais tenra infância e a relevância desse sentimento e, consequentemente da generosidade, no desenvolvimento da responsabilidade subjetiva, característica da autonomia. Referindo-se à responsabilidade objetiva, traço marcante da heteronomia, Piaget (1932/1994) ressalta: "É somente por um esforço contínuo de simpatia e de generosidade que resistimos a tal tendência e procuramos compreender as reações de outrem em função da intenção. Que a criança seja capaz, muito cedo, desta 'intropatia', é evidente” (p. 145). Nas últimas páginas do mesmo livro, o autor reafirma a precocidade da simpatia e a sua importância na gênese da moralidade: “(...) o comportamento da criança quanto às pessoas demonstra, desde o princípio, tendências à simpatia e reações afetivas, nas quais é fácil encontrar o estofo de todas as condutas morais ulteriores" (p. 296).

Para o filósofo Adam Smith (1759/1999), a simpatia nos faz experimentar as situações de outras pessoas e dividir com estas os sentimentos que tais circunstâncias tendem a despertar. Tal acepção aproxima-se de uma das definições de simpatia apresentadas no dicionário: faculdade de compenetrar-se das ideias ou sentimentos de outrem (Houaiss \& Villar, 2001). A mesma proximidade pode ser encontrada no conceito de empatia apresentado nos trabalhos de Hoffman (1978), que a considera uma resposta afetiva à situação na qual o outro se encontra. Para Cecconello e Koller (2000), a empatia consiste em compartilhar emoções percebidas do outro, seja positivas seja negativas. Já a simpatia, segundo as autoras, geralmente se refere a sentimentos de tristeza ou lamento e consiste em uma intensa preocupação com o sofrimento alheio.

No que diz respeito à preferência por um conceito ou outro e às nuanças que separam as definições, La Taille (2006a) ressalta que tanto a simpatia quanto a empatia se referem a um 'operador emocional', passível de motivar uma pessoa a preocupar-se com outra. Para fins didáticos, em nosso trabalho, utilizaremos apenas a palavra simpatia, entendida aqui como a capacidade humana de comover-se com os estados afetivos alheios.

Definido o sentimento de simpatia no contexto deste estudo, estabeleçamos, fazendo uso das palavras de La Taille (2006a), a sua relação com a virtude generosidade:

No que tange à relação entre generosidade e simpatia (ou empatia), ela é clara, uma vez que o exercício da referida virtude pressupõe perceberse a necessidade singular de uma determinada pessoa (ou grupo de pessoas), e contemplá-la por intermédio de um 'dom de si'. Uma pessoa por ventura incapaz de simpatia talvez nem percebesse a 
necessidade alheia, certamente não se comoveria com ela, e, por conseguinte, não agiria de forma generosa (p. 12).

Os resultados de nossas investigações sobre a generosidade confirmam tal relação (Vale, 2006; Vale \& Alencar, 2008a; Vale \& Alencar, 2008b; Vale \& Alencar, 2009; Vale \& Alencar, no prelo). Em todas as nossas pesquisas sobre os juízos de crianças e adolescentes relacionados a essa virtude, as condições de quem precisava de ajuda são mencionadas por participantes de todas as faixas etárias para justificar a decisão pela generosidade. "O João (o vizinho da história contada anteriormente) não tinha ninguém para brincar, estava triste e não podia ir à praia porque estava com a perna engessada”, explicou, por exemplo, um de nossos entrevistados. Ao ressaltarem essas condições, nossos participantes não demonstram uma capacidade de comoção com o estado em que o outro se encontrava? Não há aí um tipo de sensibilidade para com o sofrimento do outro? Parece-nos lícito responder que sim. Podemos, então, destacar o sentimento de simpatia nessas justificativas? Nossa resposta permanece afirmativa. Considerando que esse tipo de justificativa prevalece sobre os demais na maioria das situações apresentadas aos entrevistados, nossos dados parecem apontar, portanto, para a íntima relação desse sentimento com a virtude generosidade.

Se a generosidade é inspirada pela simpatia, o exercício dessa virtude é produto da sensibilidade da criança mais do que de sua disposição para obedecer à autoridade adulta (La Taille, 2006b). É justamente esse aspecto que leva La Taille (2006a) a apresentar a hipótese de que a generosidade é mais bem assimilada do que a justiça por parte das crianças pequenas. Sabemos que, na fase da heteronomia, as regras de justiça são impostas pelo adulto e, de acordo com Piaget (1932/1994), permanecem exteriores à consciência da criança. Os atos de generosidade inspirados pela simpatia, todavia, são espontâneos e, para La Taille (2006b), favorecem uma compreensão mais autônoma do valor dessa virtude. Segundo o autor, “(...) enquanto a regra imposta dá mais ênfase à obediência do que à pessoa-alvo da ação proibida, a simpatia faz o contrário, dando mais visibilidade a outrem e, por conseguinte, a uma das razões essenciais de ser da moral" (La Taille, 2006b, p. 118).

Para testar sua hipótese, La Taille (2006a) realizou uma pesquisa com crianças de 6 a 9 anos de idade. $\mathrm{O}$ autor solicitou aos participantes que atribuíssem sentimentos a personagens injustas e não generosas. Os resultados mostraram que as crianças de 6 anos, em sua grande maioria, atribuem sentimentos positivos à personagem que comete uma injustiça, já que ela conquistou o que queria com tal ato. As mesmas crianças, no entanto, atribuem sentimentos negativos à personagem que falta com a generosidade, concebendo o desconforto 
experimentado por ela. O resultado encontrado nos leva a considerar, portanto, que a generosidade ocupa, sim, um lugar diferenciado no universo moral infantil.

Se a generosidade ocupa um lugar diferenciado no universo moral infantil e, inspirada pela simpatia, é compreendida de forma mais autônoma pela criança pequena, há uma fase anterior de heteronomia nos juízos infantis referentes a essa virtude? Se desde cedo a criança já apresenta sinais de autonomia ao pensar na generosidade, há mudanças evolutivas nos raciocínios infantis sobre as ações generosas? Em outras palavras: a generosidade já se encontra na sua forma mais evoluída desde a mais tenra infância ou podemos admitir uma gênese dessa virtude na criança? Ocupemo-nos dessas questões.

Já vimos que, para Piaget (1932/1994), o realismo moral, característico da heteronomia, é, em parte, produto das relações de coação social, aquelas relações hierárquicas de mandamentos e obediência estabelecidas entre a criança e o adulto que representa a autoridade para ela. Vimos também que a generosidade é inspirada pela simpatia, e o exercício dessa virtude é produto da sensibilidade da criança mais do que de sua disposição para obedecer à autoridade. Podemos, então, afirmar, diante dessas constatações, que os juízos relativos à generosidade não sofrem os efeitos da coação social e, portanto, não apresentam características de uma moral heterônoma? Os dados de uma de nossas pesquisas nos levam a considerar essa hipótese pouco provável.

Nessa pesquisa, colocamos os participantes diante de um conflito entre a possibilidade de manifestar a generosidade e a obediência a uma autoridade (Vale, 2006; Vale \& Alencar, no prelo). Os resultados encontrados nos mostram uma evolução clara das respostas em função da idade: há uma predominância da decisão pela obediência na faixa etária de 7 anos e uma diminuição da mesma opção nas faixas etárias seguintes. Embora a generosidade, inspirada pela simpatia, seja mais bem assimilada do que a justiça por parte das crianças pequenas, ao colocarmos a ação generosa em conflito com a obediência à autoridade, obtemos dados que vão ao encontro dos resultados achados por Piaget (1932/1994) quando contrapôs a justiça ao mesmo elemento em questão. Os dados alcançados pelo autor também apontam para “(...) uma evolução clara em função da idade: os menores pendem para a autoridade e acham mesmo muito justo o que foi mandado à criança (...), enquanto os maiores pendem pela igualdade e acham injusta a ordem descrita na história" (p. 210).

De posse dos resultados encontrados nesse estudo e nas demais pesquisas já comentadas, podemos afirmar que a generosidade é valorizada pela criança pequena, mas, quando essa virtude é contraposta a uma ordem da autoridade, a opção pelo ato generoso tende a cair para o segundo plano. O mesmo não acontece com os adolescentes, que tendem a manter a decisão 
pela generosidade mesmo quando a ação generosa vai de encontro a uma regra estabelecida pelo adulto (Vale, 2006; Vale \& Alencar, no prelo). Essa diferença pode ser explicada pelas características da heteronomia e da autonomia, evidenciadas nas justificativas apresentadas pelos participantes. A obediência cega às regras da autoridade e o medo do castigo, típicos de uma moral heterônoma, podem ser constatados nas justificativas dos participantes de 7 e 10 anos. Grande parte dos entrevistados de 13 anos, contudo, considera que as regras impostas pelo adulto são passíveis de modificação, apresentando, assim, sinais de autonomia moral.

Vejamos um último estudo que realizamos sobre a generosidade, cujos resultados também apontam para uma diferença em função da idade, indicando a possibilidade de mudanças evolutivas nos juízos referentes a essa virtude. Nesse estudo, investigamos se os participantes, ao julgarem se uma pessoa deve ou não ser generosa para com outra, são influenciados pelo tipo de vínculo (amizade ou inimizade) existente entre essas duas pessoas ou pela ausência de vínculo (desconhecido) (Vale, 2006; Vale \& Alencar, 2009). Utilizamos como instrumento uma história-dilema que trazia uma situação escolar cotidiana em que a generosidade poderia ser manifestada para com uma personagem que, inicialmente, foi apresentada como amiga, depois, como desconhecida e, por último, como inimiga. A partir dos resultados encontrados em nosso estudo, podemos afirmar que a ausência de vínculo influencia os juízos da maioria dos participantes de 7 e 10 anos no que diz respeito à intensidade da ação generosa para com o outro. Os entrevistados de 13 anos, contudo, não apresentam a mesma influência em seus juízos sobre a generosidade. A inimizade, por sua vez, influencia os juízos da maior parte dos participantes das três idades pesquisadas.

Mesmo diante de tais dados, ainda poderíamos insistir: a simpatia não deveria garantir às crianças pequenas uma compreensão plenamente autônoma dessa virtude? Não. Concordamos com La Taille (2006b) quando diz que, embora a simpatia seja forte motivação para variados atos generosos, “(...) ela não é nem garantia perene de ações morais, nem sentimento necessário a todas as expressões de moralidade” (p. 116). Além disso, a razão interfere na experiência dessa faculdade afetiva, já que “(...) somente temos simpatia por aquilo que julgamos digno de despertá-la” (p. 116). La Taille ressalta que esse sentimento sofre modificações ao longo do desenvolvimento: “(...) aquilo que comove aos 5 anos poderá não mais comover aos 12 ou aos 20, assim como aquilo que deixa uma criança pequena impassível poderá afetá-la mais tarde" (p. 117). Se a simpatia, que é a base afetiva da generosidade, passa por mudanças no decorrer do desenvolvimento, por que não aconteceria o mesmo com essa virtude? Se a grande motivação para a generosidade pode variar em função 
da idade, por que os juízos relativos a essa virtude não poderiam também sofrer modificações ao longo do desenvolvimento?

A generosidade ocupa sim um lugar diferenciado no universo moral infantil e, inspirada pela simpatia, é compreendida de forma mais autônoma pela criança pequena, mas tais afirmativas não nos levam a afirmar que essa virtude se encontra na sua forma mais evoluída desde a mais tenra infância. A criança já apresenta, desde cedo, sinais de autonomia ao pensar na generosidade, mas isso não significa que ela já tenha uma compreensão plenamente autônoma dessa virtude. A partir de nossas leituras e pesquisas, parece-nos pertinente afirmar que os juízos relativos à generosidade passam sim por mudanças evolutivas.

Os estudos de Eisenberg (1979) nos oferecem contribuições. A autora desenvolveu um modelo teórico de desenvolvimento pró-social, que consiste no processo de aquisição e mudança dos juízos e comportamentos de ajuda dirigidos aos outros. A pró-sociabilidade nos remete em parte à generosidade, já que a sua motivação básica “(...) consiste em beneficiar o outro, sem influências ou pressões externas ou, ainda, sem expectativas de prêmios ou recompensas materiais ou sociais" (Koller \& Bernardes, 1997, p. 224).

Eisenberg (1979), como Piaget (1932/1994) e Kohlberg (1992), fez uso em suas pesquisas de entrevistas clínicas baseadas em histórias-dilema, mas não focalizou os conflitos interpessoais e as transgressões a regras, predominantes nas pesquisas desses autores. Eisenberg produziu um novo enfoque no estudo da moralidade, estudando temas como dividir, ajudar, confortar etc. Nos dilemas propostos pela autora, o papel das proibições, sanções, imposições da autoridade e outros critérios referentes às obrigações formais é minimizado. Os resultados de suas pesquisas a levaram a destacar a presença das atitudes prósociais no universo moral infantil. Eisenberg afirma, inclusive, que essas atitudes são mais precoces nas crianças do que os comportamentos relacionados à justiça.

Koller e Bernardes (1997) compararam o modelo teórico do desenvolvimento pró-social de Eisenberg com o modelo teórico do desenvolvimento do juízo moral de Kohlberg, apontando similaridades e divergências entre as duas teorias. De acordo com as autoras, o maior ponto de concordância entre os dois modelos teóricos consiste no pressuposto básico de que o desenvolvimento moral é limitado pelo nível de complexidade da cognição do indivíduo. Seguindo essa perspectiva, crianças pequenas são incapazes, segundo Eisenberg (1979), de expressar altos níveis de raciocínio moral pró-social.

Outro aspecto similar apontado por Koller e Bernardes (1997) está relacionado ao desenvolvimento do raciocínio moral como um todo. O raciocínio focado em si mesmo e/ ou egoísta é considerado moralmente imaturo nos dois modelos teóricos. Os dois autores 
comparados também propõem como um nível de moralidade intermediária a orientação para a aprovação alheia, com adesão às normas sociais e aos valores, e a orientação auto-reflexiva referente ao bem estar do outro. E um nível relativamente avançado do desenvolvimento moral contempla, nas duas teorias, a preocupação pelos princípios éticos abstratos, os imperativos sociais de consciência e a busca do cumprimento das próprias obrigações.

No que diz respeito às diferenças entre os dois modelos teóricos comparados, Koller e Bernardes (1997) ressaltam que as características pessoais e as experiências de socialização são mais acentuadas no modelo de Eisenberg do que na teoria de Kohlberg. Enquanto este enfatiza a universalidade do desenvolvimento do juízo moral sem privilegiar as diferenças individuais, aquela afirma que o nível de desenvolvimento do raciocínio moral pró-social pode ser determinado por diferentes aspectos que se relacionam diretamente à individualidade do sujeito. "Os fatores evolutivos, o desempenho na esfera da competência e as diferenças individuais fornecem ao modelo teórico de Eisenberg um certo caráter relativista" (Koller \& Bernardes, 1997, p. 232). Além disso, o modelo proposto por Eisenberg, diferentemente da teoria de Kohlberg, não considera que os estágios do desenvolvimento formem um todo estruturado e se apresentem em uma sequência invariante. No modelo teórico da autora, "um indivíduo pode apresentar uma variedade de níveis de raciocínio, expressos por respostas relativas a várias categorias de julgamento moral pró-social ao mesmo tempo" (Koller \& Bernardes, 1997, p. 230).

Koller e Bernardes (1997) finalizam esse estudo comparativo ressaltando que "a área de pesquisa sobre o desenvolvimento moral pró-social, por sua atualidade, está aberta para vários estudos. Ainda que muitas pesquisas já tenham verificado aspectos evolutivos da prósociabilidade, várias questões estão em busca de respostas" (p.250). Nossas pesquisas sobre a generosidade oferecem contribuições para esse campo do conhecimento, mas, em concordância com as autoras, constatamos que ainda há perguntas sem respostas. Apresentaremos algumas delas no capítulo seguinte sobre os objetivos e hipóteses deste projeto. Agora, finalizemos esta seção discutindo uma última questão que propomos.

Se admitimos a inclusão da generosidade na concepção de Piaget (1932/1994) sobre a moral, podemos, a partir dessa perspectiva teórica, defender a tese de Gilligan (1982) sobre a existência de duas orientações morais universais? A psicóloga americana tinha, de certa forma, razão quando mencionou Piaget entre os autores que julgavam as mulheres como inferiores aos homens no que diz respeito à moral. Nos escritos do autor sobre a prática e a consciência das regras nos jogos infantis, há uma passagem que atesta a crítica de Gilligan: “A observação mais superficial foi suficiente para mostrar que, em linhas gerais, as meninas 
têm o espírito jurídico muito menos desenvolvido que os meninos" (Piaget, 1932/1994, p. 69). Mais adiante, todavia, Piaget ressalta que, apesar das diferenças na estrutura dos jogos ${ }^{3}$ e na mentalidade de meninos e meninas, ambos apresentam um mesmo processo de desenvolvimento: “(...) primeiramente, um respeito místico pela lei, tida como intocável e de origem transcendente, depois uma cooperação que liberta os indivíduos de seu egocentrismo prático e introduz uma noção nova e imanente da regra" (p. 74). A partir desse resultado, o autor formulou a hipótese de que o desenvolvimento do juízo moral, que diz respeito às regras propriamente ditas morais, aconteceria da mesma maneira. Sua hipótese foi confirmada nas suas investigações a respeito das concepções infantis sobre os deveres morais.

Para Piaget (1932/1994), não há, portanto, um desenvolvimento moral feminino que difere do desenvolvimento masculino. Em concordância com o autor, e também com Kohlberg (1992), parece-nos válido defender aqui a existência de um único processo de desenvolvimento do juízo moral, tanto para meninos quanto para meninas. Acrescentamos, ainda, que a generosidade, e não somente a justiça, faz parte desse processo. Mas não sejamos inertes às considerações de Gilligan sobre as diferenças de gênero e pensemos: embora admitamos que homens e mulheres passam por um mesmo processo de desenvolvimento, os juízos morais femininos apresentam diferenças em relação aos juízos masculinos?

Autores como Walker (1984) e Lourenço (1991) não consideram que as diferenças entre os sexos têm sido significativas na análise dos aspectos morais. O primeiro autor, após uma revisão crítica da literatura, constatou que as diferenças entre os juízos masculinos e femininos encontradas em algumas pesquisas eram confundidas com o nível de escolaridade e a ocupação profissional dos entrevistados. Lourenço também não encontrou diferenças entre as respostas apresentadas por meninos e meninas no que diz respeito à ética do cuidado e à ética da justiça. Os resultados de uma pesquisa de La Taille (2009b) também nos leva a responder à questão de forma negativa. $\mathrm{O}$ autor submeteu à avaliação moral de alunos de $15 \mathrm{a}$ 18 anos (de escolas pública e particular) a seguinte afirmação: "Hoje as pessoas generosas são mais importantes que as pessoas justas" (p. 63). De acordo com La Taille, 70\% dos entrevistados discordam da afirmativa apresentada, não havendo diferença significativa nos juízos masculinos e femininos a respeito. Na mesma pesquisa, todavia, as associações entre virtudes e gênero estabelecidas pelos próprios participantes parecem seguir, de acordo com o autor, o critério da "conexão com outrem", que nos remete à ética do cuidado proposta por

\footnotetext{
3 Para pesquisar a prática e a consciência da regra na criança, Piaget (1932/1994) fez uso de jogos distintos nas entrevistas com meninos e meninas: utilizou o jogo de bolinhas de gude com eles, e o jogo da amarelinha com elas.
} 
Gilligan (1982). Segundo La Taille, a generosidade, quando não atribuída a ambos os sexos, é privilegiadamente associada às mulheres nesse estudo. Os resultados dessas pesquisas nos apontam possíveis respostas à questão proposta, mas a necessidade de novos estudos se faz presente. Considerar a variável gênero no delineamento de investigações no campo da moral mostra-se relevante, principalmente daquelas dedicadas à generosidade.

Embora tenhamos ressaltado diversas vezes a relevância de novos estudos sobre a generosidade, não pretendemos, aqui, desprezar a justiça como noção incontornável da moralidade. Concordamos com Smith (1759/1999) quando diz que uma sociedade sem justiça acaba por se destruir, enquanto uma sociedade sem benevolência, embora promotora de circunstâncias de vida infelizes, ainda pode se manter. Não nos propomos, ao longo deste capítulo, a assentar a generosidade como superior ou igual à justiça no campo da moral, mas apenas defender a importância de também elegê-la como objeto de investigação da psicologia da moralidade, ampliando essa área do conhecimento para além do tema dos direitos e deveres.

\subsection{A generosidade e a educação moral}

A invisibilidade de outrem aos olhos alheios é, segundo La Taille (2009a), um fenômeno atual e o ensejo de diversos atritos sociais. "Cada um fica centrado em seu pequeno 'universo particular', despreocupado ou inconsciente da presença de outrem e de seus anseios" (p. 201). Nesse contexto, destacamos a importância do sentimento de simpatia, capacidade de se comover com os estados afetivos alheios. Por meio dessa disposição afetiva, que é espontânea e precoce, o outro ganha saliência aos olhos da criança. Mas se a simpatia, conforme já vimos,

já comparece no despertar do senso moral, como chegamos ao fenômeno atual da invisibilidade de outrem aos olhos alheios? Parece-nos válido pensar, com La Taille, que a sociedade atual cause, nas crianças, “(...) uma atrofia da simpatia, que, assim abortada, não desabrocha e priva o sentimento do dever de uma de suas mais importantes bases. Se tal for o caso, devemos repensar a formação moral das novas gerações (...)” (p. 201). Considerando que a simpatia é a base afetiva da generosidade, incluir um trabalho com essa virtude na formação moral de crianças e adolescentes não só impedirá uma possível atrofia dessa disposição afetiva, como poderá “(...) lapidar esse sentimento para que se transforme no 
desejo de fazer um 'dom de si'" (La Taille, 2009a, p. 285). Mas o que se tem feito atualmente para que as crianças cultivem virtudes como a generosidade?

No campo da educação, destacamos o sucesso do Livro das Virtudes, de Bennett (1995). Com o objetivo de contribuir para a tarefa da formação moral, o autor elabora uma coletânea de histórias que ilustram o que é certo e o que é errado, o que é bom e o que é ruim. Essas histórias abordam a moralidade e as virtudes como essência da natureza humana e terminam com uma pequena lição de moral. Nas palavras de Bennett: "Nenhum recurso moderno, nem mesmo a televisão, supera as boas histórias que começam com 'Era uma vez...”' (p. 9).

Como Bennett (1995), acreditamos que histórias, fábulas e contos de fada podem sim ser ricos instrumentos para um trabalho pedagógico que aborde o tema das virtudes. No entanto, concordamos com La Taille (In Cortella \& La Taille, 2005) quando afirma que Bennett, ao determinar a qual virtude cada história se refere, moraliza e normatiza as virtudes ${ }^{4}$. Ora, sabemos que virtudes, como a generosidade, não podem ser impostas ou exigidas, pois concretizam-se por ação espontânea. Além disso, esses valores não possuem significados únicos e rígidos, pois se coordenam de diversas maneiras (La Taille, 2001b). Assim, “(...) impor definições às virtudes é empobrecê-las e, logo, fugir de seu caráter de excelência. Virtudes ‘engessadas' deixam de ser virtudes” (La Taille, 2001b, p. 94).

Dias (2002) também utilizou histórias para realizar um trabalho pedagógico sobre as virtudes generosidade e coragem com crianças de 6-7 anos de idade. A autora, por sua vez, ao contar as histórias aos participantes, retirava partes das narrativas em que as referidas virtudes eram apresentadas de forma explícita e moralista. A lição de moral, presente na maioria das histórias do livro de Bennett (1995), por exemplo, era eliminada dos contos utilizados pela autora. A proposta de Dias era deixar para as crianças o trabalho de reflexão e atribuição de valores às atitudes das personagens. Assim, em uma única história, por exemplo, outras virtudes como justiça e gratidão eram mencionadas pelos participantes. De acordo com La Taille (In Cortella \& La Taille, 2005):

É nessa variedade de interpretações que está a riqueza dos contos. Mas se dizemos à criança, de antemão, que determinada história trata de justiça, que determinada outra fala de generosidade, e assim por diante, empobrecemos sobremaneira a questão das virtudes. Enfim, tratar as virtudes de maneira, digamos, moralista, é negativo (p. 17).

\footnotetext{
${ }^{4}$ Vale ressaltar que a moralização e a normatização das virtudes apontadas por La Taille (2005) nos remete à tendência moralista da educação, que é caracterizada pela imposição pura e simples de valores, sem espaço para reflexões e críticas por parte dos alunos. Esse modelo de formação moral é uma espécie de doutrinação e consiste em levar as crianças a atitudes consideradas corretas de antemão. A famosa lição de moral das histórias exemplifica essa tendência, já que há, nesse caso, a imposição de uma única versão do conto, impedindo que a própria criança reflita sobre os sentidos que pode extrair do texto.
} 
Embora o trabalho com virtudes não corresponda somente aos objetivos dos programas educacionais, a escola parece-nos um ambiente ideal para trabalhar esse tema. A generosidade e as demais virtudes tornam-se uma forma moral de conduta cotidiana na vida das crianças por meio do próprio convívio escolar, da reflexão sobre situações conflitantes, da discussão de problemas e trocas de opiniões, da experiência ética e das relações de cooperação. Nas palavras de La Taille (2009a):

Ao propor que a escola seja, de fato, uma instituição justa, e que, nela, o convívio seja pautado pelo estar com outrem e para outrem, estamos na contramão de uma sociedade que tende a colocar as instituições a serviço de interesses particulares e a privilegiar a competição e a "visibilidade pessoal", em detrimento da cooperação e da solidariedade. Ora, a não ser que se julgue a escola totalmente inócua em termos de influência sobre os valores de seus alunos, não se vê por que não seria útil ela propor formas alternativas de se pensar e experimentar o convívio social (p. 274).

Tognetta (2003; Tognetta \& Assis, 2006) investigou a ação de ambientes escolares na construção da solidariedade, também entendida como generosidade pela autora. Ao apresentar dilemas que envolviam esse valor a crianças de 6 a 7 anos de duas escolas diferentes, Tognetta verificou que as respostas dos alunos advindos do ambiente cujas relações baseiamse na cooperação foram mais propensas à solidariedade do que as respostas dos alunos do ambiente cujas relações são baseadas na coerção.

Embora pesquisas como esta demonstrem a importância das relações de cooperação, muitas escolas preferem manter um ambiente coercitivo diante das encruzilhadas do trabalho diário com seus alunos. No entanto, mesmo com a imposição severa de regras e limites restritivos, a agressividade, o desrespeito e a violência por parte dos estudantes não deixam de existir nessas instituições. A indisciplina, por exemplo, tem sido recorrente na prática dos protagonistas escolares. La Taille (2001b) acredita que os atos indisciplinados dos alunos, uma das principais reclamações dos professores atualmente, estão mais relacionados à falta de projetos de vida do que à ausência de firmeza e ordem. E virtudes como a generosidade ampliam os valores que inspiram as respostas dos estudantes para as perguntas sobre tais projetos, portanto, enriquecem o campo da educação moral (La Taille, 2001b).

Quando falamos em educação moral, não estamos nos referindo à velha disciplina Educação Moral e Cívica, já eliminada dos currículos escolares. Entre as novas estratégias de educação e intervenção moral, destacamos a transversalidade, proposta pelos Parâmetros Curriculares Nacionais - PCNs (Brasil, 1997), que se destinam ao ensino fundamental. Transversalizar um tema é trabalhá-lo de forma articulada com todas as disciplinas, ao invés 
de reservar um horário específico para esse fim (Brasil, 1997). Tal proposta resgata a importância do convívio escolar e traz a ética como um dos temas transversais (os demais são: saúde, orientação sexual, meio ambiente, pluralidade cultural, trabalho e consumo). Os PCNs definem quatro blocos de conteúdo para o ensino da ética: respeito mútuo, justiça, diálogo e solidariedade. É útil saber que o enfoque dado ao tema da solidariedade nesse documento aproxima-se da ideia de generosidade, já que, ao discorrerem sobre esse valor, referem-se a uma doação ao outro, a uma ajuda desinteressada.

Apesar dos PCNs colocarem em cena a dimensão da ética na formação escolar, não apresentam uma proposta educacional concreta para a construção dos valores destacados, mas apenas diretivas gerais que podem inspirar pedagogicamente as escolas que assim o desejarem. La Taille et al. (2004), ao pesquisarem propostas pedagógicas de formação ética dos alunos na literatura educacional de 1990 a 2003, encontraram apenas dois artigos que sugerem práticas educacionais relacionadas a esse tema. Nas palavras dos autores: "Discutese bastante, propõe-se muito pouco" (p. 103).

Se acreditamos que a generosidade enriquece o campo da educação moral, parece-nos pertinente, então, elaborar propostas pedagógicas que possam favorecê-la. Mas como podemos tornar esse valor sensível ao pensamento dos alunos? É o último ponto que devemos analisar.

Segundo Piaget (1931/1998), os educadores devem entender que o ensino precisa ser oferecido de acordo com a evolução dos interesses da criança, visto que uma prática educativa só terá alcance se responder a uma necessidade e corresponder a realidades experimentadas e espontaneamente vividas pelo próprio aluno. De acordo com o autor: "Deve-se conduzir a criança do individual para o universal. E o único meio de fazê-lo é 'dirigir a natureza obedecendo-lhe', ou seja, utilizar a psicologia da criança" (pp. 76 e 77). Piaget (1930/1996) ressalta que "sem uma psicologia precisa das relações das crianças entre si e delas com os adultos, toda discussão sobre os procedimentos de educação moral resulta estéril" (p. 2).

Antes de dedicarmo-nos à elaboração de uma proposta de educação moral que favoreça a construção do valor da generosidade, faz-se necessário, portanto, debruçarmo-nos sobre a singularidade dessa virtude e investigar o seu lugar no universo moral infantil. Propomo-nos, aqui, a dar continuidade às nossas pesquisas sobre a generosidade, investigando, em um contexto psicogenético, os juízos morais das crianças relativos aos seguintes temas: a generosidade em contraposição à justiça (para consigo mesmo); generosidade e gratidão. Nos capítulos seguintes trataremos de cada tema separadamente, apresentando os objetivos, as hipóteses, o método, os resultados e as discussões correspondentes. 


\section{ESTUDO 1: A GENEROSIDADE EM CONTRAPOSIÇÃO À JUSTIÇA (PARA CONSIGO MESMO)}

\subsection{Objetivo e hipótese}

Vimos anteriormente que, em uma de nossas pesquisas, a maioria dos participantes de todas as idades pesquisadas (7, 10 e 13 anos) opta pela generosidade em detrimento da satisfação de um interesse próprio (Vale, 2006; Vale \& Alencar, 2008a). Diante desse resultado, propomos uma nova questão: Se a ação generosa, ao invés de implicar na abdicação de um desejo particular, implicasse em um forte prejuízo pessoal, obteríamos também porcentagens altas de respostas de generosidade em todas as idades? Ou essas porcentagens sofreriam variações e encontraríamos uma possível gênese nos juízos dos participantes de diferentes faixas etárias? Foram essas perguntas que nos inspiraram a formular o objetivo deste estudo: investigar, em um contexto psicogenético, os juízos dos participantes sobre situações hipotéticas em que a possibilidade de manifestar a generosidade para com o outro pressupõe um forte prejuízo pessoal. Se considerarmos que, ao implicar em um forte prejuízo pessoal, a manifestação de generosidade implica, de certa forma, em uma injustiça para consigo mesmo, estamos diante, nessas situações hipotéticas, de um conflito entre a generosidade e a justiça. Esperamos averiguar, dessa forma, que lugar a generosidade ocupa no universo moral infantil em contraposição à justiça (para consigo mesmo).

A partir dessa consideração e dos resultados das pesquisas já apresentadas, podemos fazer a hipótese de que a criança pequena, perante esses dois elementos morais conflitantes, tenderá a decidir pela generosidade em detrimento da justiça (para consigo mesma). A justiça passará, assim, a prevalecer paulatinamente sobre a generosidade no decorrer do desenvolvimento. Conheçamos as ideias que nos levam a tal hipótese.

Sabemos que, no início da gênese da moralidade, a noção de justiça não é inteiramente concebida pela criança. Nessa fase, é justo todo ato que revela uma obediência às regras impostas pela autoridade (Piaget, 1932/1994). A descrição que Piaget faz do universo moral infantil é coerente com a sua leitura do desenvolvimento cognitivo. A noção de justiça pressupõe relações de reciprocidade e o conceito de igualdade no sentido da relatividade 
(equidade). Para Piaget (1972/1983), a reciprocidade, por exemplo, implica reversibilidade ${ }^{5}$, característica do pensamento operatório-concreto, que ocorre por volta dos 7-8 anos de idade. Como poderia, então, a criança pré-operatória ter uma compreensão autônoma da justiça se ainda lhe faltam operações mentais necessárias para tanto? A generosidade, por sua vez, não pressupõe, necessariamente, reciprocidade e igualdade e está mais relacionada à sensibilidade da criança do que à sua disposição para obedecer às ordens de um adulto. Inspirada pela simpatia, a generosidade é mais espontânea, o que favorece uma compreensão mais autônoma dessa virtude pela criança pequena. Considerando que, na situação hipotética proposta, não há uma autoridade a quem a criança deva obediência, estamos inclinados a admitir a plausibilidade de nossa hipótese: a criança mais nova tenderá a privilegiar a ação generosa em detrimento da justiça, mesmo em se tratando da justiça para consigo mesma.

Concordamos com La Taille (2006a) quando diz que, no início do desenvolvimento moral, a generosidade abre o caminho “(...) para as relações de reciprocidade sobre as quais repousam os ideais de justiça (p. 14)”. Acrescentamos aqui a hipótese de que, uma vez concebida e livre da subordinação à autoridade, é a noção de justiça que passará a regular a generosidade. A ação generosa permanecerá valorizada pela criança no decorrer do desenvolvimento, mas, ajustada pela justiça, será submetida a uma análise de suas implicações e de seus limites. Se nossa hipótese estiver correta, encontraremos uma possível gênese nos juízos dos participantes de diferentes faixas etárias. A justiça tenderá a prevalecer, progressivamente, nos juízos referentes à situação apresentada.

Vejamos, agora, o método que utilizamos para alcançar o objetivo proposto.

\subsection{Método}

\subsubsection{Participantes}

Participaram deste estudo 60 alunos de uma escola particular da cidade do Rio de Janeiro RJ, com 6, 9 e 12 anos, igualmente divididos quanto ao sexo e à idade.

\footnotetext{
5 Na teoria piagetiana, reversibilidade é a capacidade de realizar a mesma ação nos dois sentidos do percurso, mas tendo consciência de que se trata da mesma ação (Montangero \& Maurice-Naville, 1994/1998).
} 
Como nosso estudo está relacionado a um interesse psicogenético, consideramos relevante entrevistar crianças com 6 anos de idade, já que estas, de acordo com a teoria piagetiana, provavelmente, apresentam uma estruturação cognitiva pré-operatória e, possivelmente, se encontram na fase da heteronomia. É plausível que os participantes de 12 anos já apresentem características de um pensamento operatório formal e, possivelmente, da fase da autonomia. A idade de 9 anos é intermediária entre as duas outras idades investigadas e mostra-se útil para obtermos uma descrição mais adequada das respostas dos participantes em diferentes momentos do desenvolvimento e, também, para analisarmos como alguns tipos de respostas vão se sucedendo a outros.

O sexo dos participantes também foi utilizado como critério de seleção, já que, conforme vimos anteriormente, essa variável tem proporcionado importantes discussões no campo da moralidade. Embora o estudo da influência do sexo no desenvolvimento moral não faça parte de nossos objetivos, decidimos entrevistar o mesmo número de meninos e meninas para anular os possíveis efeitos da variável em questão nos objetivos por ora propostos. Além disso, tal delineamento poderá viabilizar esse tipo de análise posteriormente.

Com base nas variáveis mencionadas, os participantes foram selecionados por meio de um sorteio na própria instituição de ensino.

\subsubsection{Instrumentos e procedimentos}

Antes de iniciarmos a coleta de dados, submetemos nossa proposta de pesquisa ao Comitê de Ética em Pesquisa com Seres Humanos (CEPH) do Instituto de Psicologia da Universidade de São Paulo (IPUSP), que nos concedeu a aprovação (Apêndice A). Encaminhamos, em seguida, um pedido de autorização para o diretor da escola onde foi realizada a pesquisa (Apêndice B). Por fim, os pais ou responsáveis legais dos alunos sorteados foram solicitados a assinar, em duas vias, um termo de consentimento da participação de seus filhos na pesquisa (Apêndice C).

Cumpridos tais procedimentos, realizamos entrevistas individuais com os participantes de acordo com o método clínico proposto por Piaget (1926/s.d.; 1932/1994). Segundo Delval (2002):

O método clínico é um procedimento de coleta e análise de dados para

o estudo do pensamento da criança (embora também se aplique ao 
estudo do pensamento dos adultos) que se realiza mediante entrevistas ou situações muito abertas, nas quais se procura acompanhar o curso do pensamento do sujeito ao longo da situação, fazendo sempre novas perguntas para esclarecer respostas anteriores. Consta, portanto, de algumas perguntas básicas e de outras que variam em função do que o sujeito vai dizendo e dos interesses que orientam a pesquisa que está sendo realizada (p. 12).

Delval (2002) ressalta que esse método foi mais utilizado e deu melhores resultados em estudos que o aplicaram em participantes de diferentes idades. Tais estudos analisaram como o pensamento muda com a idade e como se constroem as ideias. Como nos propomos a pesquisar a gênese dos juízos relacionados à generosidade e, para tanto, entrevistar participantes de três idades diferentes, consideramos o método clínico o recurso metodológico mais adequado para atingir os objetivos de nossa investigação.

Utilizamos como instrumentos histórias que abordam situações hipotéticas em que a manifestação de generosidade para com o outro implica em um forte prejuízo pessoal, ou seja, em uma injustiça para consigo mesmo. Na primeira história, a ação generosa pressupõe um prejuízo escolar e, na segunda, uma perda material.

Eis as histórias seguidas das questões de investigação:

\section{História 1}

Tiago precisava fazer um trabalho de ciências muito difícil para entregar à sua professora no dia seguinte, sem falta. A partir desse trabalho, a professora avaliaria o seu desempenho na disciplina de ciências. Quando Tiago estava começando a fazer o trabalho, tocou a campainha de sua casa. Era Rafael, que pedia a Tiago para ajudá-lo a estudar para uma prova de matemática, que também aconteceria no dia seguinte. Tiago tinha facilidade para resolver as atividades de matemática, mas, se ajudasse Rafael, não teria tempo de fazer o seu trabalho de ciências.

O que você acha que o Tiago deve fazer? Por quê?

Versão feminina: Tatiana e Rafaela

História 2 (versão masculina)

Márcio participou de um campeonato de futebol na sua rua, e seu time venceu. Cada jogador foi premiado com um MP3. Quando estava voltando para casa, Márcio encontrou Antônio chorando porque um ladrão roubou o MP3 que ganhou de presente de aniversário. Os pais 
de Antônio trabalharam muito para conseguir comprar esse presente e não tinham mais dinheiro para comprar outro MP3 para ele.

O que você acha que o Márcio deve fazer? Por quê?

História 2 (versão feminina - 6 e 9 anos)

Márcia participou de um campeonato de queimada na sua rua, e seu time venceu. Cada jogadora foi premiada com um MP3. Quando estava voltando para casa, Márcia encontrou Aline chorando porque um ladrão roubou o MP3 que ganhou de presente de aniversário. Os pais de Aline trabalharam muito para conseguir comprar esse presente e não tinham mais dinheiro para comprar outro MP3 para ela.

O que você acha que a Márcia deve fazer? Por quê?

História 2 (versão feminina - 12 anos)

Márcia participou de um campeonato de vôlei na sua rua, e seu time venceu. Cada jogadora foi premiada com um MP3. Quando estava voltando para casa, Márcia encontrou Aline chorando porque um ladrão roubou o MP3 que ganhou de presente de aniversário. Os pais de Aline trabalharam muito para conseguir comprar esse presente e não tinham mais dinheiro para comprar outro MP3 para ela.

O que você acha que a Márcia deve fazer? Por quê?

Durante a coleta de dados, todas as personagens foram apresentadas com o mesmo sexo do participante entrevistado no momento, por isso temos uma versão masculina e outra feminina de todas as histórias. Vale destacar que empregamos linguagem apropriada para a idade de cada entrevistado a fim de que as histórias e as questões de investigação fossem compreendidas com maior facilidade. De acordo com Piaget (1932/1994), "quando empregamos a psicologia, é preciso falar às crianças como elas falam entre si, senão a prova de avaliação moral se transforma numa prova de inteligência ou de compreensão verbal" (p. 100). 
A coleta de dados foi realizada em uma sala de aula vazia na própria escola dos participantes da pesquisa. Todas as entrevistas foram gravadas na íntegra e, em seguida, transcritas pela própria entrevistadora.

\subsubsection{Tratamento dos dados}

Priorizamos a análise qualitativa dos dados encontrados e utilizamos uma referência quantitativa, em termos de percentuais, que nos auxiliou na apresentação e discussão dos resultados.

Inicialmente, transcrevemos as 60 entrevistas, cujos protocolos se encontram no Apêndice D, em CD digitalizado. Em seguida, realizamos a leitura dos protocolos para, então, iniciarmos a categorização dos dados.

Primeiramente, elaboramos categorias detalhadas (microcategorias) para as respostas e justificativas dos participantes. Em seguida, listamos todas as categorias detalhadas e agrupamo-las em categorias resumidas (macrocategorias). Obtivemos, assim, um sistema de categorias resumidas e detalhadas para cada questão de investigação. Como nos propomos a um objetivo psicogenético, cruzamos as categorias resumidas com as idades dos participantes da pesquisa.

Conheçamos, agora, os resultados encontrados.

\subsection{Resultados e discussão}

\subsubsection{História 1}

Vimos que, na primeira história, a ajuda ao outro pressupõe um prejuízo escolar: Deve a personagem em conflito ajudar um colega em dificuldade a estudar para a prova de matemática e, para tanto, abdicar de fazer o seu trabalho de ciências? Ou deve a personagem negar ajuda a esse colega e, assim, se dedicar ao próprio trabalho? Eis o dilema que apresentamos aos nossos participantes. 
A grande maioria deles (85\%) respondeu que a personagem não deve ajudar o colega, mas fazer o trabalho que é de sua responsabilidade. Ressaltamos, porém, que essa solução não foi simples nem óbvia para a maior parte dos entrevistados. Muitos deles mudaram suas respostas ao longo da entrevista, outros expressaram a dificuldade que sentiram para hierarquizar as dimensões do problema proposto: "Foi uma decisão entre a cruz e a espada. Você não sabe o que escolher. Porque eи quero sempre me sair bem na escola, mas também não quero que o amigo fique reprovado, boiando na matéria" (Leonardo, $12 ; 8)^{6}$. O mal estar previsto por alguns na tomada de decisão da personagem demonstra que as duas opções em jogo tinham um peso moral relevante: "Eu me sentiria mal, mas eu escolheria o trabalho. Se eu o ajudasse, eu tiraria zero, se eu não o ajudasse, ele tiraria zero. Eu me sentiria muito mal, mas...” (João, 12; 1).

Destacamos, ainda, que quase metade dos participantes (45\%) tentou, inicialmente, conciliar as duas dimensões conflitantes. Essa tentativa de conciliação também já apareceu nos resultados de outras pesquisas com dilemas que envolviam a generosidade (Tognetta, 2003; Tognetta \& Assis, 2006; Vale, 2006; Vale \& Alencar, 2008a; Vale \& Alencar, no prelo). Aqui, uma das alternativas propostas pelos entrevistados foi fazer uma atividade seguida da outra. A personagem em conflito deveria ajudar o colega a estudar e, em seguida, fazer o próprio trabalho ou vice-versa:

Ela poderia ajudar a amiga mais ou menos metade do horário dela e, no outro horário, ela poderia fazer o trabalho dela. Mas, aí, ela teria que ajudar, digamos, rápido. Só tirar as dúvidas da amiga e pronto. Depois, ela iria fazer o trabalho dela (Joana, 9; 7).

A possibilidade das duas personagens fazerem as duas tarefas juntas também foi apresentada como uma opção para a resolução do dilema:

Eu acho o seguinte. O Rafael poderia ficar na casa do Tiago, o Tiago o ajudaria e, logo depois do estudo, ele veria se o Rafael poderia ajudálo no trabalho de ciências. Se eu fosse o Tiago, eu faria isto: "Cara, eu te ajudo para a prova de amanhã, vamos ficar mais ou menos uma hora e meia estudando e, depois, você me ajuda no trabalho. Tudo bem?" (João, 12; 1).

\footnotetext{
${ }^{6}$ Todas as vezes que citarmos a resposta ou a justificativa de um participante, apresentaremos, em seguida, um nome próprio e dois números separados por ponto-e-vírgula, ambos entre parênteses. O primeiro dado diz respeito ao nome fictício do entrevistado para não comprometermos o seu anonimato. Já os números representam a idade do participante em anos e meses. Assim, "12; 8" indica 12 anos e 8 meses de idade.
} 
Alguns entrevistados até se dispuseram a um certo sacrifício para não precisar escolher entre as duas opções: "Se ele fizer as questões no dia seguinte bem cedo, de madrugada, ele vai conseguir fazer o trabalho. Mas ele vai ficar muito cansado. Mas é o único jeito de fazer para os dois" (Fábio, 6; 4).

Diante das mais diversas alternativas propostas pelos participantes, apresentamos contraargumentações e mostramos a impossibilidade da conciliação que propunham. Ressaltamos que o tempo que a personagem em conflito dispunha não era suficiente para fazer as duas tarefas em jogo e os deixamos cientes de que a disciplina relativa ao trabalho diferia da disciplina concernente à prova, o que dificultaria uma atividade em conjunto. Perante essas colocações, os entrevistados não encontraram outra alternativa senão escolher um dos elementos morais contrapostos e, nesse caso, a decisão da maioria culminou em não ajudar o colega em dificuldade.

Conheçamos agora a distribuição das respostas de acordo com as faixas etárias pesquisadas, já que nossa proposta está relacionada a um interesse psicogenético. Conforme podemos observar na Figura 1, a opção por não ajudar o colega prevalece em todas as idades, não havendo, assim, uma gênese referente a essa questão. Vale lembrar que, anteriormente, levantamos a hipótese de que a generosidade e, portanto, a decisão de auxiliar quem estava com dificuldade, deveria prevalecer nos juízos das crianças mais novas. Ora, não é isso que os dados nos mostram. Como explicá-los então?

Vimos que a ação generosa é valorizada pela criança pequena, já que, diante de um conflito entre a generosidade e a satisfação de um interesse próprio, ela tende a optar pela virtude (Vale, 2006; Vale \& Alencar, 2008a). Quando contraposta a uma ordem imposta pela autoridade, todavia, a generosidade tende a cair para o segundo plano nos juízos infantis (Vale, 2006; Vale \& Alencar, no prelo). A situação hipotética deste estudo não traz um conflito entre o ato generoso e a obediência à autoridade, mas aqui a virtude também perde para a outra dimensão do dilema. Por quê? 


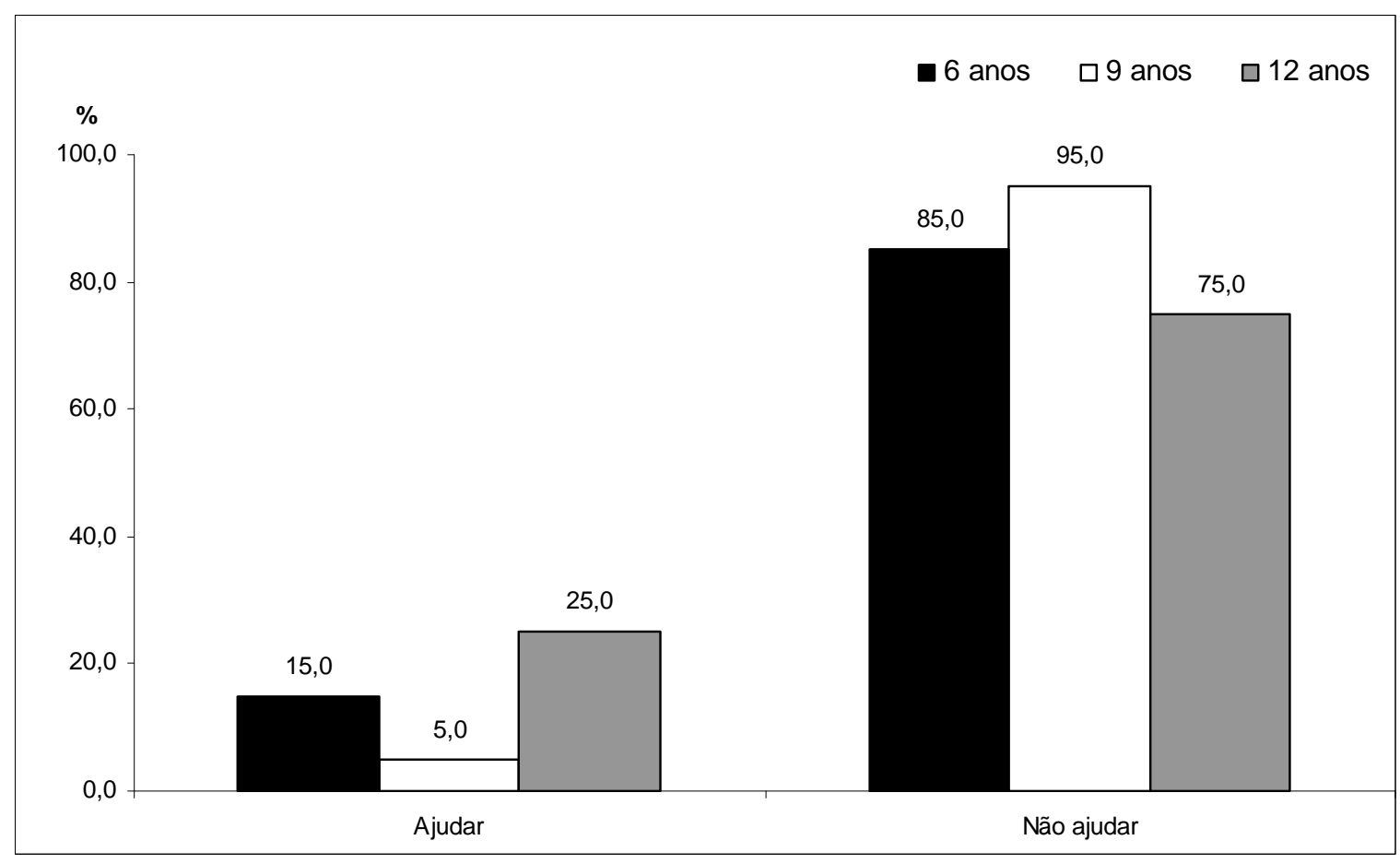

Figura 1. Generosidade em contraposição à justiça (para consigo mesmo) - história 1: comparação das respostas dos participantes conforme a idade.

É verdade que, na presente situação, a generosidade não está em conflito direto com a ordem de um adulto a quem a criança deva obediência, mas atentemo-nos ao conteúdo da história e verifiquemos se a autoridade não está implícita nesse dilema. A quem o trabalho de ciências da personagem em conflito deveria ser entregue? E quem avaliaria esse trabalho? A resposta a ambas as perguntas é a mesma: a professora, uma importante autoridade para a criança em idade escolar. Se a dimensão contraposta à generosidade nos remete, mesmo que indiretamente, a uma figura de autoridade, podemos afirmar que é à justiça (para consigo mesma) que as crianças mais novas visam quando decidem não ajudar o colega? É a justiça que está em jogo quando essas crianças abdicam da generosidade? Se a resposta for positiva, somos forçados a abandonar nossa hipótese de que a justiça perde para a generosidade nos juízos das crianças mais novas. Mas pensemos na possibilidade de uma resposta negativa. Para tanto, façamos como Piaget e Kohlberg e não nos contentemos com o veredicto. Conheçamos as razões que levaram a maioria de nossos participantes a negarem ajuda ao colega em dificuldade (Tabela 1$)^{7}$.

\footnotetext{
${ }^{7}$ É importante saber que muitos participantes apresentaram mais de uma razão para suas respostas, por isso o número total de justificativas é superior a quantidade de entrevistados.
} 
Tabela 1

Generosidade em contraposição à justiça (para consigo mesmo) - história 1: distribuição conforme a idade das justificativas dos participantes que decidiram não ajudar o outro

\begin{tabular}{lcccccccc}
\hline \multirow{2}{*}{ Justificativa } & \multicolumn{2}{c}{6 anos } & \multicolumn{2}{c}{9 anos } & \multicolumn{2}{c}{12 anos } & \multicolumn{2}{c}{ Geral } \\
\cline { 2 - 9 } & $\mathrm{N}^{\mathbf{0}}$ & $\%$ & $\mathrm{~N}^{\mathrm{o}}$ & $\%$ & $\mathrm{~N}^{\mathrm{o}}$ & $\%$ & $\mathrm{~N}^{\mathrm{o}}$ & $\%$ \\
\hline Consequências da decisão & 13 & 76,5 & 16 & 84,2 & 5 & 33,3 & 34 & 66,7 \\
$\begin{array}{l}\text { A justiça (para consigo mesmo) } \\
\text { deve preceder à generosidade }\end{array}$ & 2 & 11,8 & 3 & 15,8 & 8 & 53,3 & 13 & 25,5 \\
$\begin{array}{l}\text { Circunstâncias atenuantes } \\
\begin{array}{l}\text { A generosidade pode ser delegada } \\
\text { a outrem }\end{array}\end{array}$ & 3 & 17,6 & 2 & 10,5 & 7 & 46,7 & 12 & 23,5 \\
\hline
\end{tabular}

$\mathrm{Na}$ Tabela 1, podemos verificar que $66,7 \%$ dos participantes que optaram por não ajudar o colega em dificuldade mencionaram as consequências da decisão como justificativa para suas respostas. A maioria das consequências citadas alude a possíveis prejuízos escolares decorrentes do ato generoso. Entre os prejuízos escolares, a nota baixa, inclusive o zero, foi a mais mencionada pelos nossos entrevistados: "Porque, se ela parar, a tia não vai dar a nota para ela. Se ela não entregar, vai ficar sem a nota, com nota baixa no trabalho" (Marina, 9; 8). Muitos deles acrescentaram a reprovação escolar resultante da nota ruim para justificar a decisão por não ajudar o colega: “(...) ele poderia tirar nota baixa e poderia até repetir o ano" (Carlos, 9; 6). Alguns participantes fizeram referência à nota do trabalho como uma consequência positiva da recusa à ajuda ao colega: "Para ele tentar tirar uma nota boa. Porque o trabalho vale nota" (Bruno, 6; 5). Por fim, o medo da bronca da professora aparece nas justificativas de alguns poucos entrevistados de 6 e 9 anos: "Porque, senão, a professora, no dia seguinte, brigaria com ele, e não com o Rafael" (Juliana, 9; 3).

Os exemplos citados para ilustrar os tipos de respostas incluídas nessa categoria nos remetem ao início do desenvolvimento moral da criança. Encontramos aqui justificativas hedonistas, características do nível pré-convencional de Kohlberg (1992) e o medo da punição (ou da bronca da professora) da moral heterônoma, que não constituem reais argumentos de justiça. Se voltarmos à Tabela 1, verificaremos que esta foi a justificativa mais utilizada pelos participantes de 6 e 9 anos que optaram por não ajudar aquele que estava com dificuldade. Esse resultado nos leva a responder a pergunta apresentada anteriormente de forma negativa: não é a justiça (para consigo mesmo) que está em primeiro plano quando os entrevistados mais novos de nosso estudo abdicam da generosidade para com o outro. Pelo menos é o que seus argumentos nos induzem a crer. 
Ao contrário do que supúnhamos, as crianças mais novas não privilegiam a generosidade diante da situação hipotética apresentada, mas, conforme conjeturamos, também não é a noção de justiça que assume tal privilégio. Fizemos ainda a hipótese de que a justiça (para consigo mesmo) prevaleceria nos juízos dos participantes mais velhos. E, de fato, $75 \%$ deles optaram por não ajudar o colega em dificuldade. Mas ainda cabe a pergunta: é à justiça que vislumbram nossos entrevistados de 12 anos quando decidem abdicar da generosidade? Voltemos à Tabela 1 para responder à questão.

Uma das categorias de justificativa predominantes na maior faixa etária de nosso estudo é: a justiça (para consigo mesmo) deve preceder à generosidade. Mais da metade dos participantes de 12 anos (53,3\%) justificou dessa forma sua opção por não ajudar o outro. Nas palavras de Elisa $(12 ; 4)$ :

Porque ela tem que fazer o trabalho dela, é a nota dela. Se ela fosse ajudar outra pessoa, ela se prejudicaria. Ela deve ajudar o outro, mas ela não pode esquecer que ela também é importante, mais importante até do que o outro.

Como o próprio nome da categoria indica, a justiça (para consigo mesmo) parece sim ter sido utilizada como critério para que nossos entrevistados de 12 anos renunciassem à generosidade. Atenção: as consequências da decisão também são citadas nas justificativas dessa categoria, mas há uma notável diferença em relação à categoria anterior. Aqui, os participantes não fazem uma simples avaliação de uma ação particular, mas vinculam seus juízos a um princípio geral. Aqui, o auto-interesse também está em jogo (e por que não deveria estar?), mas submetido à noção de justiça (para consigo mesmo), que, para esses participantes, deve sim ser anterior à generosidade: “(...) e, antes de tudo, ele precisa pensar nele para depois, poder ajudar o próximo” (Breno, 12; 5). Como diz Comte-Sponville (1995/1997): "Devemos renunciar a nosso próprio interesse? Claro que não. Mas devemos submetê-lo à justiça, e não o contrário" (p. 78). Não é o que buscam fazer tais entrevistados? Parece-nos pertinente responder que sim.

Prossigamos com a análise das categorias da Tabela 1. Uma outra justificativa que se destaca na faixa etária de 12 anos é circunstâncias atenuantes, utilizada por quase metade dos entrevistados mais velhos que optaram por não ajudar o outro $(46,7 \%)$.

A maior parte dos participantes dessa categoria ressaltou as circunstâncias relativas à personagem que carecia de ajuda, atribuindo-lhe responsabilidade pela situação em que se encontrava e/ ou pela resolução do próprio problema: 
O Tiago deve dizer para o Rafael: "Rafael, você deveria ter pegado o livro de matemática para estudar porque eu não posso te ajudar agora porque eu estou fazendo o trabalho de ciências”. (...) se o Rafael tivesse pegado o livro de matemática, não teria atrapalhado o Tiago. $O$ Rafael deveria ter trazido o livro de matemática para poder estudar porque o Rafael estava atrapalhando o Tiago na hora em que ele precisava de mais concentração (Carlos, 9; 6).

Esse tipo de justificativa nos faz lembrar da fábula A cigarra e a formiga (Lobato, 1987): enquanto a formiga trabalhava de forma incessante durante o verão para guardar alimentos, a cigarra cantava alegremente. No inverno, a cigarra, apavorada com o frio e as chuvas, pede socorro à formiga que tanto labutou na estação quente do ano, e ela lhe responde: "Você cantava? Que beleza! Pois, então, dance agora!” (Lobato, 1987, p. 171). Se a cigarra houvesse trabalhado como a formiga durante o verão, não estaria em apuros no inverno. Da mesma forma, segundo esses participantes, se a personagem em dificuldade houvesse estudado mais, esclarecido suas dúvidas com a professora ou até mesmo pedido ajuda com maior antecedência, ela não se encontraria nas atuais circunstâncias. Como não o fez, deve arcar com as consequências. Não estamos falando aqui da justiça retributiva? Parece-nos válido responder que sim. Ousaríamos, inclusive, relacionar tais argumentos a um dos tipos de sanção por reciprocidade mencionado por Piaget (1932/1994), já que é sugerido que a personagem suporte e/ ou resolva as implicações de seu ato.

La Taille, Domingues, Jamra e Fiorini (1999), ao pesquisarem sobre as virtudes morais segundo as crianças, fizeram uso da referida fábula em entrevistas com participantes de 6 e 9 anos. A grande maioria dos entrevistados julgou que a formiga deve ajudar a cigarra, mesmo que esta não se mostre merecedora de tal atitude. A generosidade, nesse caso, prevaleceu sobre a justiça. Em nossa pesquisa, embora esse tipo de justificativa predomine na idade de 12 anos, é também encontrado nas menores faixas etárias do estudo.

Continuemos com a apresentação da categoria circunstâncias atenuantes. Aqui, há também referência às condições relativas à personagem em conflito: “(...) porque ele também estava precisando de nota. Porque é uma nota importante para ele” (Breno, 12; 5). Alguns participantes de 12 anos não só mencionaram as condições de ambas as personagens como estabeleceram uma comparação entre elas para, então, efetuarem suas escolhas: "Se ele fosse ajudar o amigo, ele não faria nada do trabalho. O amigo ainda teria a chance de tirar uma nota boa, mesmo não sendo muito bom em matemática” (Daniel, 12; 6). Breno, ao julgar que a personagem em conflito não deveria ajudar o colega em dificuldade, leva em conta a situação particular dessa personagem. Como poderia ajudar um colega a conseguir uma boa 
nota na prova se ela mesma precisava, naquele exato momento, fazer um trabalho para adquirir sua própria nota? Daniel vai além: pensa nas condições particulares de ambas as personagens para avaliar e pesar as implicações das opções em jogo e, finalmente, toma sua decisão procurando reduzir danos e efeitos colaterais. Ora, não estamos aqui no campo da justiça distributiva? O raciocínio de Daniel nos remete, inclusive, a sua forma mais evoluída, a equidade.

Como vimos, a análise das diferentes justificativas que compõem a categoria circunstâncias atenuantes nos remete, de alguma forma, à noção de justiça. Considerando que a porcentagem relativa à idade de 12 anos se destaca quando comparada as demais faixas etárias do estudo, mais uma vez, nossos dados vão ao encontro de nossa hipótese: os participantes mais velhos não privilegiam a generosidade diante do dilema moral proposto e, conforme conjeturamos, é a justiça (para consigo mesmo) que assume tal privilégio.

Vale dizer ainda que $27,4 \%$ dos participantes que optaram por não ajudar o colega mencionaram que a generosidade pode ser delegada a outrem: “(...) porque ela também poderia pedir ajuda a outra pessoa que também fosse boa em matemática” (Joana, 9; 7). Muitos entrevistados fizeram referência a uma autoridade (pai, mãe ou professora) ao delegarem a ação generosa: "O problema é que quem tem que ajudar é a mãe. A Tatiana é uma coleguinha. A mãe é quem tem que ajudar em tudo" (Tatiana, 6; 2). É importante ressaltar que a menção à autoridade prevalece na faixa etária de 6 anos e diminui nas faixas de idade seguintes, o que ilustra, mais uma vez, a importância da figura adulta no início do desenvolvimento moral da criança.

Conheçamos, agora, quais os critérios utilizados pelos poucos participantes que julgaram que a personagem em conflito deveria ajudar o colega em dificuldade (Tabela 2) ${ }^{8}$.

\footnotetext{
${ }^{8}$ Aqui, o número total de justificativas também é superior a quantidade de entrevistados, visto que alguns deles apresentaram mais de uma razão para suas respostas.
} 
Tabela 2

Generosidade em contraposição à justiça (para consigo mesmo) - história 1: distribuição conforme a idade das justificativas dos participantes que decidiram ajudar o outro

\begin{tabular}{lcccccccc}
\hline \multirow{2}{*}{ Justificativa } & \multicolumn{2}{c}{6 anos } & \multicolumn{2}{c}{9 anos } & \multicolumn{2}{c}{12 anos } & \multicolumn{2}{c}{ Geral } \\
\cline { 2 - 9 } & $\mathrm{N}^{\mathrm{o}}$ & $\%$ & $\mathrm{~N}^{\mathrm{o}}$ & $\%$ & $\mathrm{~N}^{\circ}$ & $\%$ & $\mathrm{~N}^{\circ}$ & $\%$ \\
\hline Circunstâncias atenuantes & 3 & 100,0 & 0 & 0,0 & 1 & 20,0 & 4 & 44,4 \\
Amizade & 2 & 66,7 & 0 & 0,0 & 4 & 80,0 & 6 & 66,7 \\
Reciprocidade pragmática & 0 & 0,0 & 1 & 100,0 & 2 & 40,0 & 3 & 33,3 \\
Outros & 0 & 0,0 & 0 & 0,0 & 1 & 20,0 & 1 & 11,1 \\
\hline
\end{tabular}

A categoria circunstâncias atenuantes também aparece entre os participantes que decidiram ajudar o outro. Mas, na Tabela 2, é a menor faixa etária do estudo que ganha evidência. Todos os entrevistados mais novos mencionaram as condições da personagem em dificuldade ao justificarem a opção por ajudá-la: "Porque a Rafaela não sabia bem matemática” (Patrícia, 6; 11); “(...) ele estava com dificuldade” (Rodrigo, 6; 8). Mas, aqui, conforme podemos observar nos exemplos, não há uma atribuição de responsabilidade a essa personagem pela situação em que se encontrava e/ ou pela resolução do próprio problema, mas uma certa sensibilidade para com o estado alheio. Vimos anteriormente que, em todas as nossas pesquisas sobre generosidade (Vale, 2006; Vale \& Alencar, 2008a, Vale \& Alencar, 2008b; Vale \& Alencar, 2009; Vale \& Alencar, no prelo), as condições de quem precisava de ajuda aparecem nas justificativas dos participantes que decidem pela virtude. Vimos também que esse tipo de argumentação nos remete ao sentimento de simpatia, já que tais entrevistados demonstram uma comoção com o sofrimento do outro. Considerando que todos os participantes de 6 anos que fizeram a opção por ajudar o colega recorrem a essa justificativa, nossos dados comprovam que a simpatia é mesmo uma forte motivação para as respostas de generosidade das crianças pequenas.

Ainda nessa categoria, há a justificativa de uma única entrevistada de 12 anos que merece destaque:

$E$, porque, quando a gente entrega o trabalho depois, a gente perde dois pontos, aí, o trabalho fica valendo 8,0. Aí, ela tenta fazer um trabalho ótimo para conseguir nota 8,0 e ajudar a amiga dela. Porque ela poderia entregar o trabalho depois, porque ela poderia conseguir tirar 8,0, e 8,0 não é uma nota ruim. Mas, se a amiga dela não tirasse uma nota boa na prova do dia seguinte, a amiga dela não conseguiria ter nota no final do trimestre (Carla, 12; 6). 
Vejam que Carla, ao optar pela ajuda ao outro, apresenta o mesmo tipo de justificativa de Daniel $^{9}$, que se recusa a ajudar o colega. Como Daniel, Carla também estabelece uma comparação entre as circunstâncias relativas a cada personagem, mas, ao avaliar as implicações das opções disponíveis, chega à conclusão de que ajudar a colega, e portando deixar de fazer o próprio trabalho, é a melhor forma de reduzir os danos que estavam em jogo para ambas as personagens. É à justiça que Carla recorre para sustentar sua opção por ajudar o outro. Dois participantes tomam, portanto, decisões distintas acerca de um mesmo dilema moral, porém a estrutura e a coerência dos critérios que os levam a tais decisões são as mesmas. Ambos os juízos estão vinculados a uma noção geral de justiça.

A maioria dos participantes que decidiu ajudar o colega em dificuldade $(66,7 \%)$ mencionou a amizade como justificativa: "A amizade em primeiro lugar. Complicado você decidir entre a amizade ou você só se dar bem no trabalho, mas eu escolheria ajudar, a amizade” (Leonardo, 12; 8). Se a amizade é utilizada como critério de decisão para tais entrevistados, poderíamos supor que, não havendo o referido relacionamento, tal decisão não seria mantida? Foi o que pudemos verificar quando investigamos a influência do tipo de vínculo (amizade ou inimizade) entre duas pessoas ou da sua ausência (desconhecido) nos juízos referentes à possibilidade de manifestação da generosidade (Vale, 2006; Vale \& Alencar, 2008b). A maioria dos participantes decidiu pela ação generosa quando as personagens da história contada foram apresentadas como amigas e quando as mesmas foram tomadas como desconhecidas. A intensidade dessa ação, contudo, variou: um amigo, na opinião da grande maioria, deve receber mais lanche do que um desconhecido. Na situação de inimizade, nem mesmo uma ação generosa com intensidade mínima prevaleceu entre as respostas dos entrevistados, já que a maior parte deles decidiu pela ausência da virtude. Apenas $10 \%$ dos participantes não alteraram suas respostas em função do tipo de vínculo ou da sua ausência entre as personagens.

Posto isso, façamos a pergunta: podemos considerar moral uma decisão pela ação generosa justificada pelo sentimento de amizade? É a virtude generosidade que está em jogo nesses juízos tomados na dependência de um sentimento pessoal? Como bem disse Comte-Sponville (1995/1997), “(...) a generosidade nos convida, na falta de amor, a dar exatamente aos que não amamos por necessitarem mais ou por estarmos mais bem situados para ajudá-los" (p. 110). Ora, não parece ser este o caso desses participantes.

\footnotetext{
${ }^{9}$ Nome fictício de um dos participantes de 12 anos que optou por não ajudar o outro e também apresentou uma justificativa incluída na categoria circunstâncias atenuantes (Tabela 1). Sua argumentação foi utilizada como exemplo anteriormente.
} 
Por outro lado, não há como negar a íntima relação desse vínculo com o ato de ajudar a outrem. Garcia (2005), ao realizar uma revisão crítica da literatura (de 1995 a 2003) sobre os aspectos psicológicos da amizade na infância, constatou que o comportamento pró-social, que nos remete em parte à generosidade, “(...) tem sido um dos aspectos mais claramente associados à amizade" (p. 287). Pinheiro (2009), ao apresentar um conflito moral envolvendo a generosidade a jovens de 15 a 18 anos, verificou que a maioria manifesta a virtude integrada à amizade. Garcia \& Pereira (2008), ao entrevistarem crianças de 7 a 10 anos sobre diferentes aspectos desse vínculo, averiguaram que a maior parte reconhece a ajuda de amigos, principalmente nas atividades escolares, tema de nossa história. E essa ajuda, segundo os autores, está entre os motivos apontados pelas crianças ao falarem da importância de ter amigos.

A decisão por ajudar o outro de alguns participantes é também apoiada na possibilidade de fazer uma nova amizade ou fortalecer o vínculo já existente: “(...) para tentar uma nova amizade" (Ronaldo, 12; 3); “isso favorece a amizade” (Joaquim, 12; 2). Godbout (1992) define a dádiva como qualquer prestação de bem ou serviço com o objetivo de criar, alimentar ou restabelecer laços sociais. Gilligan (1982) também fala da ética do cuidado, que nos remete à generosidade, como uma busca por manter e enriquecer os relacionamentos entre as pessoas.

Cabe ainda uma última pergunta sobre a categoria amizade: Porque a maioria dos participantes que optou por ajudar o outro fez uso dessa justificativa se as personagens do dilema não foram apresentadas como amigas? É possível que o contexto da história tenha exercido influência sobre esse aspecto. Garcia \& Pereira (2008) ressaltam que, nas entrevistas que fizeram com crianças de 7 a 10 anos, a escola foi considerada a principal fonte de amizades e também o mais importante ponto de encontro dos amigos. Considerando que a instituição está em foco em nossa história, é plausível que nossos participantes tenham sido indiretamente induzidos a estabelecer tal vínculo entre as personagens. Vale destacar, todavia, que, quando a amizade era mencionada durante a entrevista, tomávamos o cuidado de ressaltar que a história não trazia informação a esse respeito e, dessa forma, as personagens não deveriam ser tomadas como amigas. Mesmo assim, os entrevistados insistiam que o conteúdo do dilema nos levava a considerar a existência de uma amizade entre as personagens: "Mas pode ser amigo porque vai um na casa do outro” (Ronaldo, 12; 3).

É mesmo possível que a história contada ofereça aspectos de uma relação de amizade, mas, como veremos adiante, essa categoria aparece como justificativa nas decisões referentes a outras histórias de nossa pesquisa, que trazem elementos diversos dos aqui apresentados. Perguntemo-nos então: O conteúdo de todas as histórias nos induz, de fato, a tomar as 
personagens como amigas ou o critério de amizade desses participantes tem sido raso e superficial? A definição de amizade apresentada por Leonardo $(12 ; 8)$ nos permite apostar na segunda alternativa: "É, mas, no meu caso, qualquer pessoa que eu conheça, que eu tenha um bom contato ou mesmo que seja do meu prédio e eu só encontre às vezes no elevador...” (Leonardo, 12; 8).

As reflexões de La Taille (2009) sobre os rumos sociais da contemporaneidade nos ajudam a pensar a questão. $\mathrm{O}$ autor fala sobre a fragmentação do mundo atual, onde o presente se torna fragmento de tempo e, privado de solidez, não estabelece ligação entre o passado e o futuro. A mesma fragmentação também ocorre com o espaço, com o conhecimento e a informação, com as atividades e as relações humanas. Segundo La Taille:

(...) o homem contemporâneo caminha sem visibilidade em uma espessa bruma, caminha sem reais projetos, sem real memória, sem hierarquia clara de valores ou com valores efêmeros, emprestando aqui e ali identidades descartáveis que se sucedem e se sobrepõem umas às outras. Se tal quadro corresponde, nem que seja de forma aproximada, à realidade de nossos dias, não é de se estranhar que as relações interindividuais tenham características semelhantes. Afinal por qual milagre elas escapariam à deliquescência do ambiente? (p. 51).

A generalização do conceito de amigo é um dos indícios, segundo La Taille (2009), de que as relações sociais contemporâneas não escapam dessa sina. $\mathrm{O}$ autor lembra aqui do discurso da psicóloga Rosely Sayão, em uma mesa-redonda, sobre a confusão que as pessoas têm feito entre ter amigos e ter colegas. Para a psicóloga, nos dias de hoje, os conhecidos são chamados de amigos, com quem se mantém relações superficiais, não privilegiadas, não criteriosamente escolhidas e instáveis. Aquele com quem me encontro casualmente no elevador pode ser meu amigo, como bem disse nosso participante Leonardo. Nas palavras de La Taille:

Não se sabe mais o que é a amizade, talvez porque ela esteja se tornando ave rara. A moda está mais para as reuniões povoadas de gente, para os grandes espaços nos quais se acumula uma massa de pessoas (...), está mais para o "ficar", ou o "pegar", como vêm dizendo adolescentes, do que para o "permanecer" (p. 64).

As observações de La Taille (2009) sobre o andar errático de nossa sociedade nos levam a considerar plausível, portanto, que o critério de amizade de alguns participantes seja mesmo raso e superficial. Não pretendemos, todavia, fechar a questão. Investigar esse tipo de vínculo não faz parte de nossos objetivos nem temos em mãos dados suficientes para explicar o aparecimento dessa justificativa em situações onde as personagens não são apresentadas como 
amigas. Mas, por outro lado, não podemos ficar inertes a esse dado e às reflexões que dele procedem. Fica aqui levantada a questão para pesquisadores que se dedicam a esse tema.

Voltando à Tabela 2, vemos que 33,3\% dos participantes que decidiram ajudar o colega em dificuldade mencionaram como justificativa a reciprocidade pragmática:

Existe até uma fábula que eu li sobre um passarinho e uma formiga, e a moral da história é "ajude para ser ajudado". Depois que a Tatiana ajudar a Rafaela, a Rafaela pode ajudá-la. Um dia, pode acontecer de ela estar com muitos problemas mesmo, e a Rafaela pode ajudá-la (Eda, 9; 3).

Essa categoria de justificativa nos remete ao estágio 2 do nível pré-convencional de Kohlberg (1992), já que há uma preocupação com a manutenção das relações de trocas concretas. Aqui, os participantes julgam correto ajudar o outro para que, em situações análogas, sejam ajudados também.

Por fim, na categoria outros, incluímos uma única justificativa, que não se enquadrou nas categorias citadas anteriormente nem apareceu com uma frequência suficiente para abrirmos uma nova categoria.

Continuemos averiguando que lugar a generosidade ocupa no universo moral infantil em contraposição à justiça (para consigo mesmo). Agora, porém, façamos uso de uma nova história com o mesmo conflito em jogo.

\subsubsection{História 2}

Na segunda história de nosso estudo, a ajuda ao outro pressupõe um prejuízo material: Deve a personagem em conflito entregar o MP3, que havia acabado de ganhar como prêmio de um campeonato, a um pobre menino que teve o mesmo aparelho roubado? Ou deve a personagem negar ajuda a esse menino e, assim, usufruir de seu merecido prêmio? Eis o segundo dilema apresentado aos nossos participantes.

Os resultados se invertem com a nova situação proposta: todos os participantes de 6 e 9 anos e $90 \%$ dos entrevistados de 12 anos decidiram ajudar a personagem assaltada. Conforme podemos observar na Figura 2, encontramos respostas de ajuda com prejuízo total, com prejuízo parcial e até mesmo isentas de prejuízo. Sabemos que o prejuízo pessoal é ilustrado nessa história pela renúncia a um aparelho de MP3. É a essa perda material que nos referimos 
quando apresentamos as categorias referentes às respostas de nossos participantes. É claro que um ato de ajuda pode acarretar diversos outros prejuízos, muitos, inclusive, imensuráveis, mas nos propomos analisar aqui o dano material que, na concepção de alguns entrevistados, se fez necessário para dar ao outro o que lhe faltava.

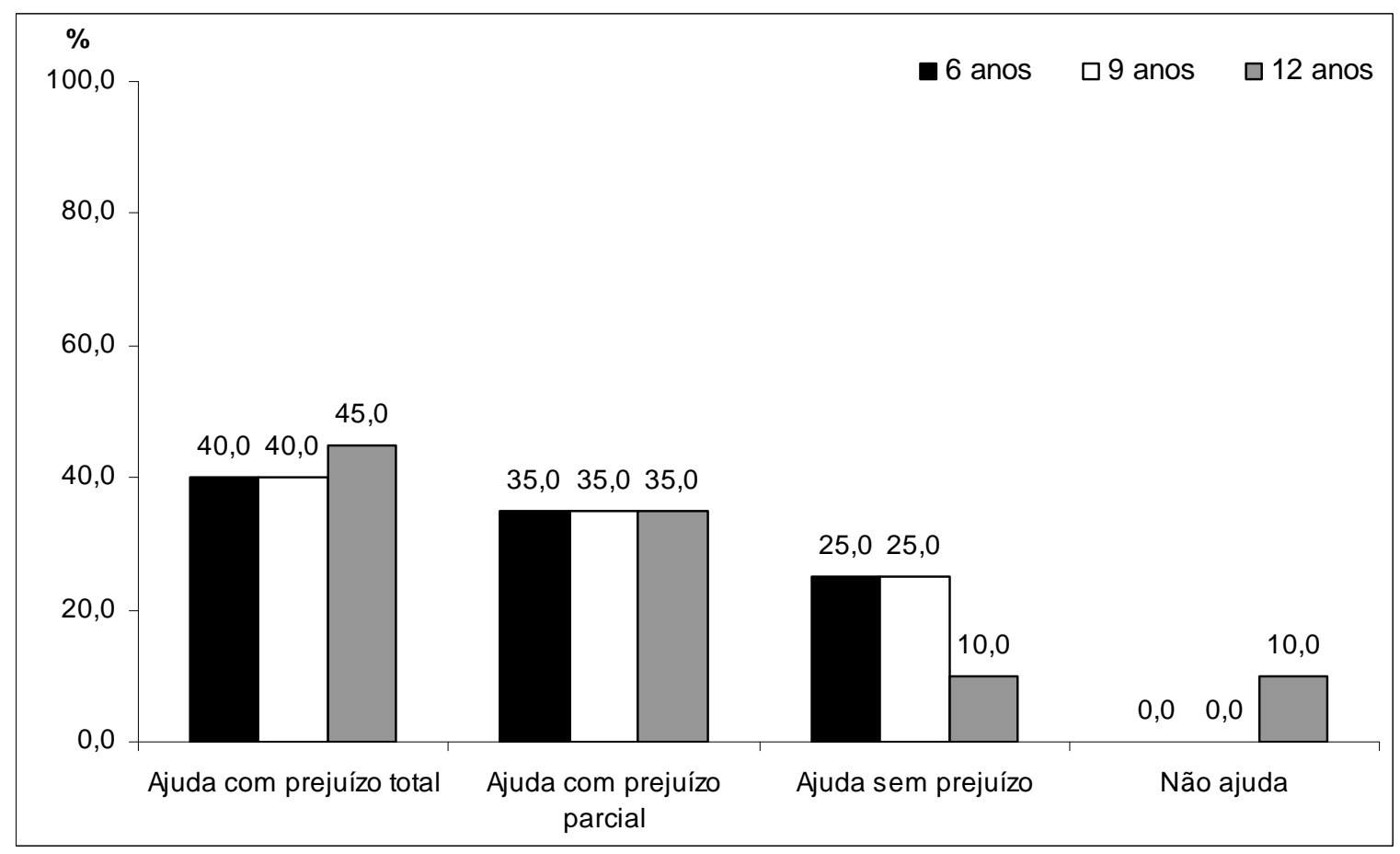

Figura 2. Generosidade em contraposição à justiça (para consigo mesmo) - história 2: comparação das respostas dos participantes conforme a idade.

A maior parte dos participantes de todas as idades $(41,7 \%)$ sugeriu a ajuda com prejuizo total como solução do dilema proposto. Incluímos nessa categoria as respostas que sugeriam que a personagem em conflito deveria entregar o próprio MP3 àquela que teve o mesmo aparelho roubado: "Eu acho que o Márcio pode, de caridade, dar o MP3 para ele" (Carlos, 9; 6). Vale ressaltar que $12 \%$ desses entrevistados tentaram, inicialmente, conciliar os dois elementos morais conflitantes, mas, diante de uma contra-argumentação, decidiram ajudar o outro: "Eu acho que a Márcia deveria convidá-la para competir no time dela para conseguir ganhar outro MP3.” Diante da impossibilidade: “Eu acho que ela deveria dar o MP3 para ela (...)” (Elisa, 12; 4). 
A ajuda com prejuizo parcial foi indicada por $35 \%$ dos participantes, que sugeriram um empréstimo do MP3 à personagem assaltada: “Deve emprestar para a Aline. Aí, faria assim: uma ficaria um pouco, e a outra ficaria outro pouco. Durante uma semana, seria meu e, durante uma semana, seria dela” (Lorena, 9; 11). O dano material é parcial, nesse caso, porque a personagem abdicaria de seu aparelho apenas durante determinados períodos, e não o tempo inteiro.

A maior parte dos participantes de 6 anos se restringiu a sugerir o empréstimo do MP3, já os entrevistados mais velhos da pesquisa, em sua maioria, estipularam, de antemão, o tempo que cada um teria para desfrutar do aparelho:

Eu pensei assim: eu ficaria dois meses com o MP3 e, depois desses dois meses, eu daria para ele ficar um mês. Depois, eu ficaria dois meses, ele ficaria um mês, dois meses, um mês, revezando assim. Como era meu, eu ficaria um mês a mais (João, 12; 1).

É importante destacar que 9,5\% desses entrevistados só decidiram pela ajuda com prejuízo parcial depois de tentarem conciliar as variáveis morais contrapostas: "Uma vaquinha com as amigas dela para comprar um MP3 novo para a Aline." Diante da impossibilidade: "Ela pode vender o MP3 dela, pegar um pouquinho de dinheiro da Aline, um pouquinho de dinheiro dela e comprar dois MP3's não tão bons quanto o primeiro”. Diante da impossibilidade: "Ela pode vender o MP3 novo dela para os pais da Aline por um preço melhor do que o da loja e pode comprar um novo. Ela pode pedir para a mãe um pouquinho de dinheiro." Diante da impossibilidade: “Aí, a Aline poderia usar o mesmo MP3, as duas dividiriam o mesmo MP3. O MP3 não seria nem só da Márcia nem só da Aline. Um dia ficaria com a Aline, outro dia ficaria com a Márcia” (Carla, 12; 6).

A ajuda sem prejuízo foi indicada por $20 \%$ dos participantes. A maior parte deles sugeriu ajudar a personagem roubada a recuperar o próprio MP3: “Ajudar. Procurando o ladrão que estava roubando o MP3. Usando uma lupa para ver qual pista ele deixou. Aí, elas vão atrás das pistas até encontrar o MP3" (Tereza, 6; 3). A maioria dos entrevistados das duas primeiras faixas etárias recorreram a uma autoridade (pais e/ ou polícia) na busca pelo aparelho roubado: “O Márcio poderia falar para os pais do amigo para os pais ligarem para alguma delegacia ou algum negócio autoritário para procurarem o ladrão que roubou o MP3” (Gabriel, 9; 10). Uma outra alternativa apresentada pelos participantes foi o consolo à personagem assaltada: "Eu acho que ela deve ajudá-la, consolá-la. Falar: 'Fica calma. Vai dar tudo certo'. Pelo menos, tinha uma pessoa para apoiar, ajudar, consolar” (Marina, 9; 8). 
Essa segunda alternativa aparece nas respostas de alguns participantes de 9 anos e em todas as respostas dos entrevistados mais velhos incluídas nessa categoria.

Lembramos, mais uma vez, que o prejuízo tratado aqui se refere a uma perda material. Nessa última categoria, incluímos, portanto, respostas que apontam para um tipo de ajuda que não pressupunha uma renúncia (total nem parcial) ao aparelho de MP3. Estamos certos de que há outros possíveis prejuízos em jogo, como, por exemplo, o tempo despendido no consolo ao outro ou na busca pelo MP3 roubado, todavia, não os abordaremos no contexto dessa análise.

Como podemos perceber na Figura 2, não há diferença considerável na distribuição das respostas de acordo com as idades pesquisadas. Mais uma vez, nossos dados parecem, em um primeiro momento, ir de encontro a nossa hipótese. Conforme supúnhamos, a decisão de ajudar a personagem assaltada e, portanto, a generosidade impera nas menores faixas etárias de nosso estudo, todavia, ao contrário do que conjeturamos, a mesma decisão também predomina na última faixa de idade pesquisada, não havendo, a princípio, uma gênese nos juízos infantis referentes à contraposição entre a generosidade e a justiça (para consigo mesmo). Mas não fechemos a questão sem antes analisarmos os critérios que levaram a grande maioria de nossos participantes a decidir pela ajuda ao outro (Tabela 3$)^{10}$.

Tabela 3

Generosidade em contraposição à justiça (para consigo mesmo) - história 2: distribuição conforme a idade das justificativas dos participantes que decidiram ajudar o outro

\begin{tabular}{|c|c|c|c|c|c|c|c|c|}
\hline \multirow{2}{*}{ Justificativa } & \multicolumn{2}{|c|}{6 anos } & \multicolumn{2}{|c|}{9 anos } & \multicolumn{2}{|c|}{12 anos } & \multicolumn{2}{|c|}{ Geral } \\
\hline & $\mathrm{N}^{\circ}$ & $\%$ & $\mathrm{~N}^{\circ}$ & $\%$ & $\mathrm{~N}^{\circ}$ & $\%$ & $\mathrm{~N}^{\circ}$ & $\%$ \\
\hline $\begin{array}{l}\text { Circunstâncias de quem precisava } \\
\text { de ajuda }\end{array}$ & 13 & 65,0 & 9 & 45,0 & 6 & 33,3 & 28 & 48,3 \\
\hline Comparação das circunstâncias & 0 & 0,0 & 4 & 20,0 & 7 & 38,9 & 11 & 19,0 \\
\hline $\begin{array}{l}\text { Circunstâncias de quem precisava } \\
\text { tomar a decisão }\end{array}$ & 1 & 5,0 & 2 & 10,0 & 1 & 5,5 & 4 & 6,9 \\
\hline Amizade & 8 & 40,0 & 5 & 25,0 & 5 & 27,8 & 18 & 31,0 \\
\hline Reciprocidade pragmática & 0 & 0,0 & 1 & 5,0 & 2 & 11,1 & 3 & 5,2 \\
\hline Outros & 1 & 5,0 & 3 & 15,0 & 1 & 5,5 & 5 & 8,6 \\
\hline
\end{tabular}
${ }^{10}$ Muitos participantes apresentaram mais de uma justificativa para suas respostas, por isso, na Tabela 3, como
nas tabelas anteriores, o número total de justificativas é superior a quantidade de entrevistados. 
Como na primeira história, as circunstâncias da situação apresentada aparecem com bastante frequência nas justificativas dos participantes: $74,1 \%$ daqueles que decidiram ajudar a personagem assaltada recorreram a essas circunstâncias para argumentarem suas decisões. Para melhor observarmos as semelhanças e diferenças entre as idades e, assim, facilitar a discussão dos resultados, optamos por distribuir essas justificativas em três categorias: circunstâncias de quem precisava de ajuda; circunstâncias de quem precisava tomar a decisão e comparação das circunstâncias (Tabela 3).

Quase a metade dos participantes que optaram por ajudar o outro $(48,3 \%)$ mencionou as circunstâncias de quem precisava de ajuda para justificar sua resposta. As circunstâncias trazidas à baila por esses entrevistados, na maioria das vezes, faziam parte do conteúdo da própria história: "Porque o garoto tinha acabado de ganhar o MP3, o ladrão roubou, e os pais dele não tinham dinheiro para comprar outro" (Fábio, 6; 4). De acordo com a Tabela 3, esta foi a justificativa mais utilizada por nossos entrevistados, o que mostra, mais uma vez, a íntima relação do sentimento de simpatia com o ato de ajudar a outrem e, portanto, com a virtude generosidade. $\mathrm{Na}$ argumentação de Eda $(9 ; 3)$, a comoção com o estado alheio aliada a uma moral da reciprocidade mostra como sua reflexão culminou na decisão pelo ato generoso: "Se eu perdesse alguma coisa que me deram no dia do meu aniversário, eu ficaria muito triste mesmo. Se uma amiga me ajudasse, seria bem legal, bem simpático da parte da amiga”.

Vejam que, embora a porcentagem relativa a essa categoria seja alta em todas as faixas etárias, a mesma prevalece na menor idade pesquisada e decresce nas idades seguintes (Tabela 3). Esse dado parece reforçar a hipótese de que é mesmo a simpatia que inspira as crianças pequenas a decidirem pela generosidade em detrimento da justiça (para consigo mesmo). Tal fato não quer dizer, vale frisar, que o mesmo sentimento não infunda a mesma decisão nos mais velhos, haja vista a alta porcentagem dessa categoria nas outras idades também. O que defendemos anteriormente é que, uma vez concebida a noção de justiça, esta também passará a regular as implicações e os limites da decisão por um ato de ajuda. É o que nos mostra os resultados referentes à categoria seguinte da Tabela 3: comparação das circunstâncias.

Nessa segunda categoria, os participantes não só mencionaram as condições de ambas as personagens como estabeleceram uma comparação entre elas para, então, efetuarem suas escolhas. A maior parte dos entrevistados mencionou a forma como o MP3 foi adquirido por cada personagem. Nas suas concepções, o MP3 comprado com o dinheiro do trabalho árduo 
dos pais de uma das personagens tem maior valor do que o aparelho conquistado pela outra como prêmio de um campeonato:

Os pais dela deveriam trabalhar muito, muito e muito. E perder esse MP3 foi uma perda que magoou tanto a Aline porque ela pediu, e os pais se esforçaram tanto, e a amiga dela ganhou de graça. E, aí, seria como se fosse um novo presente que compensaria o roubo e o esforço dos pais dela (Joana, 9; 7).

Alguns participantes atribuíram, ainda, maior valor à vitória no campeonato, e não ao prêmio resultante, amenizando assim o prejuízo em jogo:

Mesmo que o prêmio tenha um grande valor, o que importa no jogo é competir, se divertir. Eu acho que eu daria porque o dele foi mais valorizado do que o meu. (...) os pais trabalharam duro para poder comprar isso, tinham dificuldade financeira (Leonardo, 12; 8).

Encontramos também, entre essas justificativas, menções à felicidade de uma personagem com a vitória no campeonato contraposta à tristeza da outra com o roubo no dia de seu aniversário:

(...) já que o amigo ganhou o MP3 de aniversário, foi uma data especial, ele ganhou um presente e não vai ganhar outro. E o Márcio, não, foi só no jogo de futebol.... Pensando em tudo: no pai, na mãe, sendo aniversário e não campeonato... Ele já estava super feliz de ganhar o campeonato e tal. $O$ amigo, não: "perdi o meu aniversário e, ainda, о теи MP3” (Daniel, 12; 6).

Conforme vimos anteriormente, essas justificativas, nas suas mais variadas versões de equacionamento da situação, nos remetem à justiça distributiva, mais especificamente à equidade. É justo, na concepção desses entrevistados, dar a alguém que teve roubado o seu presente de aniversário, comprado com o árduo trabalho dos pais, aquilo que você ganhou como prêmio de um campeonato. Ao avaliarem e pesarem as condições singulares de cada personagem, esses participantes parecem agir mais com justiça do que com generosidade. É à justiça que eles recorrem para sustentar suas escolhas, mesmo que essas escolhas se refiram à abdicação de um bem material para ajudar a outrem. Considerando que essa categoria de justificativa prevalece na idade de 12 anos e inexiste na menor faixa etária pesquisada, nossa hipótese, mais uma vez, ganha força aqui.

As circunstâncias de quem precisava tomar a decisão aparecem em todas as idades, porém com porcentagens baixas, conforme pode ser observado na Tabela 3. Aqui, os participantes mencionaram a possibilidade da personagem em conflito adquirir um novo MP3 em uma outra oportunidade (em um próximo campeonato, no aniversário ou em uma compra com suas 
economias financeiras): “(...) porque ela poderia jogar queimada num outro dia, aí, ela poderia ganhar outro. Ou, se a Márcia trabalhasse, ela poderia ganhar um pouco de dinheiro e comprar outro para ela” (Patrícia, 6; 11).

$\mathrm{Na}$ história 2, as personagens também não foram apresentadas como amigas, mas a amizade constitui aqui uma das categorias de justificativa mais comum entre os entrevistados que decidiram ajudar o outro: "O importante é ajudar os amigos. Porque os amigos valem mais do que qualquer coisa” (Márcio, 12; 5).

A reciprocidade pragmática também aparece, com uma porcentagem baixa, nas justificativas dos participantes de 9 e 12 anos que decidiram ajudar a personagem assaltada da segunda história: “(...) pois, numa outra vez, quando o Márcio for roubado, o Antônio vai ajudá-lo” (João, 12; 1).

Entre as justificativas incluídas na categoria outros, destacamos aquelas que apontam para o prazer ou bem estar suscitado por um ato de generosidade: "Porque, aí, ela se sentiria bem. Ela iria sentir falta do MP3, mas ela se sentiria bem com a felicidade da amiga" (Nicole, 9; 7).

Os únicos participantes que decidiram não ajudar a personagem assaltada mencionaram a importância do prêmio para a personagem em conflito:

Porque é o prêmio dela. Tudo o que a gente ganha, a gente não tem que ficar dando para os outros. Presente não é para ser dado, presente é para você ganhar. Foi um prêmio importante para ela (...). E ela não tinha outro (Anita, 12; 4).

Conhecidos e discutidos os resultados referentes à segunda história, vamos às conclusões que pudemos chegar com este estudo.

\subsection{Conclusões}

No presente estudo, tivemos como objetivo averiguar, em um contexto psicogenético, que lugar a generosidade ocupa no universo moral infantil em contraposição à justiça (para consigo mesmo). Para tanto, fizemos uso de duas histórias-dilema onde a manifestação de generosidade para com o outro implica em um forte prejuízo pessoal, ou seja, em uma injustiça para consigo mesmo. Na primeira história, a ação generosa pressupõe um prejuízo escolar e, na segunda, uma perda material. Fizemos a hipótese de que a criança pequena, 
perante os elementos morais conflitantes, tenderia a decidir pela generosidade em detrimento da justiça (para consigo mesma). No decorrer do desenvolvimento, contudo, a justiça deveria prevalecer paulatinamente sobre a ação generosa, sendo, dessa forma, privilegiada pelos participantes mais velhos de nossa pesquisa.

Quando a generosidade para com o outro pressupõe um prejuízo escolar, as crianças mais novas de nosso estudo não privilegiam a virtude, mas, conforme conjeturamos, também não é a noção de justiça (para consigo mesma) que assume tal privilégio. Destacamos a subordinação à autoridade (implícita na primeira história) e o hedonismo, típicos do início do desenvolvimento moral infantil, nas justificativas que a maioria dos participantes mais novos apresentou para a decisão de recusar ajuda a outrem.

Quando a ação generosa implica em uma perda material, todos os entrevistados das duas primeiras faixas etárias pesquisadas optam pela virtude, dado que corrobora a nossa hipótese. Embora a amizade seja um critério de decisão muito utilizado pelos mais novos, é a simpatia que impera em suas justificativas, o que comprova que esse sentimento é mesmo uma forte motivação para os juízos das crianças pequenas voltados para a generosidade.

A grande maioria de nossos participantes mais velhos também toma decisões distintas acerca de um mesmo dilema ilustrado com conteúdos diversos. Na primeira história, a maior parte decide pela recusa de ajuda àquele em dificuldade. Na segunda, o resultado se inverte: quase todos optam por ajudar o outro. Todavia, em ambas as situações, a maioria das justificativas de suas escolhas nos remete à noção de justiça, conforme vislumbramos. É à justiça que esses participantes recorrem para sustentar suas decisões, mesmo que estas se refiram à abdicação de um bem material para ajudar a outrem. Nossos entrevistados mais velhos fazem, assim, escolhas distintas acerca de um mesmo conflito moral, porém a estrutura e a coerência dos critérios que os levam às suas decisões são as mesmas. Suas argumentações estão, em sua maioria, vinculadas a uma noção geral de justiça.

É importante ressaltar que, embora a maioria dos argumentos da maior faixa etária do estudo nos remeta à justiça, há outros critérios em jogo nos juízos dos mais velhos. A simpatia também inspira suas decisões de ajudar a outrem e até mesmo o sentimento de amizade foi muitas vezes utilizado como argumento por esses participantes. O que os resultados, de uma forma geral, nos mostram é que, uma vez concebida a noção de justiça, esta também passa a regular as implicações e os limites da decisão por um ato de ajuda.

No que diz respeito à nossa hipótese, se nos restringirmos às respostas apresentadas por nossos participantes, podemos descartá-la aqui. A maioria dos entrevistados de todas as idades pesquisadas decide recusar ajuda àquele em dificuldade na primeira situação e, na 
segunda, opta pela ajuda a outrem. Todavia, se nos atentarmos aos argumentos que os levaram a uma ou outra escolha, os resultados apresentados vão ao encontro de nossa hipótese. As justificativas dos mais novos nos remetem mais à generosidade, e os critérios utilizados pelos mais velhos estão atrelados à noção de justiça. Portanto, há sim uma gênese nos juízos dos participantes de diferentes idades acerca do conflito entre a generosidade e a justiça (para consigo mesmo). 


\section{ESTUDO 2: GENEROSIDADE E GRATIDÃO}

\subsection{Objetivos e hipóteses}

Vimos anteriormente que, quando somos generosos, damos ao outro o que corresponde a uma necessidade singular, e não o que lhe compete de direito. Da mesma forma, quem age generosamente não tem o direito de exigir gratidão daquele que recebe a benesse. A espontaneidade é característica da generosidade e da gratidão, e qualquer tentativa de exigibilidade exterior aniquilaria o valor de ambas as virtudes (La Taille, 2000). Se a gratidão ao ato generoso não corresponde a uma exigência social, tenderão as crianças a indicá-la como resposta a uma manifestação de generosidade? Que tipo de reação aquele que foi beneficiado com uma ação generosa deve ter na concepção das crianças? Eis as primeiras perguntas que inspiraram este estudo.

Um primeiro tipo de reação à generosidade que nos vem à cabeça é dizer um simples “obrigado". Embora essa palavra aponte para a gratidão, não é a esse valor que nos referimos aqui. Trata-se de uma expressão convencional nas relações sociais que nos remete à polidez, a mais pobre, superficial, ambígua e discutível das virtudes, segundo Comte-Sponville (1995/1997). "Virtude puramente formal, virtude de etiqueta, virtude de aparato! A aparência, pois, de uma virtude, e somente a aparência" (p. 13). A polidez não exige esforço e reflexão nem pressupõe sinceridade, todavia, é em geral uma qualidade apreciada que sinaliza atitudes de respeito moral pelo outro (La Taille, 2001a). "A polidez traduz certa deferência para com outrem, o reconhecimento de sua existência e valor" (La Taille, 2001a, p. 98). Além disso, Comte-Sponville considera essa "pequena virtude" como a origem de todas as outras. "As boas maneiras precedem as boas ações e levam a estas" (p. 16). Para o autor, "a polidez é essa aparência de virtude, de que as virtudes provêm" (p. 18). "E que criança se tornaria virtuosa sem essa aparência e essa amabilidade?" (p. 16), questiona o filósofo francês.

Com base nas afirmações de Comte-Sponville e nas teses de autores como Freud, Piaget e Kohlberg, La Taille (2001a) levanta a hipótese de que a polidez faz parte do universo moral da criança mais nova e cumpre uma função na gênese da moralidade. Para averiguar a pertinência de sua tese, o autor realizou uma pesquisa empírica com crianças de 6, 9 e 12 anos de idade. Os resultados encontrados mostram que, em todas as idades, a polidez é assimilada a um dever moral pela maioria dos participantes, mas com a peculiaridade de sua falta não 
merecer castigo. Os dados também mostram que a falta de polidez é, para as crianças de 6 anos, um indício para se julgar o caráter moral de alguém e deixa de sê-lo para as crianças de 12 anos, com uma fase de transição aos 9 anos. Por fim, foi verificado que a falta de polidez é vista como uma conduta de certa gravidade nas três faixas etárias estudadas. Os resultados dessa pesquisa nos levam a considerar plausível, portanto, que nossos participantes, inclusive os mais novos, indiquem, pelo menos, o simples agradecimento como reação a um ato generoso.

Mas sejamos otimistas e pensemos na possibilidade de nossas crianças considerarem que uma manifestação de generosidade pede mais do que o simples emprego de fórmulas verbais, pede retribuição, pede gratidão.

Embora haja um crescente interesse de pesquisadores pelo tema da gratidão, ainda há poucos estudos sobre a virtude na infância. Em uma busca no banco de dados PsycInfo, Freitas et al. (2009a, 2009b) encontraram, no período compreendido entre 2000 e 2007, apenas uma pesquisa realizada com crianças. A mesma busca foi realizada nos bancos de dados Scielo e Biblioteca Virtual de Saúde em Psicologia (BVS-PSI), e nenhuma referência sobre o desenvolvimento da gratidão foi localizada. A escassez de estudos na área foi um dos fatores que levaram as autoras, juntamente com outros pesquisadores, a desenvolverem trabalhos sobre a virtude na infância, que serão de grande valia para pensarmos em nossas hipóteses.

Castro et al. (2011) realizaram uma pesquisa sobre a gratidão com crianças de três grupos etários (5-6, 7-8 e 11-12 anos). A partir de uma situação hipotética na qual um adulto presta um favor a uma criança, as autoras perguntaram aos participantes se a criança beneficiada deveria retribuir a generosidade recebida. A maioria dos entrevistados de todas as idades respondeu à questão de forma afirmativa. Mileski (2010) realizou uma pesquisa sobre a ingratidão com crianças das mesmas faixas etárias, que foram solicitadas a julgar situações hipotéticas nas quais uma criança não retribui um ato generoso de outra criança quando surge a oportunidade de fazê-lo. A grande maioria dos participantes de todas as idades reprovou a conduta da personagem ingrata. O trabalho de La Taille et al. (1998) sobre as virtudes morais segundo as crianças atesta que a gratidão, assim como a generosidade, já faz parte do universo moral infantil.

As pesquisas comentadas aqui nos permitem, portanto, permanecer otimistas: nossas crianças poderão sim sugerir mais do que um simples "obrigado" como reação a uma manifestação de generosidade. Se, em todas as faixas etárias pesquisadas, a gratidão é indicada e sua falta, reprovada, podemos fazer a hipótese de que nossas crianças, inclusive as 
mais novas, tenderão a mencionar algum tipo de retribuição como resposta a um ato generoso. Mas ainda cabe uma outra pergunta: a gratidão já se encontra na sua forma mais evoluída desde a mais tenra infância ou podemos admitir uma gênese dessa virtude na criança?

La Taille et al. (1998) verificou que existe uma maior compreensão da palavra gratidão conforme as crianças ficam mais velhas. Castro et al. (2011), na pesquisa relatada acima, constataram uma evolução na forma como os participantes de diferentes idades justificaram a decisão pela gratidão. As crianças mais novas desse estudo se ativeram às consequências (materiais ou psicológicas) que a não retribuição traria à personagem generosa. A preocupação com um juízo alheio negativo predominou na faixa etária intermediária pesquisada, e a retribuição como um bem moral apareceu apenas na última faixa de idade do estudo. Mileski (2010) também encontrou diferenças significativas entre os grupos etários no que diz respeito às razões que levaram os entrevistados a reprovarem a ingratidão para com aquele que lhe foi generoso. As crianças mais novas justificaram suas avaliações com base na ação imediata da personagem ingrata e nas suas consequências para a personagem generosa. Já os participantes mais velhos mencionaram o princípio da reciprocidade ao avaliarem a conduta da personagem que não retribuiu à generosidade recebida.

De posse desses dados, podemos afirmar que a gratidão é valorizada pela criança pequena. Tal afirmativa, contudo, não nos leva a considerar que sua compreensão dessa virtude já seja plenamente autônoma. As pesquisas de La Taille et al. (1998), Mileski (2010) e Castro et al. (2011) nos mostram que a concepção de gratidão da criança passa sim por mudanças evolutivas. E o que podemos dizer sobre as diferentes formas de manifestação dessa virtude? Estas também sofrerão variações nas diferentes faixas etárias pesquisadas? Fazemos a hipótese de que o retorno material ou a recompensa com uma ação concreta prevalecerá nos juízos das crianças mais novas que indicarem a retribuição como resposta ao ato generoso. E a demonstração verbal do reconhecimento de uma dívida para com o outro deverá comparecer apenas nos juízos dos entrevistados mais velhos. Conheçamos as razões que nos levam a tal proposição.

Um primeiro argumento a favor da hipótese levantada diz respeito ao desenvolvimento cognitivo da criança. Seguindo a perspectiva piagetiana, por volta dos 7-8 anos de idade, a criança, com uma estruturação cognitiva operatório-concreta, enfoca, basicamente, aspectos concretos da realidade para refletir. A construção da lógica permite uma nova forma de organização do plano da representação. De acordo com Souza (2007), conforme o sistema de pensamento infantil se torna mais amplo e complexo, mais a criança se torna capaz de incluir em seus juízos elementos abstratos, e não somente aspectos materiais da realidade. Como 
poderiam, então, as crianças pequenas, provavelmente ainda em um período anterior ao pensamento operatório-concreto, indicarem como reação a um ato generoso a demonstração verbal de reconhecimento do lhe foi feito por outrem? Ora, considerando a incipiência de suas ferramentas intelectuais, parece-nos pouco provável, já que essa forma de manifestação da virtude nada tem de material ou concreto. Acrescentemos algumas pesquisas que vão ao encontro de nossa hipótese.

Souza $(2005,2007)$ investigou, à luz da teoria piagetiana, as relações entre os interesses, as valorizações afetivas e as virtudes relacionadas às qualidades admiráveis e não-admiráveis de personagens de diversos contos de fada. As entrevistas realizadas ilustram diferentes qualidades nas argumentações das crianças relacionadas aos aspectos (materiais ou abstratos) escolhidos como interessantes ou admiráveis. Segundo a autora, as crianças mais novas tendem a escolher elementos concretos como mais interessantes, enquanto as crianças mais velhas tendem a demonstrar interesses relacionados à reciprocidade e às virtudes. Enquanto os bens materiais das personagens chamam mais a atenção das crianças mais novas, aspectos ligados às relações e ao caráter das personagens são mais valorizados pelas crianças mais velhas.

Pieta (2009) realizou um estudo transversal com escolares de 7 a 14 anos para investigar as diferentes formas de manifestação da gratidão ao longo do desenvolvimento. Inspirada por uma pesquisa suíça (Baumgarten-Tramer, 1938), a autora perguntou aos participantes o que fariam eles para a pessoa que lhes desse o que mais querem. Ao analisar as respostas dos entrevistados, a autora encontrou os mesmos tipos de gratidão apresentados pela pesquisadora suíça, a saber: verbal, concreta, conectiva e finalística. A gratidão verbal diz respeito ao simples “obrigado", que nos remete à polidez, conforme comentado anteriormente. A gratidão é considerada concreta quando a criança oferece algo em troca de um favor recebido. A gratidão conectiva visa estabelecer uma relação espiritual com aquele que lhe foi generoso, e a finalística busca promover o próprio desenvolvimento pessoal. A autora verificou que a forma de se manifestar a gratidão varia de acordo com a idade. A gratidão concreta prevalece nas respostas das crianças mais novas, e a gratidão conectiva aumenta com o avanço da idade. A gratidão verbal, por sua vez, apareceu em todas as idades pesquisadas, muitas vezes, associada a um outro tipo de gratidão.

Os resultados dessas pesquisas reforçam a plausibilidade de nossa hipótese, mas conheçamos ainda um segundo argumento que também nos ajuda a sustentá-la.

A manifestação da gratidão na forma de uma demonstração verbal de reconhecimento àquele que lhe foi generoso pressupõe uma avaliação de suas intenções. Mas já vimos, com 
Piaget (1932/1994), que a criança pequena utiliza a responsabilidade objetiva como critério de avaliação de um ato, ou seja, dá mais importância às consequências de uma determinada ação do que à intenção do autor da mesma. Só mais tarde a responsabilidade subjetiva, ou seja, a intencionalidade passa a ser um critério necessário para a criança julgar moralmente uma dada situação. A partir dessa consideração, parece-nos pouco provável que a criança pequena demonstre verbalmente reconhecer seu débito para com aquele que agiu generosamente. Aliás, tal consideração nos leva inclusive a questionar se a retribuição concreta, que tende a ser indicada pela criança mais nova, representa de fato o reconhecimento de uma dívida para com outrem. Vimos que uma recompensa material pode ser uma autêntica expressão de gratidão, mas nem todo retorno concreto do favor recebido nos remete a essa virtude. Se a criança mais nova confere maior importância aos efeitos de um ato do que à intenção de seu autor, é provável que ela seja mais grata à ação generosa que lhe causou alegria do que àquele que, intencionalmente, manifestou a generosidade. Mas não poderíamos falar aí de gratidão? Vamos a uma outra pesquisa sobre a virtude para tentarmos responder à questão.

Para descrever o desenvolvimento da gratidão na infância, Freitas et al. (2009a, 2009b) tomaram como base o modelo que Bonnie e de Wall (2004) propuseram para explicar os processos psicológicos implicados nessa virtude. De acordo com esse modelo, o ciclo completo que conduz à gratidão propriamente dita pressupõe: uma apreciação da generosidade recebida, sentimentos positivos dirigidos àquele que the foi generoso, um reconhecimento dos custos da ação generosa e uma atribuição de intenção ao autor dessa ação. Segundo os autores, nem sempre o ciclo completo está presente na retribuição de um favor. Alguém pode, por exemplo, apreciar a generosidade que lhe foi dirigida e atribuir sentimentos positivos ao autor da ação generosa, mas não avaliar os custos dessa ação nem a intenção daquele que lhe prestou um favor. Nesse caso, de acordo com Bonnie e de Waal, a retribuição resultante consistiria em uma atitude positiva em relação ao generoso, mas não em uma valorização positiva de sua pessoa.

Partindo do modelo descrito, Freitas et al. (2009a, 2009b) realizaram uma pesquisa sobre a gratidão com crianças de três grupos etários (5-6, 7-8, 11-12 anos). A partir de situações hipotéticas nas quais uma personagem manifesta a generosidade para com outra, as pesquisadoras perguntaram aos participantes sobre os sentimentos que atribuíam à personagem beneficiada com uma ação generosa. Os resultados sugerem diferenças significativas entre os grupos etários estudados. As crianças de 5-6 anos indicaram sentimentos intra-individuais (feliz, alegre, bem), não estabelecendo, em sua maioria, relação alguma entre o sentimento positivo da personagem beneficiada com o ato generoso nem com 
o autor desse ato. Os participantes de 7-8 anos e, principalmente, os de 11-12 anos apresentaram sentimentos interindividuais (ajudado, agradecido, grato, apoiado) como resposta, relacionando tais sentimentos com a ação generosa e/ ou com quem manifestou a generosidade. Os dados dessa pesquisa vão ao encontro da constatação de Lourenço (2003) de que, antes dos 7-8 anos, as crianças tendem a levar em conta apenas o benefício recebido.

Freitas et al. (2009a, 2009b), a partir dos resultados encontrados, consideram que há um desenvolvimento da gratidão na infância. Segundo as autoras da pesquisa, o ciclo completo que conduz à gratidão propriamente dita, proposto por Bonnie e de Wall (2004), caracterizaria, especialmente, as respostas apresentadas pelas crianças de 11-12 anos. Antes disso, conjeturam as pesquisadoras, haveria um momento intermediário no qual as crianças valorizariam a ação generosa para, só depois, valorizar o próprio autor dessa ação.

A pesquisa apresentada corrobora, portanto, nossa hipótese. É possível que apenas os participantes mais velhos sugiram, como resposta a uma ação generosa, a demonstração verbal do reconhecimento de uma dívida para com o outro. O retorno material ou a recompensa com uma ação concreta deverá prevalecer nos juízos das crianças mais novas que indicarem a retribuição como reação ao ato generoso. O que os dados do estudo acima nos permitem acrescentar é a possibilidade da retribuição concreta, que deve ser sugerida pelas crianças pequenas, não nos remeter, necessariamente, à gratidão propriamente dita, mas a uma concepção mais elementar dessa virtude, indicando, dessa forma, um desenvolvimento da mesma ao longo da infância.

Ainda nos restam algumas perguntas sobre o tema da generosidade e gratidão. Fizemos a hipótese de que a retribuição a uma ação generosa e até mesmo a gratidão, mesmo que de forma incipiente, deverá ser valorizada por nossos participantes, inclusive os mais novos. Mas valorizar a gratidão implica considerá-la obrigatória? Vimos anteriormente que a criança pequena já diferencia ações inspiradas pela generosidade de ações inspiradas pela obediência a uma regra justa, alegando, inclusive, que a sanção deve ser aplicada apenas sobre aqueles que cometem um ato de injustiça (La Taille et al., 1998; Vale, 2006; Vale \& Alencar, 2008b). Se a criança já é capaz de entender que aquele que manifesta a generosidade não tem o dever de assim agir, compreenderá também que o mesmo não tem o direito de receber retribuição pelo o que fez? Compreenderá a criança que a gratidão a um ato generoso não coincide com a exigibilidade exterior? Precisamos ir a campo encontrar essas respostas. Se a criança pequena apresentar uma compreensão clara de que a ação generosa não pressupõe, necessariamente, algum tipo de retribuição, sua concepção sobre a virtude é ainda mais rica do que supúnhamos até então. Se ela entender a retribuição à generosidade como um dever derivado de um direito 
alheio, poderemos considerar a precocidade da generosidade no universo moral infantil, porém, com algumas lacunas, que poderão ser preenchidas progressivamente durante o desenvolvimento.

Finalizamos nossas inquietações relativas à generosidade com uma última pergunta: Para a criança, uma decisão sobre a manifestação de generosidade para com o outro deverá ser influenciada pela possibilidade de retribuição? Ou a probabilidade de um ressarcimento, de uma forma ou de outra, não deverá interferir em seu juízo? Se, na concepção da criança, a manifestação de generosidade pressupõe necessariamente algum tipo de retribuição, parecenos válido responder à primeira pergunta de forma afirmativa. Todavia, é possível que, mesmo ciente de que a retribuição à generosidade não está atrelada a uma exigibilidade exterior, sua decisão dependa, pelo menos em parte, da possibilidade de retribuição. Ora, sabemos que a retribuição, que pode ou não nos remeter à gratidão, pode ser admirada e até mesmo esperada quando se age generosamente, mas não pode ser esta a razão que leve alguém a assim agir. Este não é um argumento válido em juízos plenamente autônomos relativos à generosidade.

A partir das perguntas apresentadas ao longo de nosso texto, conheçamos, por fim, os objetivos deste estudo. Em um contexto psicogenético, pretendemos:

1. Pesquisar os juízos dos participantes referentes à reação que uma pessoa beneficiada com um ato de generosidade deve ter para com aquele que lhe foi generoso;

2. Verificar se, para os participantes, uma pessoa beneficiada com um ato de generosidade deve retribuir (ou agradecer) àquele que lhe foi generoso. Em caso de resposta afirmativa, identificar que tipo de retribuição ${ }^{11}$ (ou agradecimento) os participantes indicam àquele que manifestou a generosidade para com o outro;

3. Averiguar se a generosidade é compreendida pelos participantes na sua especificidade no que diz respeito à retribuição, verificando se, para os mesmos, a retribuição (ou o agradecimento) a uma ação generosa é obrigatória, ou seja, se corresponde a um dever derivado de um direito alheio;

4. Investigar a qual tipo de retribuição os participantes atribuem maior valor: à recompensa material ou à demonstração verbal do reconhecimento de uma dívida para com aquele que lhe foi generoso;

\footnotetext{
11 Vejam que, embora este estudo trate do tema da generosidade e gratidão, optamos por usar a palavra retribuição, e não gratidão, em nossos objetivos em virtude das nuances que existem entre os dois conceitos. Sabemos que a retribuição pode ser uma autêntica expressão de gratidão, mas que nem toda recompensa ao outro nos remete a essa virtude. Só uma análise cuidadosa das entrevistas realizadas nos permitirá dizer quando há, de fato, manifestação da gratidão em uma retribuição a outrem.
} 
5. Verificar se os participantes, ao julgarem se uma pessoa deve ou não ser generosa para com outra, são influenciados pela possibilidade de retribuição. Pesquisar, ainda, se a possibilidade de retribuição interfere nos juízos dos entrevistados a respeito da intensidade da ação generosa de uma pessoa para com outra.

\subsection{Método}

\subsubsection{Participantes}

Realizamos o segundo estudo com os mesmos participantes do estudo anterior: 60 alunos de uma escola particular da cidade do Rio de Janeiro - RJ, com 6, 9 e 12 anos, igualmente divididos quanto ao sexo e à idade.

\subsubsection{Instrumentos e procedimentos}

Realizamos os mesmos procedimentos mencionados no estudo 1, com atenção a todos os cuidados éticos previstos pelo CEPH do IPUSP.

As histórias utilizadas aqui abordam o tema da generosidade e gratidão. Na primeira história, coube a cada participante responder ao que uma pessoa, diante de uma situação de generosidade, deve fazer àquele que lhe foi generoso e se a mesma deve lhe retribuir (ou agradecer) a benesse. Fizemos uso da mesma história para investigar se, para os participantes, a retribuição (ou o agradecimento) à generosidade é obrigatória. Na segunda história, duas personagens beneficiadas por uma manifestação de generosidade apresentam dois tipos de retribuição à personagem generosa: a recompensa material e a demonstração verbal de reconhecimento do que lhe foi feito por outrem. A terceira e última história traz uma situação escolar cotidiana em que a generosidade pode ser manifestada para com duas pessoas. Uma delas costuma retribuir às ações generosas que recebe, e a outra, não. Eis as histórias seguidas das questões de investigação: 


\section{História 1}

Em um domingo de sol, os pais de Fernando o convidaram para ir à praia. Fernando adorava nadar e ficou muito feliz com o convite. Quando Fernando estava saindo de casa, seu vizinho, João, o chamou para brincar. Ele estava com a perna engessada e, por isso, não podia ir à praia. João não tinha ninguém para brincar com ele naquele dia e parecia triste. Fernando resolveu, então, deixar de ir à praia para fazer companhia para João.

a) O que você acha que o João deve fazer? Por quê?

b) Você acha que o João deve retribuir (ou agradecer) ${ }^{12}$ ao Fernando? Por quê?

Em caso de resposta afirmativa:

c) De que forma o João deve retribuir (ou agradecer) ao Fernando?

d) Você acha que o João tem obrigação de retribuir (ou agradecer) ao Fernando? Por quê?

Versão feminina: Fernanda e Maria

\section{História 2}

Paulo e Marcelo se inscreveram em um concurso de desenho da escola. No dia do concurso, eles receberam ajuda do Gustavo para fazer os desenhos. Os professores escolheram os três desenhos mais bonitos da escola. Paulo e Marcelo estavam entre os vencedores e foram premiados. Logo depois da premiação, Paulo procurou Gustavo para mostrar o seu prêmio. Disse a ele que conseguiu ganhar o concurso porque recebeu a sua ajuda e que nunca se esquecerá disso. Marcelo, depois da premiação, foi para casa brincar. No dia seguinte, Marcelo levou uma caixa de bombons para Gustavo como forma de retribuir a sua ajuda.

a) Você acha que o Paulo e o Marcelo agiram bem? Por quê?

b) Você acha que um deles agiu melhor?

Em caso de resposta afirmativa:

c) Quem agiu melhor? Por quê?

Versão feminina: Paula e Marcela; Gabriela

\footnotetext{
${ }^{12}$ Utilizamos os verbos retribuir e agradecer na mesma pergunta para evitar qualquer crença sugerida que o uso exclusivo de um dos dois verbos pudesse porventura provocar. A palavra retribuir poderia induzir a criança a apresentar algum tipo de recompensa como resposta, e o vocábulo agradecer poderia levá-la a indicar a polidez como reação à generosidade recebida.
} 
História 3:

Um dia, Vitor estava lanchando na hora do recreio e percebeu que Alexandre e Bruno estavam com fome. Vitor tinha um pacote com dez biscoitos, Alexandre e Bruno tinham nada para comer. Alexandre sempre gosta de retribuir os favores que fazem para ele. Bruno não costuma retribuir as ajudas que recebe e é até conhecido como "pão duro" na escola.

a) O que você acha que o Vitor deve fazer? Por quê?

b) Você acha que o Vitor deve dar biscoitos para o Alexandre? Por quê?

Em caso de resposta afirmativa:

c) Quantos biscoitos você acha que ele deve dar para o Alexandre? Por quê?

d) Você acha que o Vitor deve dar biscoitos para o Bruno? Por quê?

Em caso de resposta afirmativa:

e) Quantos biscoitos você acha que ele deve dar para o Bruno? Por quê?

Versão feminina: Vanessa, Alessandra e Bruna

\subsubsection{Tratamento dos dados}

No presente estudo, realizamos o mesmo tratamento dos dados do estudo 1, cujos passos descrevemos detalhadamente no capítulo anterior.

\subsection{Resultados e discussão}

\subsubsection{História 1}

$\mathrm{Na}$ primeira história de nosso estudo, uma criança decide abdicar de ir à praia em um domingo de sol para fazer companhia a um vizinho, que estava triste e com a perna engessada. Perguntamos inicialmente aos participantes sobre a reação que a personagem 
beneficiada deve ter para com aquele que lhe foi generoso. Apenas 16,7\% deles indicaram espontaneamente algum tipo de agradecimento e/ ou retribuição à personagem generosa. Quando fizemos a pergunta de forma direta, contudo, todos os participantes apresentaram uma resposta afirmativa, ou seja, julgaram que a personagem deve agradecer e/ ou retribuir àquele que lhe fez a benesse. Investigamos, então, que tipo de agradecimento e/ ou retribuição nossos entrevistados indicam para a situação apresentada. Vamos aos resultados encontrados $(\text { Tabela } 4)^{13}$.

Tabela 4

Tipos de reação à generosidade: distribuição das respostas dos participantes conforme a idade

\begin{tabular}{lcccccccc}
\hline \multirow{2}{*}{ Resposta } & \multicolumn{2}{c}{6 anos } & \multicolumn{2}{c}{9 anos } & \multicolumn{2}{c}{12 anos } & \multicolumn{2}{c}{ Geral } \\
\cline { 2 - 8 } & $\mathrm{N}^{\mathrm{o}}$ & $\%$ & $\mathrm{~N}^{\mathrm{o}}$ & $\%$ & $\mathrm{~N}^{\mathrm{o}}$ & $\%$ & $\mathrm{~N}^{\mathrm{o}}$ & $\%$ \\
\hline Polidez & 15 & 75,0 & 6 & 30,0 & 7 & 35,0 & 28 & 46,7 \\
$\begin{array}{l}\text { Demonstração verbal de } \\
\text { reconhecimento }\end{array}$ & 1 & 5,0 & 5 & 25,0 & 5 & 25,0 & 11 & 18,3 \\
Recompensa & 5 & 25,0 & 14 & 70,0 & 14 & 70,0 & 33 & 55,0 \\
\hline
\end{tabular}

Conforme conjeturamos, o emprego da fórmula verbal "obrigado", que nos remete à polidez, aparece em todas as faixas etárias pesquisadas: "Só para ser educada, ela poderia falar 'obrigada'” (Sabrina, 9; 6). Quase a metade de nossos participantes (46,7\%) recorreu à "pequena virtude" como resposta a uma ação generosa, com uma predominância dessa categoria na menor faixa de idade pesquisada (75\%). Acrescentamos a informação de que nessa faixa etária, o simples "obrigado" prima pela exclusividade enquanto que, nas demais idades estudadas, a fórmula verbal vem, na maioria das vezes, associada a algum tipo de retribuição. Mas por que a polidez ganha tamanha evidência entre as crianças mais novas?

A polidez é constituída por um conjunto de regras simples e precisas e, como mencionado anteriormente, seu emprego não exige esforço e reflexão nem pressupõe sinceridade. "Dito de outra maneira, o emprego das regras da boa educação pode muito bem contentar-se com uma interpretação ao 'pé da letra'” (La Taille, 2001a, p. 116), que nos remete ao realismo moral, característico da heteronomia (Piaget, 1932/1994). De acordo com La Taille, essas regras

\footnotetext{
${ }^{13}$ Vale ressaltar que $20 \%$ dos participantes apresentaram mais de uma opção de retribuição à ação generosa, por isso, na Tabela 4, o número total de respostas é superior à quantidade de entrevistados.
} 
mínimas de convívio, geralmente cobradas e impostas pelos adultos, são facilmente compreendidas e aplicadas pela criança pequena e ganham caráter plenamente moral no início do desenvolvimento. Os dados de sua pesquisa sobre o tema, já relatada acima, mostram que, para a criança mais nova, a boa educação não apenas sinaliza bons modos, mas também a índole moral de quem a emprega. Por isso, o autor afirma que a polidez ocupa um lugar relevante no despertar da gênese da moralidade infantil e, segundo Comte-Sponville (1995/1997), é a porta de entrada para as demais virtudes. É pela polidez que, “(...) imitando as maneiras da virtude, talvez tenhamos uma oportunidade de virmos a ser virtuosos" (p. 17). Sabemos que o emprego da fórmula verbal "obrigado" não indica que estamos profundamente gratos àquele que generosamente agiu. Mas, de acordo com Comte-Sponville, “(...) dizer 'obrigado' é simular reconhecimento. É aí que começam o respeito e o reconhecimento. Como a natureza imita a arte, assim a moral imita a polidez, que a imita" (p. 17). Ora, o reconhecimento do que nos foi feito por outrem nos remete à virtude gratidão, que fica evidente na segunda categoria da Tabela 4.

Apenas $18,3 \%$ dos participantes indicaram a demonstração verbal de reconhecimento como resposta à manifestação de generosidade: “Deveria falar assim: 'Obrigada por ter ficado aqui comigo hoje. Não havia mais ninguém para ficar comigo e, se você não viesse aqui, eu teria nada para fazer'” (Lia, 9; 3). É possível notar na fala sugerida por Lia um reconhecimento de que a generosidade do outro é a causa de um certo contentamento, de sua alegria. "A alegria do que é ou foi, contra a angústia do que poderia vir a ser" (ComteSponville, 1995/1997, p. 150). Vejam que o "obrigado" está presente no exemplo citado, mas, aqui, não se trata apenas do uso mecânico de um vocábulo convencional. Uma apreciação do que lhe foi feito por outrem e o reconhecimento espiritual de uma dívida para com o generoso, característicos da virtude gratidão, podem ser notados nas respostas incluídas nessa categoria: “Agradecer tipo assim: 'Cara, valeu! Muito obrigado, cara! Valeu por ter vindo me dar uma força aqui. Se você precisar de alguma coisa, é só ligar para mim," (Carlos, 9; 6).

Como pode ser observado na Tabela 4, a demonstração verbal de reconhecimento praticamente não aparece entre as crianças mais novas, o que mostra a pertinência de nossa hipótese. Na faixa etária intermediária de nosso estudo, essa categoria já aparece com $25 \%$ e assim permanece na idade mais avançada. Mas é a recompensa que ganha evidência nas duas 
últimas idades pesquisadas. A seguir, podemos averiguar suas variações nas respostas dos entrevistados (Tabela 5) ${ }^{14}$.

Tabela 5

Tipos de recompensa: distribuição conforme a idade das respostas dos participantes que indicaram a recompensa como reação à generosidade

\begin{tabular}{lcccccccc}
\hline \multirow{2}{*}{ Recompensa } & \multicolumn{2}{c}{6 anos } & \multicolumn{2}{c}{9 anos } & \multicolumn{2}{c}{12 anos } & \multicolumn{2}{c}{ Geral } \\
\cline { 2 - 9 } & $\mathrm{N}^{\mathbf{0}}$ & $\%$ & $\mathrm{~N}^{\circ}$ & $\%$ & $\mathrm{~N}^{\circ}$ & $\%$ & $\mathrm{~N}^{\circ}$ & $\%$ \\
\hline Programas e/ ou brincadeiras & 3 & 60,0 & 8 & 57,1 & 8 & 57,1 & 19 & 57,6 \\
Recompensa material & 2 & 40,0 & 0 & 0,0 & 0 & 0,0 & 2 & 6,1 \\
Recompensa recíproca & 0 & 0,0 & 7 & 50,0 & 6 & 42,8 & 13 & 39,4 \\
Amizade & 0 & 0,0 & 2 & 14,3 & 2 & 14,3 & 4 & 12,1 \\
\hline
\end{tabular}

Fizemos a hipótese de que a criança pequena indicaria, além da polidez, o retorno material ou a recompensa com uma ação concreta como reação à manifestação de generosidade. Vejam que são exatamente essas duas formas de retribuição que sugerem as crianças mais novas. Daquelas que indicaram a recompensa como resposta, $40 \%$ sugerem o retorno material: "Ele pode agradecer dando um presentinho, um bolinho de morango ou um brinquedo feito de papelão, todo pintado de águas correndo e pintado de amarelo com brilhantes para fingir que era uma praia” (Vitor, 6; 9). Uma das retribuições sugeridas por Vitor simboliza o programa do qual a personagem generosa precisou abdicar para manifestar a benesse. Parece haver aí um reconhecimento dos custos do ato generoso, que nos remete à gratidão. Talvez pela incipiência de suas ferramentas cognitivas, o entrevistado manifeste a virtude aqui por meio da oferta de um objeto concreto.

Uma outra sugestão apresentada por $60 \%$ das crianças de 6 anos que indicaram a recompensa como resposta foi o convite à personagem generosa para fazer programas e/ ou brincadeiras que fossem de seu agrado: "Com alguma brincadeira, algum jogo que a Fernanda gostasse muito, ou deixar a Fernanda ver um desenho que ela gostasse muito" (Sabrina, 9; 6). Aqui também comparecem referências ao reconhecimento dos custos da manifestação de generosidade, já que um dos programas mais citados por nossos participantes

\footnotetext{
${ }^{14}$ É importante saber que $15,1 \%$ dos participantes apresentaram mais de um tipo de recompensa, por isso o número total de respostas é superior à quantidade de entrevistados dessa categoria.
} 
foi a praia, exatamente aquele do qual a personagem generosa abrira mão. "Depois que ela melhorasse da perna, ela poderia juntar a família da Fernanda com a família dela e ir à praia. Aí, ela retribuiria aquele dia” (Anita, 12; 4).

Como pode ser observado na Tabela 5, essa categoria também prevalece nas idades de 9 e 12 anos, abrangendo quase $60 \%$ dos participantes que indicaram a recompensa como resposta. Nessas faixas etárias, porém, a recompensa material inexiste, e as formas de retribuição também caminham em direção a abstrações mais amplas. Vamos a elas.

A recompensa recíproca merece destaque nas faixas etárias de 9 e 12 anos:

Retribuir. Se o Fernando estiver na mesma situação, lembrar que ele já fez isso e poder ajudá-lo também.... No momento em que ele estava ruim, ele pôde contar com o Fernando, e o Fernando também tinha que ter certeza de que poderia contar com o João (Breno, 12; 5).

Há, nas respostas incluídas nessa categoria, o reconhecimento de uma dívida que poderá ser paga quando a personagem generosa se encontrar em circunstâncias semelhantes àquelas da personagem beneficiada. É dessa forma que a gratidão se faz presente aqui. "No outro domingo, no outro dia, se o Fernando chamar para brincar, ele, mesmo tendo alguma coisa para fazer, deve ajudar o amigo que também brincou com ele no dia que ele estava precisando" (Daniel, 12; 6). Se tais participantes sugerem que a personagem beneficiada trate o outro como gostou de ser tratada, é a moral da reciprocidade, característica da autonomia, que está implícita em suas falas. E, como pode ser observado na Tabela 5, só encontramos esse tipo de recompensa a partir dos 9 anos de idade, quando a criança começa a apresentar sinais da moral autônoma (Piaget, 1932/1994). Esse resultado vai ao encontro dos dados de Mileski (2010) sobre a ingratidão, já comentados anteriormente. Vimos que a maioria dos participantes mais velhos dessa pesquisa mencionou o princípio da reciprocidade para justificar a reprovação de uma atitude ingrata. Na pesquisa de Souza (2005, 2007), a reciprocidade nas relações de personagens de contos de fada também aparece como valor admirável e interessante para as crianças mais velhas.

Uma outra forma de recompensa que também nos remete a uma valorização mais abstrata é a amizade: "Ele deveria retribuir isso com uma amizade especial" (Breno, 12; 5). Pieta (2009), ao pesquisar as diferentes formas de manifestação da gratidão ao longo do desenvolvimento, verificou que a gratidão conectiva aumenta com a idade. Esse tipo de gratidão visa estabelecer uma relação com aquele que lhe foi generoso, podendo incluir aí a amizade que, aqui, aparece, embora de forma modesta, apenas nas duas últimas faixas etárias pesquisadas (Tabela 5). 
Conheçamos agora as razões que levaram nossos participantes a indicar o agradecimento e/ ou a retribuição como resposta a uma manifestação de generosidade (Tabela 6) ${ }^{15}$.

Tabela 6

Agradecimento el ou retribuição à generosidade: distribuição das justificativas dos participantes conforme a idade

\begin{tabular}{lcccccccc}
\hline \multirow{2}{*}{ Justificativa } & \multicolumn{2}{c}{6 anos } & \multicolumn{2}{c}{9 anos } & \multicolumn{2}{c}{12 anos } & \multicolumn{2}{c}{ Geral } \\
\cline { 2 - 8 } & $\mathrm{N}^{\mathbf{0}}$ & $\%$ & $\mathrm{~N}^{\mathrm{o}}$ & $\%$ & $\mathrm{~N}^{\mathbf{0}}$ & $\%$ & $\mathrm{~N}^{\mathrm{o}}$ & $\%$ \\
\hline $\begin{array}{l}\text { Generosidade } \\
\text { Generosidade associada àn } \\
\text { abdicação de um interesse próprio }\end{array}$ & 6 & 30,0 & 6 & 30,0 & 3 & 15,0 & 15 & 25,0 \\
Amizade & 0 & 0,0 & 0 & 0,0 & 5 & 25,0 & 5 & 8,3 \\
Reciprocidade pragmática & 1 & 5,0 & 1 & 5,0 & 2 & 10,0 & 4 & 6,7 \\
Outros & 0 & 0,0 & 1 & 5,0 & 0 & 0,0 & 1 & 1,7 \\
\hline
\end{tabular}

A grande maioria de nossos participantes $(93,3 \%)^{16}$ mencionou a generosidade como razão para a manifestação de um agradecimento e/ ou retribuição ao outro, o que demonstra uma clareza na compreensão do que estava em jogo na história contada: “(...) porque ele fez um favor, uma coisa legal. (...) Já que ele está fazendo uma coisa boa, o melhor que você pode fazer naquela hora é agradecer e, depois, retribuir" (César, 12; 9).

A maior parte dos entrevistados $(68,3 \%)$ não só citou a generosidade como também o sacrifício exigido pela manifestação da virtude na situação apresentada: "Porque ela sacrificou o direito de ir à praia com os pais para poder brincar com a amiga" (Maria, 12; 6). Sabemos que a generosidade, não raras vezes, exige privações voluntariamente impostas. Quando nossos participantes se referem à abdicação, por parte da personagem generosa, de satisfazer um interesse próprio, não só evidenciam uma compreensão clara da generosidade como conseguem articulá-la a uma outra virtude: a gratidão. Ser capaz de apreciar os custos de uma ação generosa, como vimos, é imprescindível no ciclo completo que conduz à gratidão propriamente dita, segundo o modelo de Bonnie e de Wall (2004). A ponderação dos

\footnotetext{
${ }^{15}$ Vale dizer que 8,3\% dos participantes apresentaram mais de uma justificativa para suas respostas, por isso o número total de justificativas é superior à quantidade de entrevistados.

${ }^{16}$ Esse resultado é relativo às duas primeiras categorias da Tabela 6, cujas justificativas fazem menção à virtude generosidade.
} 
custos da generosidade manifestada na história já estava implícita em algumas formas de retribuição sugeridas pelos entrevistados, mas aqui abarca a grande maioria das justificativas de todas as faixas etárias pesquisadas.

A amizade foi mencionada por $25 \%$ dos participantes mais velhos da pesquisa. Vimos que, no estudo 1, esta foi uma justificativa comum entre os entrevistados que decidiram pela generosidade, mesmo com a particularidade de que as personagens das histórias não tenham sido apresentadas como amigas. Aqui, também não há esse vínculo entre as personagens, mas o mesmo é pressuposto por alguns participantes em função da generosidade manifestada. E é o mesmo vínculo que os levam a indicar a retribuição como resposta:

E essa pessoa, se ela quer ter a minha companhia, é porque ela gosta de mim, ela quer ter uma boa amizade comigo. (...) Porque, se ele quis ajudar você, como eu já falei, é claro que ele quer ter uma boa amizade. Aí, é dar e receber (...). Ele retribui por uma questão de amizade mesmo (Leonardo, 12; 8).

Na pesquisa de La Taille et al. (1998) sobre as virtudes morais segundo as crianças, alguns participantes relacionaram a manifestação de gratidão com a criação e manutenção de laços de amizade. Na pesquisa de Mileski (2010) sobre a ingratidão, a amizade também foi um dos critérios utilizados por alguns entrevistados para a reprovação da conduta da personagem ingrata. Assim como a generosidade, a gratidão pode criar ou fortalecer vínculos (Freitas et al., 2009b), entre eles a amizade. Parafraseando Comte-Sponville (1995/1997): “A gratidão é nisso o segredo da amizade, não pelo sentimento de uma dívida, pois nada se deve aos amigos, mas por superabundância de alegria comum, de alegria recíproca, de alegria partilhada" (p. 152).

A reciprocidade, já implícita nas recompensas sugeridas por alguns entrevistados, também aparece como justificativa, mas é explicitada aqui de modo mais pragmático, com uma preocupação em manter as relações de trocas concretas: "Pelo fato de, eu adoro falar isso: dar e receber. É uma coisa tão importante como água para a gente” (Leonardo, 12; 8).

Vamos à última questão referente à primeira história de nosso estudo. Perguntamos aos nossos participantes se a personagem beneficiada com um ato generoso tem obrigação de agradecer e/ ou retribuir àquele que lhe fez a benesse. $\mathrm{O}$ resultado pode ser conferido na Figura 3. 


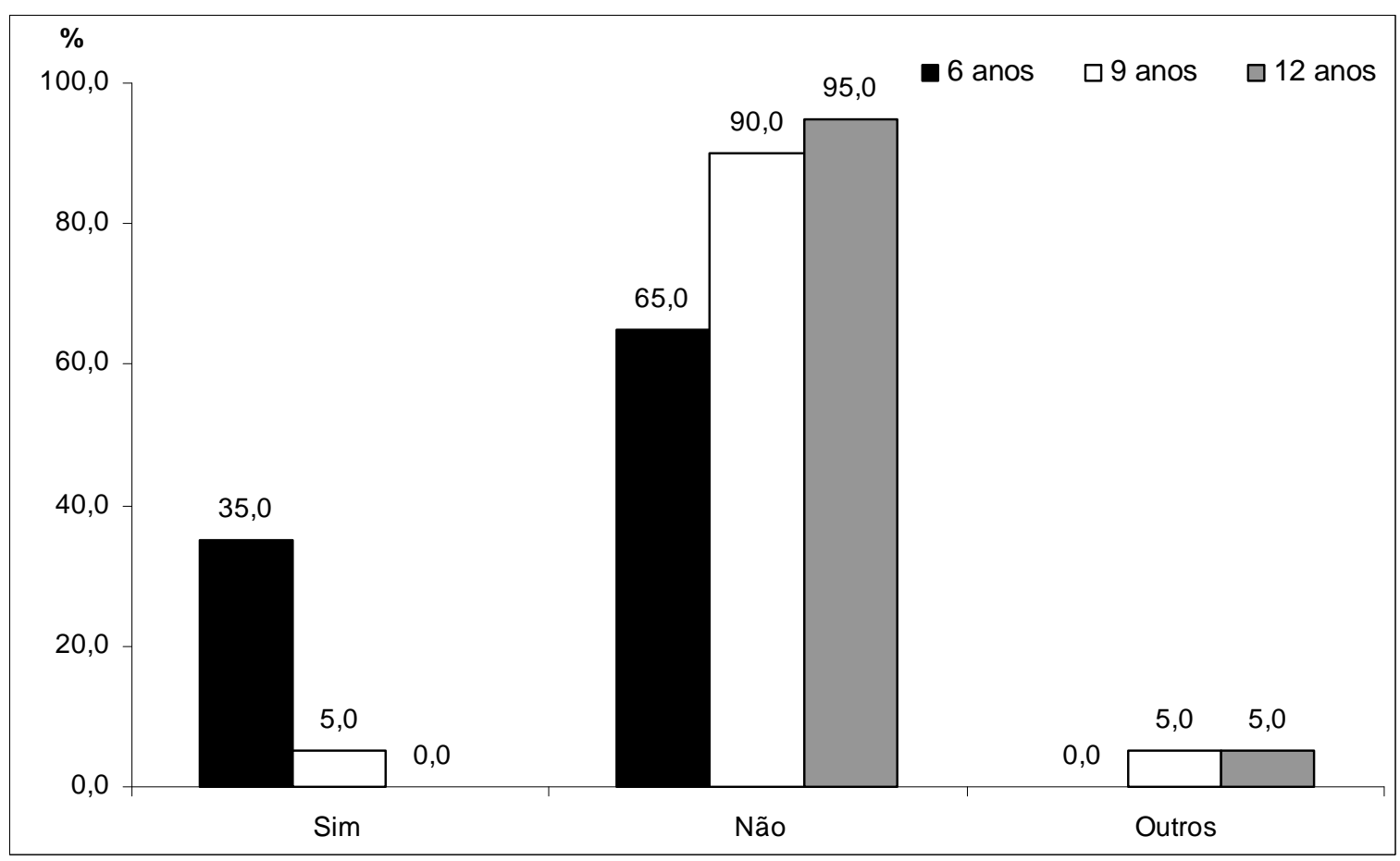

Figura 3. Obrigatoriedade do agradecimento e/ ou retribuição à generosidade: comparação das respostas dos participantes conforme a idade.

De acordo com a Figura 3, as porcentagens relativas a uma resposta negativa aumentam com a idade, o que aponta para um indício de gênese da questão. Vale ressaltar, todavia, que a não obrigatoriedade da retribuição (ou agradecimento) já predomina entre as crianças mais novas, abarcando $65 \%$ de suas respostas. Com o avanço da idade, esse número só tende a crescer, abrangendo a quase totalidade dos entrevistados da última faixa etária estudada.

Vimos que a generosidade, inspirada pela simpatia, ocupa um lugar diferenciado no universo moral infantil. Pesquisas mostram que a criança pequena já diferencia ações inspiradas pela generosidade de atos infundidos por uma regra justa (La Taille et al., 1998; Vale, 2006; Vale \& Alencar, 2008b). Pois nossos dados nos levam a afirmar que a criança mais nova não só entende que aquele que manifesta a generosidade não tem o dever de assim agir como também compreende que o mesmo não tem o direito de exigir agradecimento e/ ou retribuição de quem recebe a benesse. Sua concepção sobre a virtude, portanto, parece ser ainda mais rica do que supúnhamos até então. A primeira categoria de justificativa (Tabela 7) ${ }^{17}$ avigora tal consideração.

\footnotetext{
17 Dos participantes que responderam não, 4\% apresentaram mais de uma razão para essa resposta, por isso o
} número total de justificativas é superior à quantidade de entrevistados dessa categoria. 
Tabela 7

Obrigatoriedade da retribuição a uma ação generosa: distribuição conforme a idade das justificativas dos participantes que responderam não.

\begin{tabular}{lcccccccc}
\hline \multirow{2}{*}{ Justificativa } & \multicolumn{2}{c}{6 anos } & \multicolumn{2}{c}{9 anos } & \multicolumn{2}{c}{12 anos } & \multicolumn{2}{c}{ Geral } \\
\cline { 2 - 9 } & $\mathrm{N}^{\mathrm{o}}$ & $\%$ & $\mathrm{~N}^{\mathrm{o}}$ & $\%$ & $\mathrm{~N}^{\mathrm{o}}$ & $\%$ & $\mathrm{~N}^{\mathrm{o}}$ & $\%$ \\
\hline $\begin{array}{l}\text { Espontaneidade do agradecimento } \\
\text { e/ ou da retribuição }\end{array}$ & 11 & 84,6 & 12 & 66,7 & 11 & 57,9 & 34 & 68,0 \\
$\begin{array}{l}\text { Espontaneidade da generosidade } \\
\begin{array}{l}\text { Generalização da não } \\
\text { obrigatoriedade }\end{array}\end{array}$ & 0 & 0,0 & 3 & 16,7 & 4 & 21,0 & 7 & 14,0 \\
Outros & 0 & 0,0 & 2 & 11,1 & 2 & 10,5 & 4 & 8,0 \\
\hline
\end{tabular}

A maior parte dos participantes (68\%) mencionou a espontaneidade do agradecimento el ou da retribuição como argumento para a resposta negativa. Tal justificativa apareceu de maneiras variadas nas falas dos entrevistados. A grande maioria condicionou tal ato a um querer: "Porque, se ele não quiser, ele não é obrigado, depende da vontade dele" (Francisco, 9; 11). Alguns participantes, principalmente os mais novos, ressaltaram a ausência de uma coação externa quando se referiram à espontaneidade da ação em jogo:

Não obrigar, mas dizer assim: "Filho, você tem educação? Dá um obrigado para o seu amigo". Não é um gesto obrigatório do tipo: "Filho, dá 'obrigado' para ele" (com a voz mais alta e um tom autoritário). É um gesto carinhoso porque a mãe quer o bem do filho.... Bom, se ele não quiser, eu acho que ele tem a sua opinião também (Carlos, 9; 6).

Vejam que, na fala de Carlos, a polidez deve ser recomendada, e não imposta, pela figura de autoridade, no caso a mãe. Na pesquisa de La Taille (2001a) sobre essa "pequena virtude", a opção pela educação, e não pelo castigo, como reação à falta de polidez mostra sua singularidade nas faixas etárias de 9 e 12 anos, e a mesma opção já está presente na metade da amostra de 6 anos. Em uma de nossas pesquisas sobre a generosidade, investigamos se a ausência da virtude é merecedora de punição (Vale, 2006; Vale \& Alencar, 2008b). A conversa, e não a sanção, predomina nas faixas etárias de 7, 10 e 13 anos, e as porcentagens relativas aumentam com a idade. Tais dados, juntamente com os resultados do presente estudo, atestam que a criança já é capaz de compreender que nem a generosidade nem uma reação polida a sua manifestação correspondem a uma exigência social. 
Alguns entrevistados das últimas faixas etárias compararam o agradecimento e/ ou a retribuição com situações regidas por regras para demonstrar o caráter espontâneo do ato:

Não é obrigado a fazer. Só algumas coisas ele é obrigado a fazer, fazer prova, essas coisas.... Porque prova é para você aprender, se formar e ter um trabalho. E você não ganha nada para brincar, mas seu amigo vai ficar feliz (Mateus, 9; 7).

Em nossa pesquisa sobre ausência de generosidade e punição (Vale, 2006; Vale \& Alencar, 2008b), muitos participantes também estabeleceram uma comparação da falta da virtude com transgressões claramente morais (merecedoras de castigo) para mostrar a espontaneidade característica da ação generosa.

Destacamos a porcentagem relativa a essa categoria na primeira faixa de idade da pesquisa: $84,6 \%$ das crianças de 6 anos mencionaram a espontaneidade do agradecimento el ou da retribuição como justificativa. Considerando que a grande maioria dos participantes mais novos indicou exclusivamente a polidez como resposta a uma manifestação de generosidade, parece-nos pertinente afirmar que suas justificativas referentes à espontaneidade estão mais relacionadas à boa educação do que a qualquer outro tipo de retribuição. Não podemos afirmar o mesmo sobre as outras faixas etárias, onde a "pequena virtude" aparece associada a algum tipo de retribuição, que, muitas vezes, nos remete à gratidão. Embora a porcentagem concernente a essa categoria decresça com o avanço da idade, permanece em evidência entre os participantes mais velhos, que apresentaram também uma outra justificativa: espontaneidade da generosidade.

Nessa categoria, os entrevistados justificaram a não obrigatoriedade do agradecimento e/ ou da retribuição pela não obrigatoriedade da manifestação de generosidade: "Porque o Fernando (a personagem generosa) está fazendo isso por vontade própria, e não tipo: 'Eu estou fazendo isso, mas, depois, você vai ter que fazer alguma coisa por mim'” (Daniel, 12; 6). Segundo esses participantes, não há uma obrigação em jogo porque a ação generosa foi realizada de forma livre e gratuita, sem o intuito de colocar a personagem beneficiada em dívida, exigindo-lhe qualquer retribuição. Uma apreciação da intenção do autor do ato generoso, pressuposta pela gratidão propriamente dia, pode ser notada nas justificativas incluídas nessa categoria. Se nos atentarmos à Tabela 7, veremos que tais argumentações só aparecem a partir dos 9 anos de idade, exatamente quando a moral da responsabilidade subjetiva começa a predominar sobre a moral da responsabilidade objetiva (Piaget, 1932/1994). 
É importante ressaltar também que, com o pensamento organizado pela lógica, as crianças dessas faixas etárias se tornam capazes de estabelecer relações consistentes entre os enunciados e de coordenar os pontos de vista entre si. Com a passagem da intuição à lógica, “(...) as noções e relações não se podem construir isoladamente, mas constituem organizações de conjuntos, nas quais todos os elementos são solidários e se equilibram entre si” (Piaget, 1964/2003, p. 52). Nossos participantes mais velhos que apresentaram justificativas da referida categoria, provavelmente, possuem ferramentas intelectuais que os permitem articular as virtudes em jogo, e não apenas centrar naquilo que lhe é apresentado diretamente na pergunta de investigação (agradecimento e/ ou retribuição), como o fizeram as crianças pequenas.

Uma outra categoria de justificativa é a generalização da não obrigatoriedade, que apareceu, com uma porcentagem baixa, nas duas últimas faixas etárias do estudo: "Porque ninguém é obrigado a nada, ele faz se ele quiser" (Breno, 12; 5). Esse tipo de argumentação nos surpreende quando nos deparamos com a enorme quantidade de regras que se abate sobre a sociedade contemporânea. De acordo com La Taille (2009a), há, nos dias de hoje, uma infantilização do cidadão:

Ele é incessantemente tutelado e vigiado, como se fosse criança pequena. E, também como criança, procura, sem ser visto, transgredir regras que não fazem, para ele, sentido e que o incomodam. Para impedir tais transgressões, criam-se mais regras, que implicam mais formas de controle, em uma dialética sem fim (p. 194).

Segundo o autor, a "tirania da regra" enterra os princípios e promove o "crepúsculo do dever”. Forçadas a cumprir tantas regras impostas e vigiadas constantemente, as pessoas não são levadas a desenvolver um controle interno e carecem, dessa forma, do sentimento de obrigatoriedade. Será que é a carência dessa obrigatoriedade que esses poucos participantes generalizam aqui? Nesse caso, não poderíamos dizer que "ninguém é obrigado a nada", mas que ninguém se sente obrigado a nada. "A moral adormece no espírito de cada um" (La Taille, 2009a, p. 194). Mas discutamos ainda um último dado que nos oferece uma ponta de otimismo moral, pelo menos no que tange ao tema de virtudes como a generosidade, a gratidão e a polidez.

Metade dos participantes que disse não à obrigação de agradecer e/ ou retribuir ressaltou que, embora o agradecimento ou a retribuição a uma ação generosa seja desprovido de obrigatoriedade, tal atitude é digna de admiração; a sua ausência é reprovável ou, ainda, que, se estivesse na mesma situação, optaria por agradecer e/ ou retribuir o ato de generosidade. 
Tais ressalvas foram encontradas nas respostas e/ ou justificativas dos participantes de 9 e 12 anos, com as porcentagens de $61,1 \%$ e $78,9 \%$, respectivamente.

(...) mas, se fosse eu, eu acharia obrigatório você retribuir.... já que o Fernando fez por vontade própria, você deve se sentir na obrigação de retribuir a ele, fazer uma coisa boa da mesma forma que ele fez uma boa coisa por você (César, 12; 9).

Vejam que César não fala de um dever derivado de um direito alheio, mas de um dever como um tipo particular de querer, o "querer fazer moral” (La Taille, 2006b, p. 108). É ele mesmo quem coloca para si a obrigação de retribuir à generosidade recebida. $\mathrm{O}$ mesmo pode ser observado na fala de Ronaldo (12; 3): "Para mim, seria um compromisso porque ele é meu amigo. Mas ele não vai assinar nenhum contrato para falar isso”. Tais participantes parecem experimentar aqui o sentimento de obrigatoriedade, que, como vimos, não corresponde necessariamente a uma exigibilidade social do comportamento decorrente. É interessante destacar que tais ressalvas só aparecem nas últimas faixas etárias do estudo. As crianças mais novas, embora já demonstrem valorizar o agradecimento e/ ou a retribuição à generosidade, não expressam em suas respostas esse sentimento de dever, que, como vimos, em fase de heteronomia, ainda é exterior à consciência (Piaget, 1932/1994). As ressalvas de alguns de nossos entrevistados mais velhos já nos remetem a uma moral autônoma, e a retribuição (ou agradecimento) à generosidade representa para eles um genuíno dever.

Conforme relatamos anteriormente, Castro et al. (2011), ao investigarem as razões pelas quais, segundo crianças de 5 a 12 anos, se deve ou não retribuir, verificaram que a retribuição como um bem moral aparece apenas nas falas de 30\% das crianças de 11-12 anos. Os resultados de nossa pesquisa são mais animadores, já que essa argumentação atinge porcentagens muito mais altas e abarca também a faixa etária de 9 anos.

Vale mencionar, por fim, as justificativas apresentadas por aqueles participantes que responderam de forma afirmativa a nossa última questão. A maior parte deles $(62,5 \%)$ citou a generosidade associada à abdicação de um interesse próprio como razão para a obrigatoriedade do agradecimento e/ ou da retribuição, e $25 \%$ deles (todos da menor faixa etária) mencionaram a amizade como argumento para a resposta afirmativa.

Vamos agora aos dados referentes à segunda história deste estudo, que aborda dois tipos específicos de retribuição. Tais dados certamente complementarão os resultados até aqui apresentados. 


\subsubsection{História 2}

Vimos que, na segunda história, duas personagens beneficiadas por uma manifestação de generosidade apresentam dois tipos de retribuição à personagem generosa: a recompensa material e a demonstração verbal de reconhecimento do que lhe foi feito por outrem. Inicialmente, perguntamos aos nossos participantes se as duas personagens agiram bem. Se, na primeira história, todos os entrevistados julgaram que uma personagem deve agradecer e/ ou retribuir àquele que lhe foi generoso, parece-nos válido supor que a resposta a essa pergunta não poderá ser outra: sim. E, de fato, este foi o resultado encontrado: todos os participantes responderam que as duas personagens agiram bem ao retribuírem o que lhes foi feito por outrem. Vale destacar que a demonstração verbal de reconhecimento, indicada espontaneamente por apenas um participante de 6 anos na primeira história, é aqui valorizada por todos os entrevistados, inclusive os mais novos, já que aprovaram a conduta da personagem que assim agiu.

Em seguida, perguntamos aos nossos participantes: por que as personagens agiram bem? E suas justificativas confirmam: é a retribuição, efetuada de duas formas distintas, que os leva a aprovar as duas condutas em jogo. Conforme pode ser observado na Tabela 8, a maioria dos entrevistados $(61,7 \%)$ justifica dessa maneira:

Eu acho que elas agiram bem porque elas deram um "obrigado" de uma forma boa. A Paula deu um "obrigado" falando "sem a sua ajuda, eu não teria ganhado; isso, isso e aquilo”. E a Marcela falou um "obrigado" dando um presente para a Gabriela, é um tipo de "obrigado" (Nicole, 12; 4).

Tabela 8

Por que as personagens que retribuíram a uma ação generosa agiram bem? - distribuição das justificativas dos participantes conforme a idade

\begin{tabular}{lcccccccc}
\hline \multirow{2}{*}{ Justificativa } & \multicolumn{2}{c}{6 anos } & \multicolumn{2}{c}{9 anos } & \multicolumn{2}{c}{12 anos } & \multicolumn{2}{c}{ Geral } \\
\cline { 2 - 8 } & $\mathrm{N}^{\mathbf{0}}$ & $\%$ & $\mathrm{~N}^{\mathrm{o}}$ & $\%$ & $\mathrm{~N}^{\mathrm{o}}$ & $\%$ & $\mathrm{~N}^{\mathrm{o}}$ & $\%$ \\
\hline $\begin{array}{l}\text { Retribuição } \\
\begin{array}{l}\text { Retribuição como consequência } \\
\text { da generosidade }\end{array}\end{array}$ & 14 & 70,0 & 13 & 65,0 & 10 & 50,0 & 37 & 61,7 \\
$\begin{array}{l}\text { Outros } \\
\text { Total }\end{array}$ & 2 & 10,0 & 0 & 0,0 & 0 & 0,0 & 2 & 3,3 \\
\hline
\end{tabular}


Prosseguindo com a Tabela 8 , podemos verificar que $35 \%$ dos participantes foram um pouco mais longe e mencionaram a retribuição como consequência da generosidade em suas justificativas: “(...) eles fizeram uma coisa boa para ele porque ele fez uma coisa boa para eles antes. Eles retribuíram um favor” (Joaquim, 12; 2). Tais entrevistados falam, em suas argumentações, de uma articulação entre as virtudes, que, de fato, não são independentes uma das outras (La Taille, 2001b). Segundo Comte-Sponville (1995/1997), a gratidão nutre a generosidade, que nutre a gratidão. A generosidade pode se articular à gratidão, que pode se articular a tantas outras virtudes: "o que a gratidão ensina é que existe também uma humildade alegre, ou uma alegria humilde, porque ela sabe que não é a sua própria causa, nem seu próprio princípio" (Comte-Sponville, 1995/1997, p. 148).

Se nos atentarmos aos resultados dessa categoria referentes às faixas etárias pesquisadas, podemos averiguar que as porcentagens relativas aumentam com a idade. É possível que a estruturação cognitiva exerça influência aqui. É o pensamento, organizado pela lógica, das crianças mais velhas que, certamente, contribui para o estabelecimento de relações consistentes entre as virtudes em questão.

Conhecidas as justificativas referentes à primeira pergunta, avancemos um pouco mais. Perguntamos, em seguida, aos nossos entrevistados se uma das personagens agiu melhor do que a outra e, como pode ser visto na Figura 4, as respostas ficaram bastante divididas.

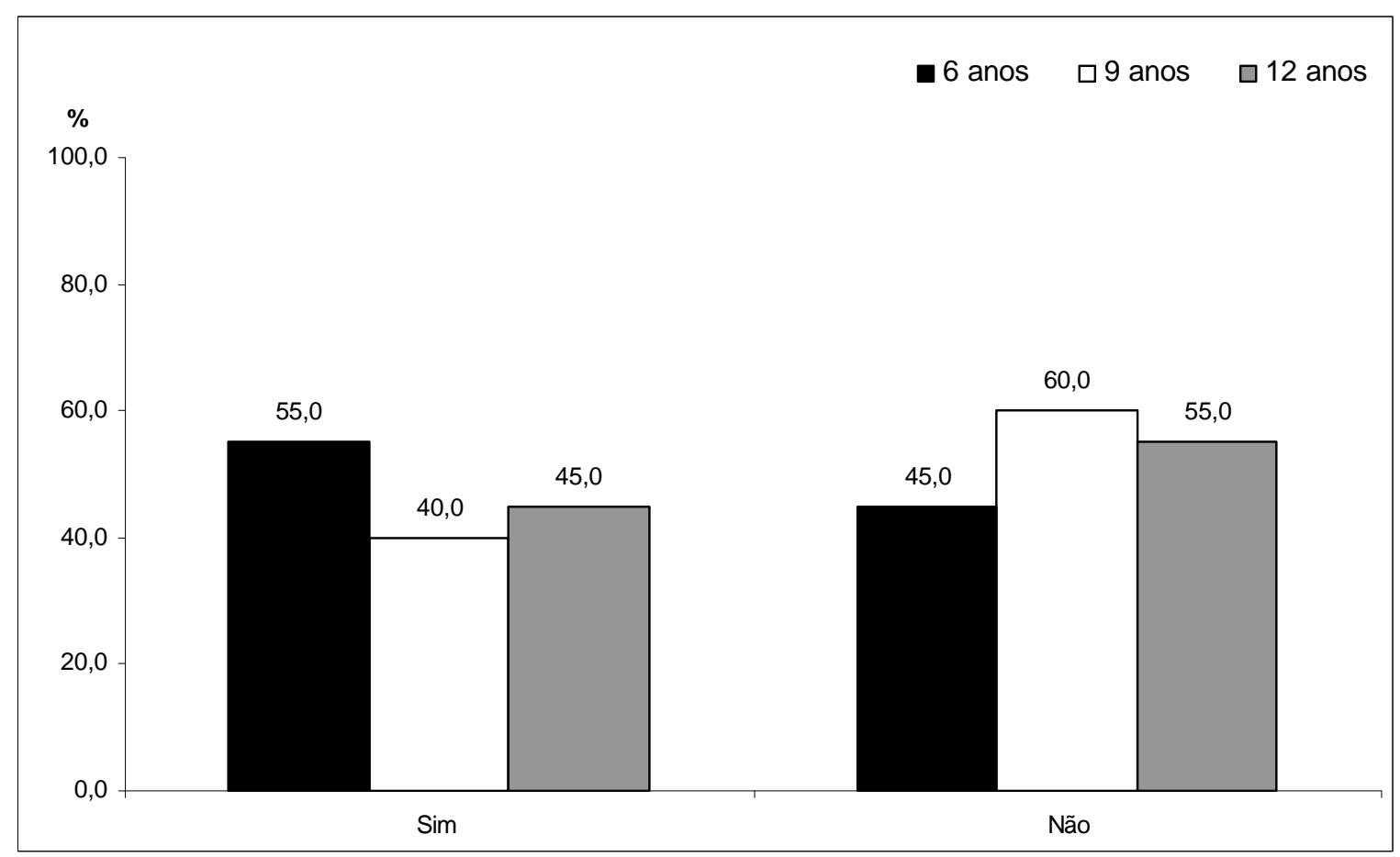

Figura 4. Um tipo de retribuição é mais valorizado do que o outro? - comparação das respostas dos participantes conforme a idade 
Se o veredicto de nossos participantes nada nos esclarece em um primeiro momento, vamos adiante e conheçamos suas razões. Comecemos com as justificativas daqueles que apresentaram uma resposta negativa (Tabela 9).

Tabela 9

Por que um tipo de retribuição não é mais valorizado do que o outro? - distribuição conforme a idade das justificativas dos participantes que responderam não.

\begin{tabular}{lcccccccc}
\hline \multirow{2}{*}{ Justificativa } & \multicolumn{2}{c}{6 anos } & \multicolumn{2}{c}{9 anos } & \multicolumn{2}{c}{12 anos } & \multicolumn{2}{c}{ Geral } \\
\cline { 2 - 9 } & $\mathrm{N}^{\circ}$ & $\%$ & $\mathrm{~N}^{\circ}$ & $\%$ & $\mathrm{~N}^{\circ}$ & $\%$ & $\mathrm{~N}^{\circ}$ & $\%$ \\
\hline Retribuição & 8 & 88,9 & 7 & 58,3 & 6 & 54,5 & 21 & 65,6 \\
$\begin{array}{l}\text { Equivalência entre as duas formas } \\
\text { de retribuição }\end{array}$ & 0 & 0,0 & 4 & 33,3 & 5 & 45,5 & 9 & 28,1 \\
Outros & 1 & 11,1 & 1 & 8,4 & 0 & 0,0 & 2 & 6,3 \\
\hline Total & 9 & 100,0 & 12 & 100,0 & 11 & 100,0 & 32 & 100,0 \\
\hline
\end{tabular}

Como pode ser observado na Tabela 9, a retribuição também prevalece como justificativa aqui. A maioria dos entrevistados que não considera que uma das personagens agiu melhor do que a outra $(65,6 \%)$ argumenta que ambas retribuíram, cada uma a sua maneira: “(..) porque cada uma agradeceu do seu jeito. Vai ver que uma era muito tímida, não sabia agradecer e deu uma caixa de bombons" (Lorena, 9; 11). Vejam que há uma predominância desse argumento em todas as faixas etárias, porém as porcentagens relativas ao mesmo diminuem nas duas últimas idades pesquisadas, onde encontramos uma outra categoria de justificativa: equivalência entre as duas formas de retribuição.

Quase a metade dos participantes de 12 anos (45,5\%) e 33,3\% dos entrevistados de 9 anos que apresentaram uma resposta negativa atribuíram, em suas justificativas, igual valor não apenas às condutas de ambas as personagens (que retribuíram), mas aos dois tipos de retribuição efetuados: “(...) acho que foi igual porque todas essas coisas: bombons, presentes, falar um monte de coisas, dizer 'obrigado', tudo faz parte de uma simples palavra, tudo vale a mesma coisa" (Carlos, 9; 6). Os entrevistados que fizeram uso desse tipo de argumentação conferem igual importância aos aspectos materiais e abstratos das retribuições:

Bom, os dois tiveram a intenção de agradecer e ver que a pessoa ajudou e quis fazer assim. Mas levar uma caixa de bombons vai significar a mesma coisa de dar um abraço, ir lá, falar, conversar... (...) eles agiram da mesma forma, só que um quis gastar o dinheiro para comprar uma coisa material para ele na forma dele de agradecer, 
e o outro foi lá com um gesto de carinho. Aí, eu acho que não tem certo nem errado. Os dois estão certos, só que um materializa mais as suas palavras, e o outro usa a voz para conversar, agradecer, falar coisas boas (Leonardo, 12; 8).

Vimos anteriormente que, conforme o sistema de pensamento infantil se torna mais amplo e complexo, mais a criança se torna capaz de incluir em seus juízos elementos abstratos, e não somente aspectos materiais da realidade (Souza, 2007). Aqui está uma possível explicação para essa categoria de justificativa prevalecer na idade de 12 anos e inexistir na menor faixa etária do estudo.

Àqueles participantes que apresentaram uma resposta afirmativa, perguntamos qual das duas personagens agiu melhor e, como pode ser notado na Figura 5, encontramos um indício de gênese. Urge matizar aqui que essa gênese só diz respeito à aproximadamente metade de nossos entrevistados, já que, como vimos, o restante atribuiu igual valor às duas formas de retribuição apresentadas.

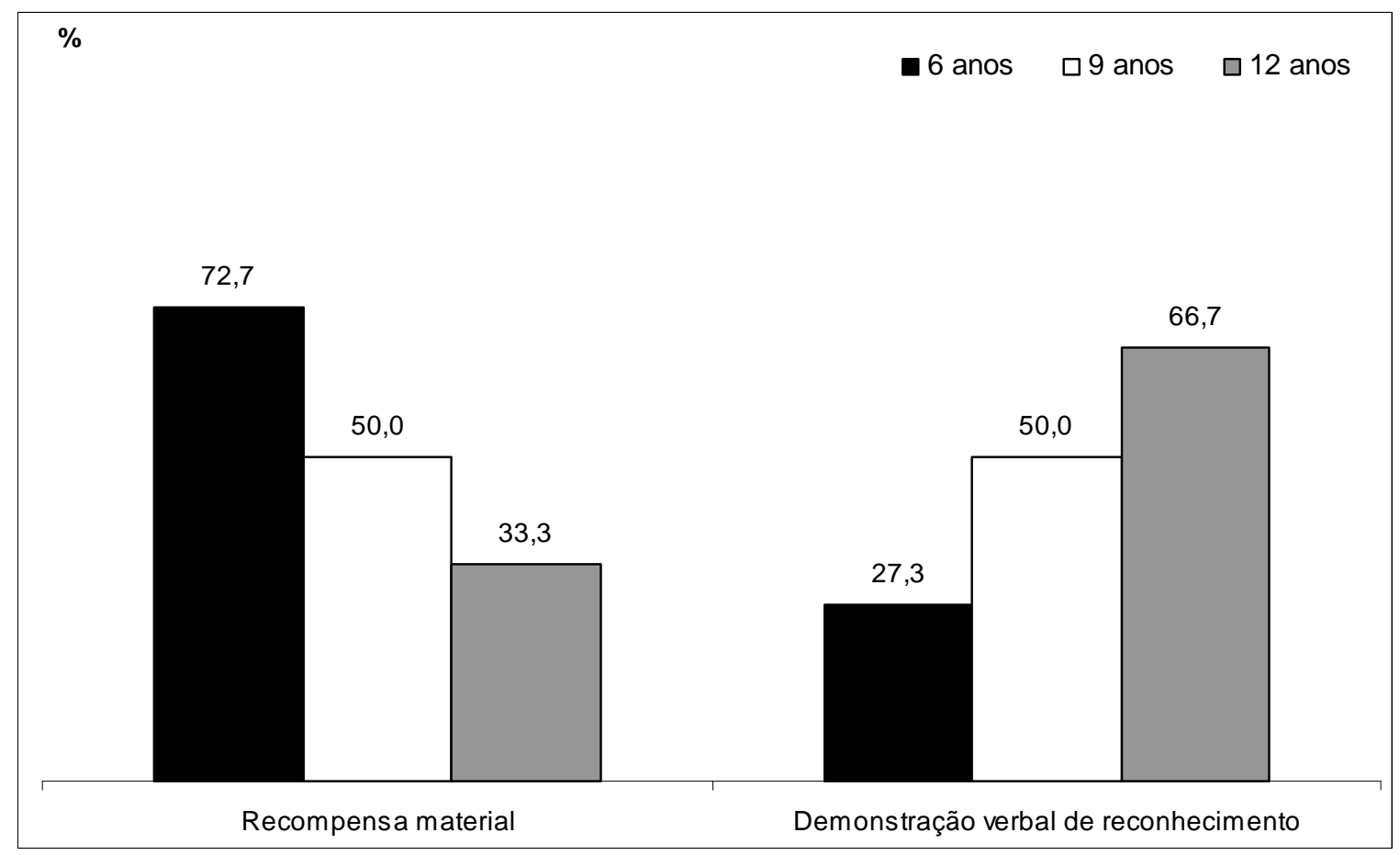

Figura 5. Tipo de retribuição mais valorizado pelos participantes que responderam sim: comparação das respostas conforme a idade 
De acordo com nossa hipótese, a recompensa material prevaleceria nos juízos das crianças mais novas, e a demonstração verbal de reconhecimento deveria comparecer apenas nas respostas de nossos participantes mais velhos. Vimos que, na primeira história, a recompensa material só aparece nas respostas das crianças de 6 anos, mas não é a categoria predominante nessa faixa etária, perdendo espaço para a polidez nas sugestões espontâneas de agradecimento e/ ou retribuição dos participantes mais novos. A demonstração verbal de reconhecimento praticamente não aparece entre as crianças menores na história 1, mas também não ganham muita evidência nas últimas faixas etárias estudadas. Aqui, a pertinência de nossa hipótese se torna mais clara: diante das duas opções de retribuição, os mais novos atribuem maior valor à recompensa material; os mais velhos, à demonstração verbal de reconhecimento; e a faixa etária intermediária se mostra dividida entre os dois tipos de retribuição, um indicativo de gênese, portanto. Ao investigar as diferentes formas de manifestação da gratidão ao longo do desenvolvimento, Pieta (2009) também verificou um decréscimo com o avanço da idade na frequência da retribuição com bens materiais.

A maioria dos participantes que atribuiu maior valor à recompensa material (60\%) ressaltou, como o próprio nome já diz, o aspecto material da retribuição em suas justificativas: "Porque ele deu uma caixa de bombons... Porque tem chocolate por fora e, por dentro, baunilha" (Leandro, 6; 3). E 40\% desses entrevistados mencionaram em suas argumentações que a recompensa material é superior à demonstração verbal de reconhecimento: "Porque é mais fácil guardar o bombom do que lembrar a palavra" (Tales, $9 ; 5)$.

Vamos agora às categorias de justificativa referentes àqueles participantes que conferiram maior importância à demonstração verbal de reconhecimento (Tabela 10) ${ }^{18}$.

Quase a metade dos entrevistados que optaram por esse tipo de retribuição $(46,1 \%)$ mencionou que a demonstração verbal de reconhecimento é superior à recompensa material:

Uma caixa de bombom pode ser melhor, em alguns sentidos, do que um agradecimento, mas ver uma pessoa feliz é ainda melhor. A caixa de bombons pode ser um objeto, mas ver uma pessoa feliz agradecendo é melhor... porque, no agradecimento, é uma pessoa feliz falando para o outro o que achou do que ele fez por ela (Joaquim, 12; 2).

\footnotetext{
18 Vale dizer que 30,8\% dos participantes que decidiram pela demonstração verbal de reconhecimento apresentaram mais de uma razão para suas respostas, por isso o número total de justificativas é superior à quantidade de entrevistados dessa categoria.
} 
Tabela 10

Distribuição conforme a idade das justificativas dos participantes que decidiram pela demonstração verbal de reconhecimento

\begin{tabular}{lcccccccc}
\hline \multirow{2}{*}{ Justificativa } & \multicolumn{2}{c}{6 anos } & \multicolumn{2}{c}{9 anos } & \multicolumn{2}{c}{12 anos } & \multicolumn{2}{c}{ Geral } \\
\cline { 2 - 8 } & $\mathrm{N}^{\mathrm{o}}$ & $\%$ & $\mathrm{~N}^{\mathrm{o}}$ & $\%$ & $\mathrm{~N}^{\mathrm{o}}$ & $\%$ & $\mathrm{~N}^{\mathrm{o}}$ & $\%$ \\
\hline $\begin{array}{l}\text { A demonstração verbal de } \\
\text { reconhecimento é superior à } \\
\text { recompensa material }\end{array}$ & 0 & 0,0 & 3 & 75,0 & 3 & 50,0 & 6 & 46,1 \\
$\begin{array}{l}\text { A polidez é superior à recompensa } \\
\text { material }\end{array}$ & 3 & 100,0 & 1 & 25,0 & 1 & 16,7 & 5 & 38,5 \\
$\begin{array}{l}\text { Momento em que a retribuição foi } \\
\text { manifestada }\end{array}$ & 0 & 0,0 & 2 & 50,0 & 4 & 66,7 & 6 & 46,1 \\
\hline
\end{tabular}

Vimos que a demonstração verbal de reconhecimento, tão apreciada pelo participante citado acima, pressupõe uma avaliação da intenção daquele que manifestou a generosidade, fundamental na manifestação da gratidão propriamente dita (Bonnie e de Wall, 2004). Vimos também que só por volta dos 9 anos de idade é que a criança passa a utilizar a intencionalidade como um critério necessário para julgar moralmente uma dada situação (Piaget, 1932/1994). Se nos atentarmos à Tabela 10, verificaremos que tal categoria só aparece a partir dessa idade. É possível, portanto, que a moral da responsabilidade subjetiva leve nossos participantes mais velhos a atribuírem maior valor à demonstração verbal de reconhecimento e, portanto, à gratidão. Não pretendemos dizer com isso que a recompensa material não possa ser uma autêntica expressão da virtude, mas que, na situação apresentada, o reconhecimento de uma dívida para com outrem se torna mais evidente na demonstração verbal de uma das personagens do que na caixa de bombons entregue pela outra.

Não encontramos a referida categoria de justificativa entre as crianças de 6 anos. Vimos, porém, que algumas delas dizem preferir a atitude da personagem que retribui com uma demonstração verbal de reconhecimento. Mas se a demonstração verbal de reconhecimento pressupõe uma avaliação da intenção do outro, e a criança pequena ainda não utiliza a intencionalidade como critério necessário para julgar um ato, como podemos explicar tal preferência de alguns participantes de 6 anos? A categoria seguinte da Tabela 10 nos ajuda a encontrar a resposta.

Todos os participantes de 6 anos que atribuíram maior valor à demonstração verbal de reconhecimento destacaram apenas o simples "obrigado" do discurso de agradecimento da personagem: “Porque ele disse 'obrigado', e o outro, não" (George, 6; 7). É à polidez, e não à gratidão, que tais entrevistados se referem quando julgam que a conduta dessa personagem é superior, por isso, incluímos suas justificativas na categoria a polidez é superior à 
recompensa material. Ora já vimos que o emprego das regras simples e precisas dessa "pequena virtude" não exige reflexão e pode se restringir a uma interpretação ao pé da letra, característica central da heteronomia infantil.

É importante mencionar ainda que o momento em que a retribuição foi manifestada (logo depois da premiação do concurso, e não no dia seguinte) também apareceu nas justificativas dos participantes de 9 e 12 anos que optaram pela demonstração verbal de reconhecimento: "Eu acho que a Marcela deveria ter agradecido na hora, como a Paula fez.... Você tem que agradecer na hora, não depois. A pessoa gosta quando agradece na hora (...)” (Anita, 12; 4).

Conheçamos agora os resultados referentes à terceira e última história deste estudo, verificando se a possibilidade de retribuição interfere nos juízos dos entrevistados a respeito da manifestação de generosidade de uma pessoa para com outra.

\subsubsection{História 3}

A terceira história deste estudo traz uma situação escolar cotidiana em que uma personagem, que possui um pacote com dez biscoitos, está diante de duas outras personagens com fome e sem nada para comer. Uma das personagens com fome costuma retribuir às ações generosas que recebe, e a outra, não. Inicialmente, perguntamos aos nossos participantes o que a personagem com o pacote de biscoitos deve fazer. A grande maioria deles $(88,3 \%)$ decidiu pela generosidade para com ambas as personagens: "Eu acho que a menina que estava com os dez biscoitos deveria dar para as duas, mesmo a outra sendo 'pão dura", (Nicole, 12; 4). Como pode ser observado na Figura 6, essa resposta prevalece em todas as faixas etárias, o que nos leva a crer que a possibilidade de retribuição não interfere nos juízos sobre a generosidade da maior parte dos entrevistados de todas as idades pesquisadas. 


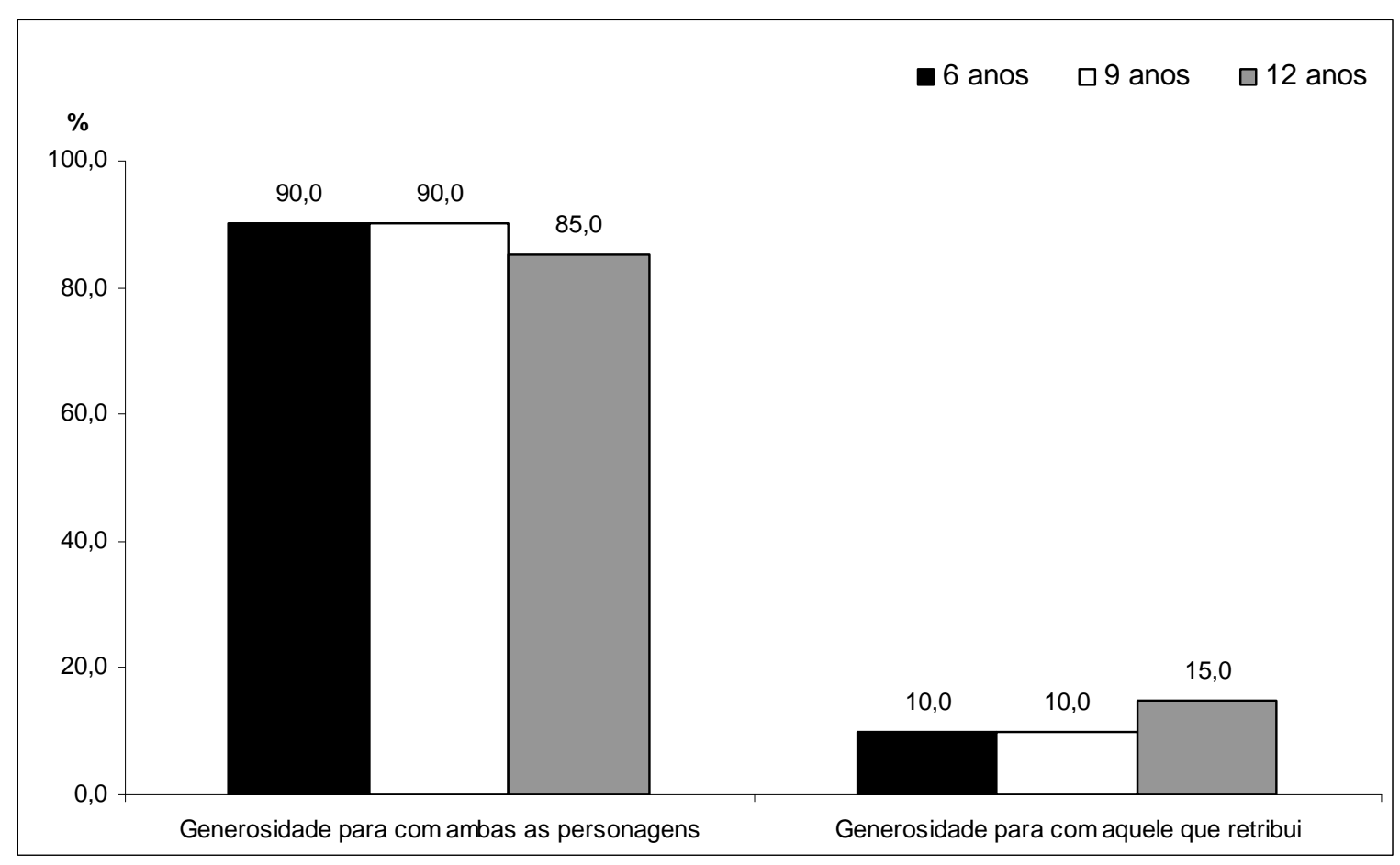

Figura 6. Influência da possibilidade de retribuição na manifestação de generosidade: comparação das respostas dos participantes conforme a idade

No que diz respeito à variedade de justificativas dos participantes que decidiram pela generosidade para com ambas as personagens, distribuímo-las em sete categorias, que podem ser conferidas a seguir (Tabela 11) ${ }^{19}$.

Conforme a Tabela 11, a maior parte dos entrevistados que decidiram pela generosidade para com ambas as personagens $(64,1 \%)$ mencionou as circunstâncias de quem precisava de ajuda em suas justificativas: "Porque elas estão com muita fome e, também, quando um ser humano está com fome, ele pode ficar meio sonolento porque ele não tem energia, e isso o prejudicaria a fazer os deveres” (Joana, 9; 7). Esse tipo de argumentação, como já vimos, nos remete à simpatia, e nossos dados comprovam mais uma vez a íntima relação desse sentimento com a manifestação de generosidade.

Embora a porcentagem relativa a essa categoria seja alta em todas as faixas etárias, a mesma predomina na menor idade pesquisada e decresce nas idades seguintes (Tabela 11). Tal resultado parece, mais uma vez, alentar a hipótese de que é mesmo a simpatia que inspira

19 É importante saber que 26,4\% dos participantes que decidiram pela generosidade para com ambas as personagens apresentaram mais de uma razão para suas respostas, por isso o número total de justificativas é superior à quantidade de entrevistados dessa categoria. 
as crianças pequenas a decidirem por uma ação generosa para com o outro. Não pretendemos dizer com isso que o mesmo sentimento não possa infundir a mesma decisão nos mais velhos, haja vista a alta porcentagem dessa categoria nas outras idades também. O que defendemos mais uma vez aqui, diante de novos dados, é que, nas faixas etárias mais avançadas, outros critérios passam a regular os juízos que culminam em uma decisão pela generosidade. A justificativa apresentada por Anita $(12 ; 4)$ esclarece o que estamos defendendo: "Porque ela estava com fome. Você sempre tem que se colocar no lugar dos outros para ver como é. Se você estivesse com fome, a outra pessoa deveria te dar”. Vejam que, na argumentação dessa participante de 12 anos, a comoção com o estado alheio está aliada a uma moral da reciprocidade, já que ela sugere tratar o outro como gostaria de ser tratada.

Tabela 11

Influência da possibilidade de retribuição na manifestação de generosidade: distribuição conforme a idade das justificativas dos participantes que decidiram pela generosidade para com ambas as personagens.

\begin{tabular}{|c|c|c|c|c|c|c|c|c|}
\hline \multirow{2}{*}{ Justificativa } & \multicolumn{2}{|c|}{6 anos } & \multicolumn{2}{|c|}{9 anos } & \multicolumn{2}{|c|}{12 anos } & \multicolumn{2}{|c|}{ Geral } \\
\hline & $\mathrm{N}^{\mathrm{o}}$ & $\%$ & $\mathrm{~N}^{\mathrm{o}}$ & $\%$ & $\mathrm{~N}^{\mathrm{o}}$ & $\%$ & $\mathrm{~N}^{\mathrm{o}}$ & $\%$ \\
\hline $\begin{array}{l}\text { Circunstâncias de quem precisava } \\
\text { de ajuda }\end{array}$ & 16 & 88,9 & 12 & 66,7 & 6 & 35,3 & 34 & 64,1 \\
\hline Um erro não justifica o outro & 0 & 0,0 & 0 & 0,0 & 6 & 35,3 & 6 & 11,3 \\
\hline $\begin{array}{l}\text { Atitude admirável e/ ou associada } \\
\text { a valores morais }\end{array}$ & 1 & 5,5 & 6 & 33,3 & 2 & 11,8 & 9 & 17,0 \\
\hline Amizade & 4 & 22,2 & 4 & 22,2 & 0 & 0,0 & 8 & 15,1 \\
\hline Para aprender a retribuir & 0 & 0,0 & 3 & 16,7 & 2 & 11,8 & 5 & 9,4 \\
\hline $\begin{array}{l}\text { Irrelevância da ausência de } \\
\text { retribuição }\end{array}$ & 0 & 0,0 & 1 & 5,5 & 3 & 17,6 & 4 & 7,5 \\
\hline Reciprocidade pragmática & 0 & 0,0 & 2 & 11,1 & 2 & 11,8 & 4 & 7,5 \\
\hline
\end{tabular}

Um outro argumento utilizado pelos entrevistados de 12 anos que decidiram pela generosidade para com ambas as personagens (35,3\% deles) foi: um erro não justifica o outro. "Porque um erro não justifica o outro. No caso, não era um erro, mas não é porque ele é 'pão duro' que ele não merece ganhar como a gente” (Mário, 12; 6). A generosidade indicada por esses participantes não está baseada nas relações de troca do tipo "toma lá, dá cá”: “Não é só porque o Bruno está no nível de 'pão duro' que ele vai ter que se igualar ao Bruno, fazendo o mesmo ato que ele faz no colégio" (Breno, 12; 5). Parece haver nas 
justificativas dessa categoria um compromisso com um princípio geral que possa balizar as decisões apresentadas, um princípio que tenha validade independente das consequências imediatas da ação, independente, nesse caso, da possibilidade de retribuição.

Eu acho que cada um deve praticar uma ação boa, mesmo que a outra não goste de fazer isso. Você não pode seguir o exemplo dela, senão, você pega a mania dela e começa a fazer o que ela faz, começa a não ter bons modos. Então, eu acho que, mesmo a pessoa não fazendo a coisa certa, você deve retribuir porque você não pode pegar o exemplo dela (Nicole, 12; 4)

Ainda de acordo com a Tabela 11, a categoria atitude admirável el ou associada a valores morais aparece entre os participantes de todas as idades que decidiram por ajudar ambas as personagens, com uma porcentagem mais alta na faixa etária de 9 anos. Nesses argumentos, há citações de valores como solidariedade, generosidade e educação. "Para ele ser solidário, não ser egoísta com as outras pessoas” (Luiz, 9; 8).

A amizade aparece nos argumentos dos entrevistados de 6 e 9 anos que decidiram pela generosidade para com as duas personagens (Tabela 11): "Porque eles são amigos, e os amigos sempre ajudam o outro, quase sempre ajudam" (Fábio, 6; 4). Vimos que, no estudo 1, esta foi uma justificativa comum entre os participantes que optaram pela generosidade. $\mathrm{Na}$ primeira história do presente estudo, o mesmo vínculo levou alguns entrevistados a indicarem o agradecimento e/ ou a retribuição a uma ação generosa. Não podemos negar, portanto, a relação da amizade com a manifestação de generosidade. No capítulo anterior, apresentamos algumas pesquisas que vão ao encontro desses dados. Convém ressaltar, todavia, que aqui, como nas histórias anteriores, as personagens não foram apresentadas como amigas, mas tomadas como tais por alguns participantes. Essa particularidade nos leva, mais uma vez, a destacar a generalização do conceito de amigo nas relações sociais contemporâneas (La Taille, 2009).

Alguns participantes decidiram ajudar as duas personagens para que aquela considerada "pão duro" pudesse aprender a retribuir: “(...) porque, se os outros forem educados com ela, de repente, ela pega o jeito e fica também mais educada” (Nicole, 12; 4). Como pode ser notado na Tabela 11, essa categoria apareceu, em pequenas porcentagens, nas duas últimas faixas de idade pesquisadas, onde também encontramos a categoria seguinte da referida tabela: irrelevância da ausência de retribuição. "Porque a gente não faz as coisas pensando no que a gente vai receber, e sim pensando na pessoa” (Giovana, 12; 4). Não há nesse tipo de justificativa uma preocupação com as relações de trocas concretas, característica do início do desenvolvimento moral infantil. Tal preocupação pode ser notada na última categoria da 
Tabela 11, reciprocidade pragmática, que aqui também só aparece nas faixas etárias de 9 e 12 anos. "Porque, quando ele precisar, alguém vai dar para ele porque ele deu para alguém" (Mário, 9; 6).

Na Figura 6, vimos que uma minoria dos participantes decidiu pela generosidade para com aquele que retribui: “A outra que não retribui deveria passar fome (...)” (Tatiana, 6; 2). A grande maioria desses participantes $(85,7 \%)$ apresentou como justificativa a ausência de retribuição da personagem "pão duro", o que só confirma que a possibilidade (nesse caso, a impossibilidade) de retribuição, de fato, influencia seus juízos a respeito da manifestação de generosidade para com o outro.

Quase a metade dos mesmos entrevistados (42,8\%) também apresentou a justificativa para aprender a retribuir: "Já que o Bruno estava fazendo coisas erradas e, ainda, não se conscientizava, eu acho que ele não merece. Porque ele tem que aprender, enxergar, acordar e fazer as coisas certas" (César, 12; 9). Esse argumento, utilizado por participantes de todas as idades, nos remete à justiça retributiva, mais especificamente a um dos tipos de sanção por reciprocidade mencionado por Piaget (1932/1994): fazer com aquele que cometeu a falta algo semelhante àquilo que ele fez . O autor deixa claro que esse castigo só é legítimo quando há uma preocupação em fazer o outro compreender o alcance de sua ação. Ora, se nos atentarmos à fala de César, que ilustra as justificativas dessa categoria, parece ser este o objetivo da recusa desses entrevistados à generosidade para com a personagem "pão duro".

Continuemos com nossas questões de investigação. Perguntamos àqueles participantes que decidiram pela generosidade para com ambas as personagens, quantos biscoitos cada uma delas deveria receber. A maioria deles $(73,6 \%)$ sugeriu a divisão igual do lanche. Como pode ser observado na Figura 7, essa resposta prevalece em todas as faixas etárias, o que nos leva a crer que a possibilidade de retribuição também não interfere na intensidade da ação generosa indicada pela maior parte dos entrevistados de todas as idades pesquisadas. 


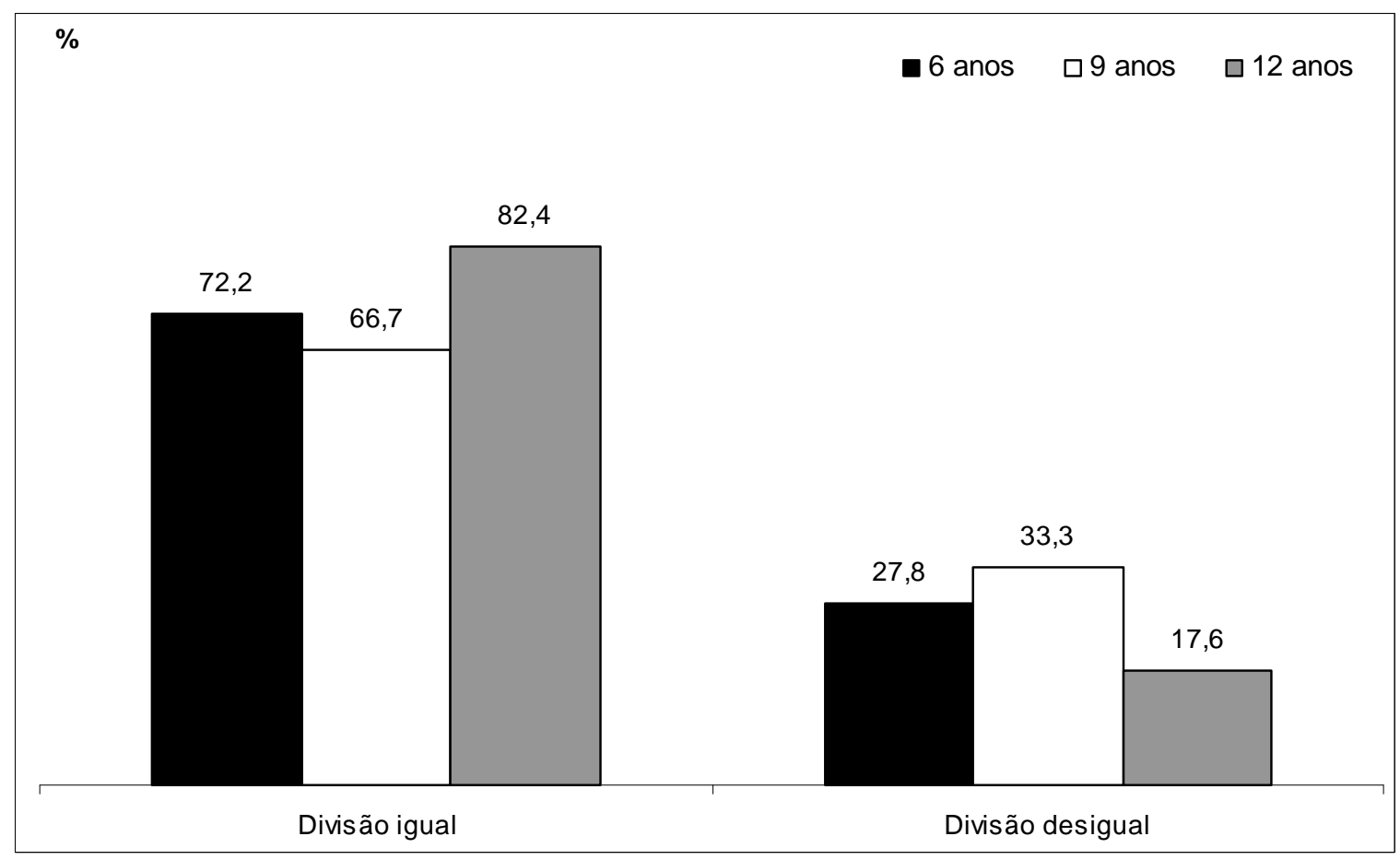

Figura 7. Influência da possibilidade de retribuição na intensidade da ação generosa: distribuição conforme a idade das respostas dos participantes que decidiram pela generosidade para com ambas as personagens

Urge ressaltar que as respostas incluídas na categoria divisão igual apresentam certas variações. Alguns participantes sugeriram que o lanche fosse distribuído igualmente entre todas as personagens da história. Como os números em jogo pressupõem uma divisão inexata (10 biscoitos para 3 personagens), tais entrevistados sugeriram guardar o décimo biscoito para uma outra ocasião ou dividi-lo em três pedaços, demonstrando uma preocupação com a precisão da divisão igual: "Ela deve dar três para cada uma para elas ficaram iguais. Aí, sobraria três para ela e sobraria um. Aí, esse um ela pode guardar e comer no outro dia (...). Ou, então, ela dividiria um em três pedacinhos" (Joana, 9; 7). Outros participantes já indicaram a mesma quantidade de biscoitos para as duas personagens e um biscoito a mais para o dono do pacote: "Vou fazer a conta certa senão a minha professora de matemática me mata. Ele daria três para cada um e ficaria com quatro para ele” (Breno, 12; 5). E alguns poucos entrevistados não se preocuparam em estabelecer uma divisão clara do lanche, mas em colocá-lo disponível para ambas as personagens: "Os três devem se sentar numa mesa, aí, ir comendo, se distraindo" (Leonardo, 12;8). Reservadas as diferenças citadas, em todas as 
respostas dessa categoria, a intensidade da ação generosa não varia em função da possibilidade de retribuição. Entendamos, agora, o porquê (Tabela 12) ${ }^{20}$.

Tabela 12

Influência da possibilidade de retribuição na intensidade da ação generosa: distribuição conforme a idade das justificativas dos participantes que decidiram pela divisão igual.

\begin{tabular}{|c|c|c|c|c|c|c|c|c|}
\hline \multirow{2}{*}{ Justificativa } & \multicolumn{2}{|c|}{6 anos } & \multicolumn{2}{|c|}{9 anos } & \multicolumn{2}{|c|}{12 anos } & \multicolumn{2}{|c|}{ Geral } \\
\hline & $\mathrm{N}^{\circ}$ & $\%$ & $\mathrm{~N}^{\circ}$ & $\%$ & $\mathrm{~N}^{\circ}$ & $\%$ & $\mathrm{~N}^{\circ}$ & $\%$ \\
\hline $\begin{array}{l}\text { Circunstâncias de quem precisava } \\
\text { de ajuda }\end{array}$ & 5 & 38,5 & 3 & 25,0 & 6 & 42,9 & 14 & 35,9 \\
\hline Um erro não justifica o outro & 0 & 0,0 & 0 & 0,0 & 3 & 21,4 & 3 & 7,7 \\
\hline $\begin{array}{l}\text { Irrelevância da ausência de } \\
\text { retribuição }\end{array}$ & 0 & 0,0 & 0 & 0,0 & 3 & 21,4 & 3 & 7,7 \\
\hline Amizade & 3 & 23,1 & 4 & 33,3 & 2 & 14,3 & 9 & 23,1 \\
\hline Para evitar briga & 4 & 30,8 & 3 & 25,0 & 1 & 7,1 & 8 & 20,5 \\
\hline Justiça & 1 & 7,7 & 2 & 16,7 & 3 & 21,4 & 6 & 15,4 \\
\hline Outros & 0 & 0,0 & 2 & 16,7 & 3 & 21,4 & 5 & 12,8 \\
\hline
\end{tabular}

Muitos participantes que decidiram pela divisão igual fizeram uso das mesmas justificativas utilizadas na questão anterior. Basta notar que as quatro primeiras categorias da Tabela 12 já estavam presentes na Tabela 11.

As circunstâncias de quem precisava de ajuda continuam prevalecendo entre os critérios apresentados pelos entrevistados (35,9\% daqueles que optaram pela divisão igual): "Porque eles estavam tristes, a barriga deles estava roncando e não havia comida para eles comerem" (Vitor, 6; 9). Aqui, não há grande diferença entre as porcentagens relativas às faixas etárias estudadas, mas as justificativas dessa categoria de alguns participantes de 9 e 12 anos nos remetem à justiça distributiva, mais especificamente à equidade: "Porque ela não retribui, mas ela também está com fome, ela também está passando pela mesma coisa que a outra. Então, eu acho que ela deveria dar a mesma quantidade de biscoitos para as duas" (Isadora, 12; 7). Vejam que Isadora não se importa com a retribuição que certamente não virá, mas com as circunstâncias particulares de cada personagem. Como, na situação apresentada, as

\footnotetext{
${ }^{20}$ Vale saber que $20,5 \%$ dos participantes que decidiram pela divisão igual apresentaram mais de uma razão para suas respostas, por isso o número total de justificativas é superior à quantidade de entrevistados dessa categoria.
} 
circunstâncias são iguais (ambas estão com fome e sem comida), a divisão do lanche também deve ser igual. Mais uma vez, os critérios utilizados pelos mais velhos vão além da simpatia e, entre eles, encontramos a noção de justiça.

A argumentação um erro não justifica o outro, mais uma vez, só aparece entre os participantes de 12 anos que decidiram pela divisão igual (21,4\%): "Não interessa. Se ele é o mais "pão duro" da escola, eu tenho que ser "pão duro" com ele? Não é assim. Tem que dar a mesma quantidade para os dois. Você não deve fazer igual ao outro" (Pedro, 12; 9). A irrelevância da ausência de retribuição também é utilizada como justificativa por $21,4 \%$ dos entrevistados mais velhos que sugeriram a divisão igual: "Porque eu não daria biscoito para ela esperando que ela retribuísse o que eu fiz. Por isso. Eu não estava dando biscoito para ela retribuir o que eu fiz" (Amanda, 12; 6). E a amizade foi uma outra justificativa utilizada para a divisão igual do lanche, indicada aqui por participantes de todas as idades:

A gente não tem que repartir a amizade, como eu falei aqui no começo, não tem que dar uma porcentagem para um, e outra parte para outro. Você não quer ter nenhuma inimizade com ninguém, você dá do jeito que a sua amizade é, não do jeito que essa pessoa retribui ou não (Leonardo, 12; 8).

Uma outra categoria comum a todas as idades pesquisadas foi: para evitar briga, apresentada por $20,5 \%$ dos participantes que decidiram pela divisão igual. "Para não brigar. Senão, vai dar briga, aí, uma pode empurrar a outra" (Carolina, 6; 11). A possibilidade de ocorrer uma briga caso a divisão do lanche não fosse realizada de forma igualitária pressupõe uma certa reivindicação por parte da personagem que, supostamente, receberia menos biscoitos. Esta, na opinião desses entrevistados, não só exigiria a partilha do lanche como a divisão igual do pacote de biscoitos. Mas se, conforme já vimos, uma ação generosa não corresponde a uma exigência social, como poderia alguém reivindicá-la? Tal particularidade da generosidade não parece ter sido considerada nesse tipo de justificativa, que decresce com o avanço da idade.

A justiça é utilizada como argumento por $15,4 \%$ dos participantes que decidiram pela divisão igual do pacote de biscoitos: “(...) porque, senão, não vai ser justo... Porque, assim, seria justo. Para todo mundo ficar com a mesma quantidade” (Joana, 9; 7). Mais uma vez, é da justiça distributiva que falam tais participantes. Embora as porcentagens relativas a essa categoria aumentem com o avanço da idade, não é a sua forma mais evoluída que encontramos aqui, já que o igualitarismo parece prevalecer sobre qualquer outra preocupação. 
$\mathrm{Na}$ Figura 7, vimos que uma minoria dos participantes decidiu pela divisão desigual do lanche: "Aí, eu acho que ele teria que dar biscoitos para os dois, mas menor quantidade para o cara que é 'pão duro'... Três para aquele que retribui e dois para aquele que não retribui", (Edgar, 9; 7). Todos esses participantes apresentaram como justificativa a ausência de retribuição da personagem "pão duro", o que só confirma a influência da possibilidade de retribuição em seus juízos acerca da intensidade da ação generosa para com o outro. Alguns participantes que indicaram a divisão desigual $(21,4 \%)$ também apresentaram a justificativa para aprender a retribuir.

Conhecidos e discutidos os resultados referentes às três histórias, vamos às conclusões que pudemos chegar com o estudo 2.

\subsection{Conclusões}

Quando nos propomos a estudar o tema da generosidade e gratidão, fizemos a hipótese de que nossos participantes indicariam, pelo menos, o simples agradecimento como reação a um ato generoso. E, otimistas, pensamos também na possibilidade das crianças, inclusive as mais novas, mencionarem algum tipo de retribuição como resposta a uma manifestação de generosidade. Conjeturamos, então, que o retorno material ou a recompensa com uma ação concreta prevaleceria nos juízos das crianças mais novas, e a demonstração verbal do reconhecimento de uma dívida para com o outro compareceria apenas nos juízos dos entrevistados mais velhos.

A partir dos dados relativos à primeira história, pudemos verificar que, conforme nossa hipótese, o emprego da fórmula verbal "obrigado", que nos remete à polidez, aparece em todas as faixas etárias, cuja predominância entre as crianças de 6 anos merece destaque. Nessa idade, a polidez prima pela exclusividade enquanto que, entre os entrevistados de 9 e 12 anos, a "pequena virtude" vem, na maioria das vezes, associada a algum tipo de retribuição. O retorno material e a recompensa com uma ação concreta também são mencionados pelas crianças mais novas, mas, diferente do que supúnhamos, não são os maiores destaques entre os tipos de agradecimento e/ ou retribuição sugeridos por elas. A recompensa com uma ação concreta ganha evidência entre os participantes de 9 e 12 anos, mas, nessas faixas etárias, a recompensa material inexiste, e as formas de retribuir ao outro também caminham em direção a abstrações mais amplas. A moral da reciprocidade e a amizade, por exemplo, comparecem 
nas retribuições que sugerem. A demonstração verbal de reconhecimento do que lhe foi feito por outrem praticamente não aparece entre as crianças mais novas e é citada por parte dos participantes mais velhos.

Se nossa hipótese perde força com os resultados relativos à primeira história, sua pertinência se torna mais clara com os dados obtidos a partir da segunda história utilizada neste estudo. Se a recompensa material perde espaço para a polidez nas sugestões espontâneas de agradecimento e/ ou retribuição dos participantes mais novos, ganha evidência na faixa etária de 6 anos quando comparada exclusivamente à demonstração verbal de reconhecimento do que foi feito por outrem. Dos participantes mais novos que atribuíram maior valor a um dos dois tipos de retribuição, a grande maioria indicou a recompensa material. E aqueles que conferiram maior importância à demonstração verbal de reconhecimento destacaram apenas o simples "obrigado" do discurso de agradecimento, o que nos leva a crer que, mais uma vez, é a polidez que está em jogo em suas respostas. Em resumo, podemos afirmar que é o aspecto exterior e material que prevalece nos juízos dos participantes de 6 anos. As crianças mais novas ora ressaltam o aspecto concreto da retribuição, ora se referem à materialidade das regras da polidez, ainda exteriores à consciência. Assim, ora visualizamos a incipiência de suas ferramentas intelectuais, ora nos deparamos com a interpretação ao pé da letra, característica da heteronomia infantil.

Quanto aos participantes mais velhos, aqueles que atribuem maior valor a um dos dois tipos de retribuição, em sua maioria, escolhem a demonstração verbal de reconhecimento. Vimos que essa retribuição pressupõe uma avaliação das intenções do generoso, imprescindível no ciclo completo que conduz à gratidão propriamente dita. Não pretendemos dizer com isso que a recompensa material, indicada pelas crianças mais novas, não possa ser uma autêntica expressão da virtude. Na primeira história, por exemplo, encontramos, nas variadas retribuições sugeridas pelas crianças pequenas, referências a um reconhecimento dos custos envolvidos na ação generosa, também fundamental na manifestação da gratidão. A ponderação dos custos da generosidade manifestada aparece novamente na maioria das justificativas de retribuição de todas as faixas etárias pesquisadas, o que nos permite supor que também há gratidão nas formas de recompensa apresentadas pelas crianças de 6 anos. $\mathrm{O}$ que não fica claro nessas formas de recompensa é se a intencionalidade do generoso é levada em consideração e, consequetemente, se as mesmas representam de fato uma dívida para com outrem. Como a criança mais nova confere maior importância aos efeitos de um ato do que à intenção de seu autor, é provável que ela seja mais grata à ação generosa que lhe causou alegria do que àquele que, intencionalmente, manifestou a generosidade. Talvez ainda não 
compareça, nesses discursos infantis, a gratidão propriamente dita, mas uma concepção mais elementar da virtude, o que nos leva a admitir um desenvolvimento da mesma ao longo da infância.

Se alguns dados indicam variações de respostas sobre retribuição à generosidade nas diferentes faixas etárias, outros resultados não sinalizam grandes mudanças evolutivas nos raciocínios infantis sobre o tema. Quando investigamos sobre a obrigatoriedade de um agradecimento e/ ou retribuição a uma ação generosa, encontramos uma predominância da resposta negativa em todas as idades. A criança mais nova não só entende que aquele que manifesta a generosidade não tem o dever de assim agir como também já compreende que o mesmo não tem o direito de exigir agradecimento e/ ou retribuição de quem recebe a benesse. Sua concepção sobre a virtude, portanto, parece ser ainda mais rica do que supúnhamos até então.

Verificamos, por fim, que a possibilidade de retribuição não exerce qualquer interferência nos juízos sobre a generosidade da grande maioria dos participantes de todas as idades pesquisadas. E suas decisões sobre a intensidade da ação generosa a ser realizada também não tendem a ser influenciadas pela possibilidade de retorno do outro.

Em poucas palavras, constatamos, neste estudo, que, para nossos participantes, a retribuição a uma ação generosa não está atrelada a uma exigibilidade exterior. Embora desprovida de obrigatoriedade, é indicada e admirada, nas suas variadas formas, pelos entrevistados. Essa indicação e admiração, todavia, não fazem da retribuição um critério que os leve a agir generosamente. Como no estudo anterior, é a simpatia que ganha evidência entre as justificativas apresentadas pelas crianças mais novas. O mesmo sentimento também inspira a decisão pela generosidade de nossos participantes mais velhos, mas divide espaço com princípios de reciprocidade e justiça na última faixa etária do estudo. 


\section{CONSIDERAÇÕES FINAIS}

Como pôde ser visto nos capítulos anteriores, dedicamos nossa tese de doutorado ao estudo da generosidade, já iniciado durante o mestrado. Aqui, nos debruçamos sobre dois novos temas relativos à virtude. O primeiro deles diz respeito a uma contraposição entre a generosidade e a justiça (para consigo mesmo), e o segundo se refere à retribuição à ação generosa, que nos remete, em parte, à gratidão. Vejamos agora como os resultados e conclusões desta pesquisa se articulam aos estudos anteriores dedicados à gênese da generosidade na criança.

Vimos que Piaget (1932/1994), em algumas passagens de seu ensaio sobre a moralidade infantil, não só incluía a generosidade no universo moral da criança como já destacava a sua relevância psicológica na construção da moralidade. Os resultados de algumas pesquisas sobre essa virtude, conforme mostramos anteriormente, nos levam a concordar com o autor.

Em um de nossos estudos sobre a generosidade, verificamos que a ação generosa já é valorizada pela criança mais nova, mesmo quando a manifestação da virtude implica uma privação voluntariamente imposta (Vale, 2006; Vale \& Alencar, 2008a). Outras pesquisas sobre a generosidade mostram que a criança pequena não só compreende essa virtude como é capaz de diferenciar a sua falta de transgressões claramente morais e, portanto, merecedoras de punição (La Taille et al., 1998; Vale, 2006; Vale \& Alencar, 2008b). Em nossa pesquisa de doutorado, verificamos que as crianças mais novas não atribuem obrigatoriedade ao agradecimento e/ ou retribuição a uma manifestação de generosidade. Tal resultado nos leva a afirmar que a concepção que a criança pequena tem sobre a virtude é ainda mais rica do que supúnhamos até então: ela não só compreende que aquele que manifesta a generosidade não tem o dever de assim agir como também entende que o mesmo não tem o direito de exigir agradecimento e/ ou retribuição de quem recebe a benesse.

De acordo com a pesquisa que aqui desenvolvemos e outras pesquisas sobre o tema encontradas na literatura (Mileski, 2010; Castro et al., 2011), a retribuição à manifestação de generosidade, embora desprovida de obrigatoriedade, é indicada e admirada, nas suas variadas formas, pelas crianças mais novas. Essa indicação e admiração, todavia, não fazem da retribuição um critério que as leve a agir generosamente, nos mostrando, assim, sinais de autonomia nos juízos relativos à generosidade desde a mais tenra infância. Compreendida de forma mais autônoma pela criança pequena, a generosidade não só está presente no universo moral infantil como possui relevância psicológica na gênese da moralidade, abrindo o 
caminho para a construção do ideal de justiça (La Taille, 2000, 2006a). Vamos às pesquisas que alentam tais afirmações.

Os estudos de Eisenberg (1979) mostram que as atitudes pró-sociais, que nos remetem à generosidade, são mais precoces nas crianças do que os comportamentos relacionados à justiça. Outras pesquisas indicam que as crianças mais novas consideram que alguém que age generosamente é moralmente mais admirável do que quem segue uma regra justa (La Taille et al., 1998) e tendem a optar por ações inspiradas pela generosidade mesmo quando lhes é apresentada uma situação de injustiça (La Taille, 2006b). Além disso, as crianças tendem a atribuir sentimentos negativos a quem falta com a generosidade, mas não o fazem quando se trata de um ato injusto (La Taille, 2006a). Todos esses resultados nos levam a afirmar que a generosidade é melhor integrada à consciência moral do que a justiça no início da gênese da moralidade na criança (La Taille, 2006a). Em nossa pesquisa de doutorado, verificamos que nem mesmo a justiça para consigo mesmo é privilegiada em detrimento da generosidade nos juízos das crianças mais novas. Diante de situações em que uma ação generosa para com o outro implica em uma injustiça para consigo mesmo, as crianças pequenas tomam suas decisões com argumentos que nos remetem à generosidade.

Sabemos que o início do desenvolvimento moral infantil é marcado por uma obediência cega à figura de autoridade. Mas a generosidade, como já bem entendem as crianças mais novas, não está atrelada às imposições do adulto. Mesmo assim, a virtude é valorizada e privilegiada pela criança pequena em detrimento da satisfação de um interesse próprio e da justiça, mesmo da justiça para consigo mesmo. A vida moral infantil parece, portanto, ser mais rica e complexa, não se restringindo a relações de coação. Ao lado do amor pelos pais e do medo da punição, outros sentimentos comparecem no despertar do senso moral. Entre eles, destacamos a simpatia, uma capacidade humana de comover-se com os estados afetivos alheios (La Taille, 2006a). A generosidade está mais relacionada a essa sensibilidade da criança do que à sua disposição para obedecer às ordens de uma autoridade. É inspirada pela simpatia que essa virtude é compreendida de forma mais autônoma pela criança pequena, ocupando, assim, um lugar diferenciado no universo moral infantil.

Nossas pesquisas sobre a generosidade confirmam a íntima relação do sentimento de simpatia com essa virtude. Em todos os estudos que compõem nossa dissertação de mestrado, as condições de quem precisava de ajuda são mencionadas por crianças de todas as faixas etárias para justificarem suas decisões pela ação generosa para com o outro (Vale, 2006; Vale \& Alencar, 2008a; Vale \& Alencar, 2008b; Vale \& Alencar, 2009; Vale \& Alencar, no prelo). Essa comoção com o sofrimento alheio também pôde ser constatada em nossos estudos do 
doutorado. Com porcentagens altas em todas as faixas etárias pesquisadas aqui, esse tipo de argumentação predomina na menor idade e decresce nas idades seguintes. Tal resultado nos mostra, mais uma vez, que é mesmo a simpatia que inspira as crianças pequenas a decidirem pela manifestação da virtude. Essa sensibilidade para com outrem também interfere nos juízos das crianças mais velhas, mas, no transcurso do desenvolvimento, princípios de reciprocidade e justiça também passam a regular as decisões que culminam na generosidade.

Inspirada pela simpatia, a criança já apresenta, desde cedo, sinais de autonomia ao pensar na generosidade, mas isso não significa que ela já tenha uma compreensão plenamente autônoma da virtude. Os resultados de algumas de nossas pesquisas nos mostram mudanças evolutivas nos raciocínios infantis sobre alguns aspectos atinentes à generosidade e nos permitem, portanto, admitir uma gênese dessa virtude na criança.

Em um de nossos estudos, ao contrapormos a generosidade à obediência a uma autoridade, encontramos uma predominância da decisão pela obediência na faixa etária de 7 anos e uma prevalência da generosidade na faixa de idade de 13 anos (Vale, 2006; Vale \& Alencar, no prelo). A ausência de vínculo influencia os juízos relativos à generosidade das crianças de 7 e 10 anos, e a inimizade tende a interferir nas decisões dos participantes de todas as idades pesquisadas, o que nos leva a afirmar que, embora haja modificações ao longo do desenvolvimento sobre o tema em questão, aos 13 anos, ainda não encontramos juízos plenamente autônomos a respeito dessa virtude (Vale, 2006; Vale \& Alencar, 2009).

Vimos que a criança pequena já apresenta sinais de autonomia em seus juízos sobre agradecimento e/ ou retribuição a uma ação generosa, mas aqui e em outras pesquisas encontradas na literatura da área (Freitas et al., 2009a, 2009b; Pieta, 2009), também constatamos mudanças evolutivas nos raciocínios infantis sobre o tema. Em nossa pesquisa de doutorado, verificamos que as crianças mais novas ora ressaltam o aspecto concreto da retribuição, ora se referem à materialidade das regras da polidez, ainda exteriores à consciência. Assim, ora visualizamos a incipiência de suas ferramentas intelectuais, ora nos deparamos com características da heteronomia infantil em seus juízos sobre agradecimento e/ ou retribuição a uma manifestação de generosidade. Entre as crianças mais velhas, é a demonstração verbal de reconhecimento que prevalece quando comparada exclusivamente à recompensa material. Essa forma de retribuição pressupõe uma avaliação das intenções daquele que lhe foi generoso, imprescindível no ciclo completo que conduz a uma outra virtude: a gratidão. Como a criança mais nova ainda confere maior importância aos efeitos de um ato do que à intenção de seu autor (Piaget, 1932/1994), parece-nos válido afirmar que não é a gratidão propriamente dita que comparece em seus discursos, mas uma concepção mais 
elementar da virtude, o que nos leva a considerar um desenvolvimento da mesma ao longo da infância. Os resultados de uma última pesquisa nos indicam que estamos na direção certa.

Enquanto crianças de 5-6 anos atribuem sentimentos intra-individuais àquele que foi beneficiado com um ato de generosidade, crianças de 7-8 anos e, principalmente, de 11-12 anos atribuem sentimentos interindividuais ao mesmo (Freitas et al., 2009a, 2009b). Antes dos 7 anos, não há relação entre o sentimento positivo de quem foi contemplado com uma ação generosa e aquele que manifestou a benesse, ou seja, não há gratidão propriamente dita. A partir dessa idade e, principalmente, aos 11-12 anos, há uma valorização positiva do generoso e, portanto, uma maior aproximação da virtude gratidão.

Terminamos aqui nossa articulação entre as pesquisas encontradas na literatura da área, nossos estudos do mestrado e as contribuições inéditas desta tese. A seguir, apresentamos um quadro geral com todos esses trabalhos, incluindo os resultados e conclusões referentes a cada tema investigado (Figura 8$)^{21}$.

\begin{tabular}{|c|c|c|}
\hline Temas investigados & Resultados & Conclusões \\
\hline $\begin{array}{l}\text { Generosidade e } \\
\text { justiça }\end{array}$ & $\begin{array}{l}\text { As atitudes pró-sociais, que nos remetem à } \\
\text { generosidade, são mais precoces nas } \\
\text { crianças do que comportamentos } \\
\text { relacionados à justiça (Eisenberg, 1979); } \\
\text { As crianças de } 6 \text { anos consideram que } \\
\text { alguém que age generosamente é } \\
\text { moralmente mais admirável do que quem } \\
\text { segue uma regra justa (La Taille et al., } \\
\text { 1998); } \\
\text { As crianças de } 6 \text { anos não atribuem } \\
\text { sentimentos positivos a quem falta com a } \\
\text { generosidade, mas o fazem quando se trata } \\
\text { de um ato injusto, enquanto as crianças de } 9 \\
\text { anos não atribuem sentimentos positivos } \\
\text { em ambos os casos (La Taille, } 2006 \text { a); } \\
\text { As crianças de } 6 \text { anos tendem a optar por } \\
\text { ações inspiradas pela generosidade mesmo } \\
\text { quando lhes é apresentada uma situação de } \\
\text { injustiça, enquanto as crianças de } 9 \text { anos } \\
\text { decidem pelo ato de justiça na mesma } \\
\text { situação (La Taille, 2006b); }\end{array}$ & $\begin{array}{l}\text { A generosidade é virtude presente no início } \\
\text { da gênese da moralidade e melhor integrada } \\
\text { à consciência moral do que a justiça nessa } \\
\text { mesma fase do desenvolvimento, mesmo } \\
\text { em se tratando da justiça para consigo } \\
\text { mesmo. }\end{array}$ \\
\hline
\end{tabular}

${ }^{21}$ Vale ressaltar que, tendo como foco os objetivos desta tese, nos ativemos aqui às pesquisas que abordam a generosidade em um contexto psicogenético. Outros estudos sobre a virtude podem ser conferidos nos capítulos anteriores deste trabalho. 


\begin{tabular}{|c|c|c|}
\hline & $\begin{array}{l}\text { Diante de um conflito entre a generosidade } \\
\text { e a justiça (para consigo mesmo), os juízos } \\
\text { das crianças de } 6 \text { anos nos remetem mais à } \\
\text { generosidade, e os critérios utilizados pelos } \\
\text { mais velhos estão atrelados à noção de } \\
\text { justiça (Vale, 2012). }\end{array}$ & \\
\hline $\begin{array}{l}\text { Generosidade } \mathrm{X} \\
\text { satisfação do próprio } \\
\text { interesse }\end{array}$ & $\begin{array}{l}\text { Participantes de } 7,10 \text { e } 13 \text { anos tendem a } \\
\text { decidir pela generosidade em detrimento da } \\
\text { satisfação de um interesse próprio (Vale, } \\
\text { 2006; Vale \& Alencar, 2008a). }\end{array}$ & $\begin{array}{l}\text { A generosidade já é valorizada pela criança } \\
\text { pequena e assim tende a permanecer ao } \\
\text { longo do desenvolvimento, mesmo quando } \\
\text { a manifestação da virtude implica uma } \\
\text { privação voluntariamente imposta. }\end{array}$ \\
\hline $\begin{array}{l}\text { Generosidade X } \\
\text { obediência à } \\
\text { autoridade }\end{array}$ & $\begin{array}{l}\text { Há uma predominância da decisão pela } \\
\text { obediência na faixa etária de } 7 \text { anos e uma } \\
\text { prevalência da generosidade na faixa de } \\
\text { idade de } 13 \text { anos. (Vale, 2006; Vale \& } \\
\text { Alencar, no prelo). }\end{array}$ & $\begin{array}{l}\text { A generosidade é valorizada pela criança } \\
\text { pequena desde que não seja contraposta à } \\
\text { ordem de uma autoridade. O mesmo não } \\
\text { acontece com os adolescentes, que tendem a } \\
\text { manter a decisão pela virtude mesmo } \\
\text { quando a sua manifestação vai de encontro } \\
\text { à regra estabelecida por um adulto. }\end{array}$ \\
\hline $\begin{array}{l}\text { Generosidade para } \\
\text { com amigo, } \\
\text { desconhecido e } \\
\text { inimigo }\end{array}$ & $\begin{array}{l}\text { Participantes de } 7,10 \text { e } 13 \text { anos decidem } \\
\text { pela generosidade nas situações de amizade } \\
\text { e ausência de vínculo. As crianças de } 7 \text { e } 10 \\
\text { anos, contudo, julgam que a ação generosa } \\
\text { para com um amigo deve ser mais intensa } \\
\text { do que para com um desconhecido. Na } \\
\text { situação de inimizade, os participantes das } \\
\text { três idades decidem pela ausência de } \\
\text { generosidade (Vale, 2006; Vale \& Alencar, } \\
\text { 2009). }\end{array}$ & $\begin{array}{l}\text { A ausência de vínculo influencia os juízos } \\
\text { relativos à generosidade das crianças de } 7 \text { e } \\
10 \text { anos, e a inimizade tende a interferir nas } \\
\text { decisões dos participantes de todas as } \\
\text { idades pesquisadas, o que nos leva a admitir } \\
\text { que, embora haja mudanças evolutivas } \\
\text { sobre o tema em questão, aos } 13 \text { anos, ainda } \\
\text { não encontramos juízos plenamente } \\
\text { autônomos a respeito da virtude. }\end{array}$ \\
\hline $\begin{array}{l}\text { Generosidade e } \\
\text { punição }\end{array}$ & $\begin{array}{l}\text { As crianças de } 6 \text { anos dispensam a punição } \\
\text { para quem falta com a generosidade e } \\
\text { alegam que a sanção deve cair apenas sobre } \\
\text { aquele que cometeu um ato injusto (La } \\
\text { Taille et al., 1998); } \\
\text { Participantes de } 7,10 \text { e } 13 \text { anos indicam a } \\
\text { conversa, e não o castigo, como } \\
\text { consequência da ausência de generosidade } \\
\text { (Vale, 2006; Vale \& Alencar, 2008b); }\end{array}$ & $\begin{array}{l}\text { A criança pequena já diferencia ações } \\
\text { generosas de atos de justiça, } \\
\text { compreendendo que uma manifestação de } \\
\text { generosidade não está atrelada a uma } \\
\text { exigibilidade exterior. }\end{array}$ \\
\hline $\begin{array}{l}\text { Generosidade e } \\
\text { retribuição }\end{array}$ & $\begin{array}{l}\text { Crianças de } 6,9 \text { e } 12 \text { anos não atribuem } \\
\text { obrigatoriedade ao agradecimento e/ ou à } \\
\text { retribuição a uma manifestação de } \\
\text { generosidade (Vale, 2012); } \\
\begin{array}{l}\text { Crianças de } 6,9 \text { e } 12 \text { anos indicam e } \\
\text { admiram o agradecimento e/ ou a } \\
\text { retribuição a uma manifestação de }\end{array}\end{array}$ & $\begin{array}{l}\text { A compreensão da criança pequena sobre a } \\
\text { generosidade é ainda mais rica do que } \\
\text { supúnhamos até então: ela não só entende } \\
\text { que aquele que manifesta a virtude não tem } \\
\text { o dever de assim agir como também já } \\
\text { compreende que o mesmo não tem o direito } \\
\text { de exigir agradecimento e/ ou retribuição de } \\
\text { quem recebe a benesse. } \\
\text { Embora desprovida de obrigatoriedade, a } \\
\text { retribuição é indicada e admirada, nas suas } \\
\text { variadas formas, pelas crianças de } 6,9 \text { e } 12\end{array}$ \\
\hline
\end{tabular}




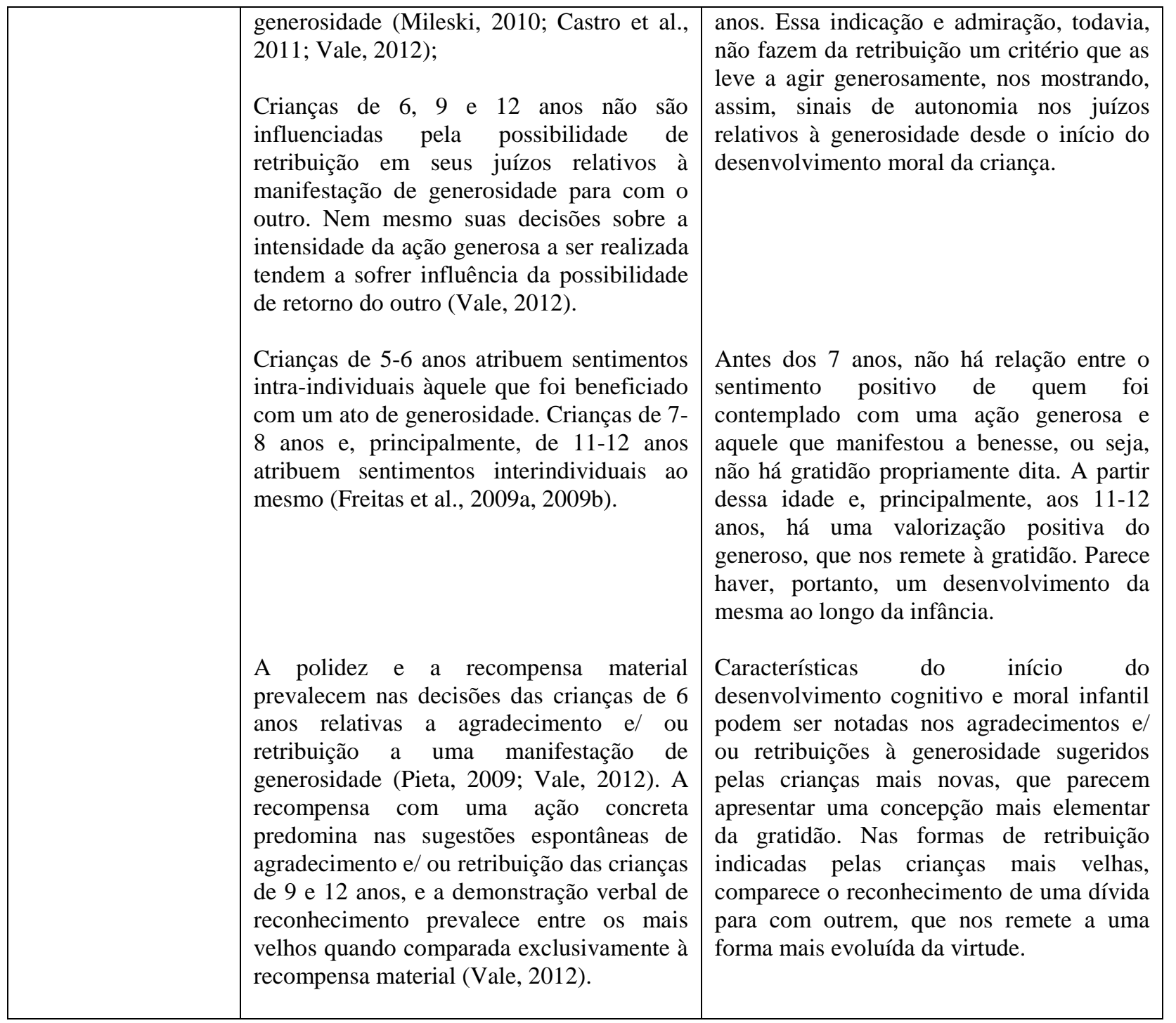

Figura 8. Pesquisas que abordam a generosidade em um contexto psicogenético.

Eis aqui um mapeamento dos estudos que, de alguma forma, abordam a generosidade no que tange, especificamente, a suas relações com o desenvolvimento moral. Sabemos, com Piaget (1932/1994), que a justiça é a mais racional de todas as virtudes e não pretendemos desprezá-la como noção incontornável da moralidade. O que esse mapeamento nos mostra é que o universo moral infantil não se restringe ao binômio direito/ dever. A generosidade não só faz parte da vida moral da criança pequena como, compreendida de forma mais autônoma desde cedo, desempenha um importante papel na construção da justiça, essa virtude maior, sem a qual, conforme Smith (1759/1999), uma sociedade ruiria. Se uma educação moral é possível, parece-nos pertinente, portanto, incluir a generosidade nas propostas pedagógicas contemporâneas. E se, com Piaget (1931/1998), devemos partir da psicologia infantil para 
pensar em estratégias pedagógicas, aqui está um possível ponto de partida para propostas de educação que contemplem a generosidade. 


\section{REFERÊNCIAS}

Aristóteles (1992). Ética a nicômacos (2ª ed., M. G. Kury, Trad.). Brasília: Universidade de Brasília (Trabalho original publicado em 384-322 a.c.).

Baumgarten-Tramer, F. (1938). "Gratefulness" in children and young people. Journal of Genetic Psychology, 53, 53-66.

Bennett, W. J. (1995). O livro das virtudes. Rio de Janeiro: Nova Fronteira.

Bonnie, K. E. \& de Wall, F. B. M. (2004). Primate social reciprocity and the origin of gratitude. In R. A. Emmons \& M. E. McCullough (Orgs.), The psychology of gratitude (pp. 213-229). New York: Oxford University Press.

Brasil (1997). Ministério da Educação e Cultura. Parâmetros Curriculares Nacionais. Brasília: Secretaria de Educação Fundamental.

Campbell, R. \& Christopher, J. (1996). Moral development theory: a critique of its kantian presupositions. Development Review, 16 (1), 1-47.

Castro, F. M. P.; Rava, P. G. S.; Hoefelmann, T. B.; Pieta, M. A. M. \& Freitas, L. B. L. (2011). Deve-se retribuir? Gratidão e dívida simbólica na infância. Estudos de Psicologia, 16 (1), 75-82.

Cecconello, A. M. \& Koller, S. H. (2000). Competência social e empatia: um estudo sobre resiliência com crianças em situação de pobreza. Estudos de Psicologia, 5 (1), 71-93.

Comte-Sponville, A. (1997). Pequeno tratado das grandes virtudes (E. Brandão, Trad.). São Paulo: Martins Fontes (Trabalho original publicado em 1995).

Cortella, M. S. \& La Taille, Y. (2005). Nos labirintos da moral. Campinas: Papirus.

Delval, J. (2002). Introdução à prática do método clínico: descobrindo o pensamento das crianças (F. Murad, Trad.). Porto Alegre: Artmed. 
Dias, A. C. F. (2002). Estudo psicológico sobre o lugar das virtudes no universo moral aos 7 anos de idade: as crianças da $1^{a}$ série discutem coragem e generosidade. Dissertação de Mestrado não-publicada, Instituto de Psicologia, Universidade de São Paulo, São Paulo.

Eisenberg, N. (1979). Development of children's prosocial judgment. Developmental psychology, 15 (2), 129-137.

Flanagan, O. (1996). Psychologie morale et éthique. Paris: PUF.

Freitag, B. R. (2002). Itinerários de Antígona: a questão da moralidade. Campinas: Papirus.

Freitas, L. B. L.; Silveira, P. G. \& Pieta, M. A. M. (2009a). Um estudo sobre o desenvolvimento da gratidão na infância. Revista Interamericana de Psicologial Interamerican Journal of Psychology, 43 (1), 49-56.

Freitas, L. B. L.; Silveira, P. G. \& Pieta, M. A. M. (2009b). Sentimento de gratidão em crianças de 5 a 12 anos. Psicologia em Estudo, 14 (2), 243-250.

Freud, S. (1976). O ego e o id. In Edição Standard das Obras Psicológicas Completas de Sigmund Freud (J. Salomão, Trad., Vol. 19, pp. 13-76). Rio de Janeiro: Imago (Trabalho original publicado em 1923).

Freud, S. (1976). O problema econômico do mazoquismo. In Edição Standard das Obras Psicológicas Completas de Sigmund Freud (J. Salomão, Trad., Vol. 19, pp. 197-212). Rio de Janeiro: Imago (Trabalho original publicado em 1924).

Garcia, A. (2005). Psicologia da amizade na infância: uma revisão crítica da literatura recente. Interação em Psicologia, 9 (2), 285-294.

Garcia, A. \& Pereira, P. C. C. (2008). Amizade na infância: um estudo empírico. PSIC Revista de Psicologia da Vetor Editora, 9 (1), 25-34.

Gilligan, C. (1982). Uma voz diferente (N. C. Caixeiro, Trad.). Rio de Janeiro: Rosa dos Tempos.

Godbout, J. T. (1992). O espírito da dádiva (J. P. Cabrera, Trad.). Lisboa: Instituto Piaget. 
Hoffman, M. (1978). Desenvolvimento moral. In Carmichael (Org.), Psicologia da criança: socialização (pp. 1-170). São Paulo: EDUSP.

Houaiss, A. \& Villar, M. S. (2001). Dicionário Houaiss da língua portuguesa. Rio de Janeiro: Objetiva.

Kant, E. (1980). Fundamentação da metafísica dos costumes. In Os pensadores (Vol.2, pp.101-162), (P. Quintela, Trad.). São Paulo: Abril Cultural (Trabalho original publicado em $1785)$.

Kohlberg, L. (1992). Psicologia del desarrollo moral. Spain: Desclée de Brouwer.

Kohlberg, L., Boyd, D. R. \& Levine, C. (2002). O retorno do estágio 6: seu princípio e ponto de vista moral (W. Settineri, Trad.). In A. M. B. Biaggio (Org.), Lawrence Kohlberg: ética e educação moral (pp. 100-130). São Paulo: Moderna (Trabalho original publicado em 1990).

Koller, S. H. \& Bernardes, N. M. G. (1997). Desenvolvimento moral pró-social: semelhanças e diferenças entre os modelos teóricos de Einsenberg e Kohlberg. Estudos de Psicologia, 2 (2), 223-262.

Laplanche, J. \& Pontalis, J. B. (2001), Vocabulário de Psicanálise (4ª ed., P. Tamen, Trad.) São Paulo: Martins Fontes.

La Taille, Y. (2000). Para um estudo psicológico das virtudes morais. Educação e Pesquisa, $26(1), 109-121$.

La Taille, Y. (2001a). Desenvolvimento moral: a polidez segundo as crianças. Cadernos de Pesquisa, n. 114, 89-119.

La Taille, Y. (2001b). A questão da indisciplina: ética, virtudes e educação. In P. Demo, Y. La Taille \& J. Hoffmann (Orgs.), Grandes pensadores em educação: o desafio da aprendizagem, da formação moral e da avaliação (pp. 67-98). Porto Alegre: Mediação.

La Taille, Y. (2002a). Cognição, afeto e moralidade. In M. K. Oliveira, D. T. R. Souza \& T. C. Rego (Orgs.), Psicologia, educação e as temáticas da vida contemporânea (pp. 135-158). São Paulo: Moderna.

La Taille, Y. (2002b). Vergonha, a ferida moral. Petrópolis: Vozes. 
La Taille, Y. (2006a). A importância da generosidade no início da gênese da moralidade na criança. Psicologia: Reflexão e Crítica, 19 (1), 9-17.

La Taille, Y. (2006b). Moral e ética: dimensões intelectuais e afetivas. Porto Alegre: Artmed.

La Taille, Y. (2007). Desenvolvimento humano: contribuições da psicologia moral. Psicologia USP, 18 (1), 11-36.

La Taille, Y. (2009a). Formação ética: do tédio ao respeito de si. Porto Alegre: Artmed.

La Taille, Y. (2009b). As virtudes segundo os jovens. In Y. La Taille \& M. S. S. Menin (Orgs.), Crise de valores ou valores em crise? (pp. 46-69). Porto Alegre: Artmed.

La Taille, Y., Micelli, A., Domingues, C., Kravosac, D. B., Jamra, F. A., Fiorini, F. P., Bronstein, M. \& Neto, S. O. (1998). As virtudes morais segundo as crianças (Relatório Científico FAPESP não-publicado/1998), Instituto de Psicologia da Universidade de São Paulo, São Paulo.

La Taille, Y., Domingues, C. B., Jamra, F. A., Fiorini, F. P. (1999). As virtudes morais segundo as crianças (Relatório Científico não-publicado/1999), Instituto de Psicologia da Universidade de São Paulo, São Paulo.

La Taille, Y., Souza, L. S. \& Vizioli, L. (2004). Ética e educação: uma revisão da literatura educacional de 1990 a 2003. Educação e Pesquisa, 30 (1), 91-105.

Lobato, M. (1987). A chave do tamanho: fábulas. São Paulo: Círculo do livro.

Lourenço, O. (1991). Is the care orientation distinct from the justice orientation? Some empirical data in ten- to eleven- year- old children. Archives de Psychologie, 59,17-30.

Lourenço, O. M. (2003). Children's appraisals of anti-social acts: a piagetian perspective. British Journal of Developmental Psychology, 21, 19-31.

Mileski, A. Z. (2010). A ingratidão: o juízo moral de crianças de 5 a 12 anos. Dissertação de Mestrado, Universidade Federal do Rio Grande do Sul, Porto Alegre, RS, Brasil. 
Montangero, J. \& Maurice-Naville, D. (1998). Piaget ou a inteligência em evolução (F. Becker \& T. B. I. Marques, Trad.). São Paulo: Artmed (Trabalho original publicado em 1994).

Perron, R. (1991). Les représentations de soi. Toulouse, Privat.

Piaget, J. (s.d.). Introdução: Os problemas e os métodos. In A representação do mundo na criança (pp. 5-28), (R. Fiúza, Trad.). Rio de Janeiro: Record (Trabalho original publicado em 1926).

Piaget, J. (1954). Les relations entre l'affectivité et l'intelligence dans le développement mental del'enfant. Paris: Centre de Documentation Universitaire de la Sorbonne (Paris V).

Piaget, J. (1983). Problemas de Psicologia Genética. In Os pensadores (pp. 209-294), (2ª ed., C. E. A. Di Piero, Trad.). São Paulo: Abril Cultural (Trabalho original publicado em 1972).

Piaget, J. (1994). O juízo moral na criança (2a ed., E. Lenardon, Trad.). São Paulo: Summus (Trabalho original publicado em 1932).

Piaget, J. (1996). Os procedimentos da educação moral (M. S. S. Menin, Trad.). In L. Macedo (Org.), Cinco estudos de educação moral (pp. 2-36). São Paulo: Casa do Psicólogo (Trabalho original publicado em 1930).

Piaget, J. (1998). O espírito de solidariedade e a colaboração internacional. In S. Parrat-Dayan \& A. Tryphon (Orgs.), Sobre a pedagogia (pp. 59-78). São Paulo: Casa do Psicólogo (Trabalho original publicado em 1931).

Piaget, J. (2003). Seis estudos de psicologia (24a ed., M. A. M D’Amorim \& P. Sérgio L. Silva, Trad.). Rio de Janeiro: Forense Universitária (Trabalho original publicado em 1964).

Pieta, M. A. M. (2009). A expressão do sentimento de gratidão: um estudo com crianças $e$ adolescentes escolares de Porto Alegre. Dissertação de Mestrado, Universidade Federal do Rio Grande do Sul, Porto Alegre, RS, Brasil.

Pinheiro, V. P. G. (2009). A generosidade e os sentimentos morais: um estudo exploratório na perspectiva dos Modelos Organizadores do Pensamento. Dissertação de mestrado, Universidade de São Paulo, São Paulo, SP, Brasil.

Ricoeur, P. (1990). Soi-même comme un autre. Paris: Seuil. 
Smith, A. (1999). Teoria dos sentimentos morais. (L. Luft, Trad.). São Paulo: Martins Fontes (Trabalho original publicado em 1759).

Souza, M. T. C. C. (2005). Valorizações afetivas nas representações de contos de fadas: um olhar piagetiano. Boletim de Psicologia, LV (123), 205-232.

Souza, M. T. C. C. (2007). Interpretações de histórias: inteligência e afetividade em ação. Tese de Livre-Docência, Instituto de Psicologia, Universidade de São Paulo, São Paulo, SP, Brasil.

Tognetta, L. R. P. (2003). A construção da solidariedade e a educação do sentimento na escola. Campinas: Mercado das Letras, São Paulo: Fapesp.

Tognetta, L. R. P. (Org.) (2007). Virtudes e educação: o desafio da modernidade. Campinas: Mercado de Letras.

Tognetta, L. R. P. (2009). Perspectiva ética e generosidade. Campinas: Mercado de Letras.

Tognetta, L. R. P. \& Assis, O. Z. M. (2006). A construção da solidariedade na escola: as virtudes, a razão e a afetividade. Educação e Pesquisa, 32 (1), 49-66.

Tognetta, L. R. P. \& La Taille, Y. (2008). A formação de personalidades éticas: representações de si e moral. Psicologia: Teoria e Pesquisa, 24 (2), 181-188.

Tugendhat, E. (1996). Lições sobre ética (Grupo de doutorandos do curso de pós-graduação em Filosofia da Universidade Federal do Rio Grande do Sul, Trad.). Petrópolis: Vozes.

Vale, L. G. (2006). Desenvolvimento moral: a generosidade sob a ótica de crianças e adolescentes. Dissertação de Mestrado, Universidade Federal do Espírito Santo, Vitória, ES, Brasil.

Vale, L. G. \& Alencar, H. M. (2008a). Generosidade versus interesse próprio: juízos morais de crianças e adolescentes. Psicologia: Teoria e Pesquisa, 24 (4), 423-431.

Vale, L. G. \& Alencar, H. M. (2008b). Juízos morais de crianças e adolescentes sobre ausência de generosidade e punição. PSIC - Revista de Psicologia da Vetor Editora, 9 (2), 235-244. 
Vale, L. G. \& Alencar, H. M. (2009). Generosidade para com amigo, desconhecido e inimigo: juízos morais de crianças e adolescentes. Interação em Psicologia, 13 (2), 299-310.

Vale, L. G. \& Alencar, H. M. (no prelo). A generosidade em contraposição à obediência à autoridade: juízos morais de crianças e adolescentes. In C. B. Rossetti \& A. C. Ortega (Orgs.), Cognição, afetividade e moralidade: estudos a partir do referencial teórico de Jean Piaget. São Paulo: Casa do Psicólogo.

Walker, L. J. (1984). Sex differences in the development of moral reasoning: a critical review. Child Development, 55 (3), 677-691.

Waterman, A. (1995). Eudaimonic theory: self-realization and the collective good. In Kurtines (Org.), Moral development: an introduction (pp. 225-278). London: Allyn and Bacon. 
Apêndice A.

Parecer do Comitê de Ética em Pesquisa com Seres Humanos 


\section{UNIVERSIDADE DE SÃO PAULO \\ INSTITUTO DE PSICOLOGIA \\ CEPH - COMITÊ DE ÉTCA EM PESQUISA HUMANA COM SERES HUMANOS}

Registro CEPH No. 2010.036

Título do Projeto: Desenvolvimento moral: pesquisando os juízos das crianças sobre a generosidade

Pesquisadora: Liana Gama do Valle

Orientadora: Yves Joel Jean Marie Rodolpho de La Taille

Departamento/Ärea de concentração: PSA / Psicologia Escolar e do Desenvolvimento Humano

\section{PARECER}

Trata-se de um estudo que visa investigar, em um contexto psicogenético, os juizos das crianças sobre a generosidade. Para tal, serão selecionados 60 alunos de uma escola do Rio de Janeiro na faixa etária de 6 a 12 anos e realizar-se-ão entrevistas individuais de acordo com o método clínico de Piaget, nas quais serão contadas histórias que abordam três dimensões da generosidade: a manifestação da generosidade implica em forte prejuízo pessoal, a retribuição da generosidade manifesta na $1^{\text {a }}$ história e uma situação escolar cotidiana que pode ou não implicar na manifestação de generosidade. A partir das histórias contadas será perguntado aos sujeitos o que eles acham que o personagem de cada história deve fazer na situação em que ele se encontra para avaliar a questão do juízo moral. Todas as entrevistas serão gravadas e ficarão armazenadas em local seguro após o término da pesquisa. Será apresentado à escola o presente projeto de pesquisa, bem como a carta de aprovação do Comitê de Ética. Após a autorização para realização da pesquisa pela escola, os pais dos alunos serão informados sobre a mesma e aqueles que autorizarem que seus filhos participem através da assinatura do Termo de Consentimento Livie e Esclarecido, terão seus filhos entrevistados numa sala da própria escola em horário designado pela mesma para não atrapalhar as atividades escolares cotidianas. $O$ trabalho se mostra atento às questões éticas, as entrevistas não irão causar problemas às crianças e o Termo de Consentimento Livre e Esclarecido deixa claro os objetivos e procedimentos que serão adotados, que as entrevistas serão gravadas, a garantia do sigilo dos participantes, a possibilidade dos mesmos decidirem deixar a pesquisa a qualquer momento do processo, a garantia do anonimato quando da divulgação dos dados, a indicação do local onde serão armazenados os dados coletados após o término da pesquisa, campo para assinatura dos responsáveis pela criança a ser entrevistadas e inclui um contato institucional com a pesquisadora. Solicita-se somente a inclusão da assinatura do pesquisador no Termo de Consentimento Livre e Esclarecido e a entrega de uma via do Termo para os responsáveis pelo participante da pesquisa; e a entrega de cópia da autorização de realização da pesquisa por parte da escola para o Comitê de Ética, assim que a tiver em mãos. Considera-se a pesquisa aprovada.

\section{( $\mathbf{X}$ ) aprovado}

( ) pendente com necessidade de apresentar reformulaçōes para ser aprovado

( ) reprovado 
Apêndice B.

Modelo do pedido de autorização para a escola 
UNIVERSIDADE DE SÃO PAULO

INSTITUTO DE PSICOLOGIA

PROGRAMA DE PÓS-GRADUAÇÃO EM PSICOLOGIA ESCOLAR E DO

DESENVOLVIMENTO HUMANO

Ilmo Sr (Ilma Sra) nome do diretor (a)

Diretor (a) da Escola (nome da escola)

Vimos, por meio desta, solicitar a Vossa Senhoria autorização para a realização da coleta de dados do projeto de pesquisa intitulado Desenvolvimento moral: pesquisando os juízos das crianças sobre a generosidade na Escola (nome da escola). O referido projeto faz parte da tese de doutorado da aluna Liana Gama do Vale, sob a orientação do Prof. Dr. Yves Joel Jean Marie Rodolphe de La Taille.

Encaminhamos, a seguir, alguns dados do projeto e, caso seja necessária alguma informação complementar, estaremos à disposição para quaisquer esclarecimentos.

Contando com a sua colaboração, agradecemos desde já.

Liana Gama do Vale

Aluna de doutorado do PSA

$\mathrm{N}^{\mathrm{o}}$ USP 6325650

\section{Dados de identificação}

Responsável pela coleta de dados: Liana Gama do Vale, aluna regular do Programa de Pós-

Graduação em Psicologia Escolar e do Desenvolvimento Humano (PSA) do Instituto de Psicologia da Universidade de São Paulo (IPUSP).

Contato: (21) 8861-3932/ 2537-1132Ｅ-mail: lianadovale@usp.br

Endereço do Comitê de Ética em Pesquisa com Seres Humanos do IPUSP: Av. Prof. Mello Moraes, 1721, Bloco G, sala 22, Cidade Universitária. São Paulo, SP. Telefone: (11) $3097-$ 0529. 


\section{Objetivo geral da pesquisa}

Investigar os juízos de crianças e adolescentes sobre a generosidade.

\section{Participantes da pesquisa}

Participarão da pesquisa 60 alunos de 6; 9 e 12 anos, igualmente divididos quanto ao sexo e à idade, conforme podemos observar na Tabela A1. Com base nas variáveis mencionadas, os alunos serão selecionados por meio de um sorteio.

Tabela A1

Distribuição dos participantes da pesquisa de acordo com idade e sexo

\begin{tabular}{cccc}
\hline \multirow{2}{*}{ Idade } & & Sexo & \\
\cline { 2 - 4 } & Masculino & Feminino & Total \\
\hline 6 & 10 & 10 & 20 \\
9 & 10 & 10 & 20 \\
12 & 10 & 10 & 20 \\
\hline Total & 30 & 30 & 60 \\
\hline
\end{tabular}

\section{Descrição dos instrumentos e procedimentos da pesquisa:}

Serão realizadas entrevistas individuais, com duração aproximada de 35 minutos. As questões de investigação serão baseadas em histórias que envolvem o tema da generosidade. As entrevistas serão gravadas e, posteriormente, transcritas.

A coleta de dados deverá ser realizada dentro da própria escola. Solicitamos, por gentileza, uma sala vazia para a realização das entrevistas. O horário da coleta será organizado de forma a não prejudicar as atividades escolares.

\section{Compromissos da pesquisadora}

Esclarecemos que os dados obtidos durante a coleta serão guardados de forma segura em nosso arquivo pessoal e serão utilizados exclusivamente para fins de pesquisa. A gravação e a transcrição das entrevistas não comprometerão o anonimato dos participantes, visto que não será atrelado às respostas nenhum tipo de identificação dos entrevistados.

Asseguramos que o aluno poderá desistir de participar da pesquisa em qualquer momento se ele e/ ou seus responsáveis assim o desejarem. 


\section{Benefícios esperados}

Os resultados da pesquisa serão divulgados em congressos, periódicos científicos e em discussões nas escolas, contribuindo, assim, para a ampliação do corpo de conhecimentos que se têm produzido sobre o tema em questão. Esperamos que nosso estudo possa trazer importantes subsídios para propostas de educação moral que contemplem virtudes como a generosidade.

\section{Termo de consentimento}

Prezado (a) Diretor (a),

Caso esteja de acordo com a participação desta escola na presente pesquisa, favor preencher o documento a seguir em duas vias.

$\mathrm{Eu}$, autorizo a participação da escola (nome da escola) no projeto de pesquisa intitulado Desenvolvimento moral: pesquisando os juízos das crianças sobre a generosidade.

Rio de Janeiro: de de 2010. 
Apêndice C.

Modelo do termo de consentimento dos pais ou responsáveis legais 


\section{UNIVERSIDADE SÃO PAULO \\ INSTITUTO DE PSICOLOGIA \\ PROGRAMA DE PÓS-GRADUAÇÃO EM PSICOLOGIA ESCOLAR E DO \\ DESENVOLVIMENTO HUMANO}

Prezado (a) Senhor (a),

Vimos, por meio desta, solicitar a Vossa Senhoria autorização para que seu (sua) filho (a) participe da coleta de dados do projeto de pesquisa intitulado Desenvolvimento moral: pesquisando os juízos das crianças sobre a generosidade. O referido projeto faz parte da tese de doutorado da aluna Liana Gama do Vale, sob a orientação do Prof. Dr. Yves Joel Jean Marie Rodolphe de La Taille.

Encaminhamos, a seguir, alguns dados do projeto e, caso seja necessária alguma informação complementar, estaremos à disposição para quaisquer esclarecimentos.

Contando com a sua colaboração, agradecemos desde já. 


\section{Dados de identificação}

Responsável pela coleta de dados: Liana Gama do Vale, aluna regular do Programa de PósGraduação em Psicologia Escolar e do Desenvolvimento Humano (PSA) do Instituto de Psicologia da Universidade de São Paulo (IPUSP).

Contato: (21) 8861-3932/ 2537-1132Ｅ-mail: lianadovale@usp.br

Endereço do Comitê de Ética em Pesquisa com Seres Humanos do IPUSP: Av. Prof. Mello Moraes, 1721, Bloco G, sala 22, Cidade Universitária. São Paulo, SP. Telefone: (11) $3097-$ 0529.

\section{Objetivo geral da pesquisa}

Investigar os juízos de crianças e adolescentes sobre a generosidade.

\section{Descrição dos instrumentos e procedimentos da pesquisa:}

Serão realizadas entrevistas individuais, com duração aproximada de 35 minutos. As questões de investigação serão baseadas em histórias que envolvem o tema da generosidade. As entrevistas serão gravadas e, posteriormente, transcritas.

A coleta de dados será realizada dentro da própria escola de seu filho. O horário para a realização das entrevistas será organizado de forma a não prejudicar as suas atividades escolares.

\section{Compromissos da pesquisadora}

Esclarecemos que os dados obtidos durante a coleta serão guardados de forma segura em nosso arquivo pessoal e serão utilizados exclusivamente para fins de pesquisa. A gravação e a transcrição das entrevistas não comprometerão o anonimato dos participantes, visto que não será atrelado às respostas nenhum tipo de identificação dos entrevistados.

Asseguramos que a criança poderá desistir de participar da pesquisa em qualquer momento se ela e/ ou seus responsáveis assim o desejarem.

\section{Benefícios esperados}

Os resultados da pesquisa serão divulgados em congressos, periódicos científicos e em discussões nas escolas, contribuindo, assim, para a ampliação do corpo de conhecimentos que se têm produzido sobre o tema em questão. Esperamos que nosso estudo possa trazer importantes subsídios para propostas de educação moral que contemplem virtudes como a generosidade. 


\section{Termo de consentimento}

Prezado (a) Senhor (a),

Caso esteja de acordo com a participação de seu (sua) filho (a) na presente pesquisa, favor preencher o documento a seguir em duas vias.

$\mathrm{Eu}$, (nome do pai, da mãe

ou do responsável), R.G. Órgão Emissor declaro

concordar

que

meu

(minha)

filho

(a)

participe da coleta de

dados do projeto de pesquisa intitulado Desenvolvimento moral: pesquisando os juízos das crianças sobre a generosidade, conforme termos anteriormente discriminados.

Rio de Janeiro: de de 2010. 
Apêndice D.

Protocolos das entrevistas (em CD digitalizado) 
O CD digitalizado abaixo contém os 60 protocolos das entrevistas realizadas durante a coleta de dados. Os arquivos dos protocolos foram distribuídos em três pastas de acordo com as idades dos participantes entrevistados. Assim, temos aqui três pastas referentes às três faixas etárias pesquisadas (6, 9 e 12 anos), cada uma com 20 arquivos. Vale dizer que não transcrevemos as histórias apresentadas aos participantes, apenas as questões referentes a cada instrumento seguidas das respostas dos entrevistados. Durante a leitura das entrevistas, a letra $E$ deve ser entendida como Entrevistador, e a letra $P$, como Participante, cujas respostas foram destacadas com letra em negrito e itálico. Os nomes dos entrevistados apresentados em todos os protocolos são fictícios para não comprometermos o seu anonimato. 